Recsived ty 08

OCT 031990

\title{
Investigation on the Continued Production of the Naval Petroleum Reserves Beyond April 5, 1991
}

September 1990

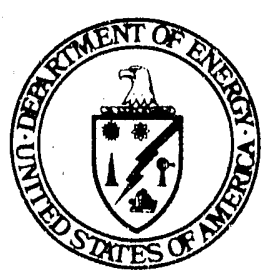

U.S. Depariment of Energy Assistant Secretary, Fossil Energy Office of Petroleum Reserves Washington, D.C. 20585 


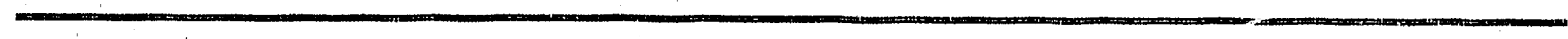

\begin{abstract}
The authority to produce the Naval Petroleum Reserves (NPRs) is due to expire in April 1991, unless extended by Presidential finding. As provided in the Naval Petroleum Reserves Production Act of 1976 (Public Law 94-258), the President may continue production of the NPRs for a period of up to three years following the submission to Congress, at least 180 days prior to the expiration of the current production period, of a report that determines that continued production of the NPRs is necessary and a finding by the President that continued production is in the national interest. This report assesses the need to continue production of the NPRs, including analyzing the benefits and costs of extending production or returning to the shut-in status that existed prior to 1976. This continued production study considers strategic, economic, and energy issues at the local, regional, and national levels.
\end{abstract}


TABLE OF CONTENTS

Page

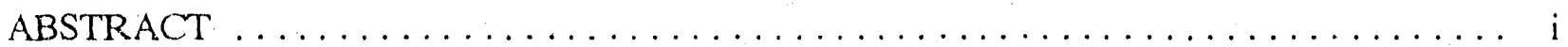

ABBREVIATIONS $\ldots \ldots \ldots \ldots \ldots \ldots \ldots \ldots \ldots \ldots \ldots \ldots \ldots \ldots \ldots \ldots$ iii

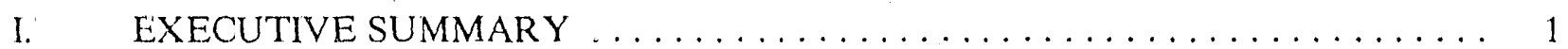

II. $\quad$ BACKGROUND ...................................... 6

A. HISTORY OF THE NAVAL PETROLFUM RESERVES $\ldots \ldots \ldots \ldots \ldots \ldots 6$

B. NAVAL PETROLEUM RESERVE NUMBERED $1 \ldots \ldots \ldots \ldots \ldots \ldots, 1.3$

C. NAVAL PETROLEUM RESERVE NUMBERED $3 \ldots \ldots \ldots \ldots \ldots \ldots 21$

III. ANALYSIS OF CONTINUED PRODUCTION $\ldots \ldots \ldots \ldots \ldots \ldots \ldots \ldots \ldots . \ldots \ldots$

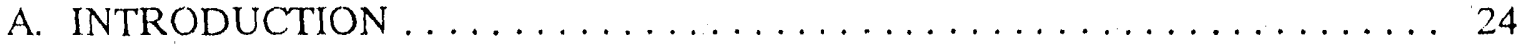

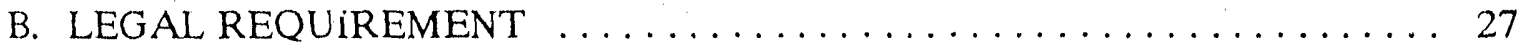

C. CONTINUEIS PRODUCTION UNDER CURRENT LAW $\ldots \ldots \ldots \ldots \ldots, 28$

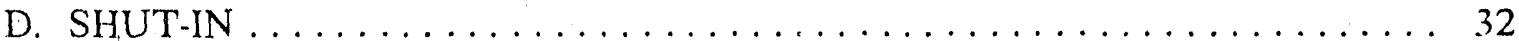

E. PETROLEUM PRICE ASSUMPTIONS . .................. 36

F. COMPARISON OF SHUT-IN AND INTERMEDIATE PZODUCTION

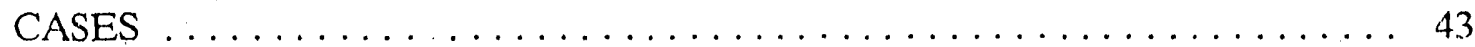

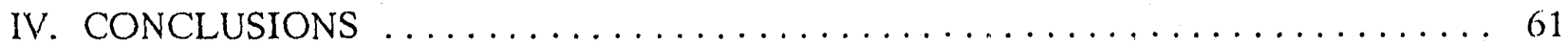

APPENDIX I LIST OF RESPONDENTS TO DOE REQUEST FOR COMMENTS $\ldots \ldots \ldots \ldots \ldots \ldots \ldots \ldots \ldots \ldots \ldots \ldots$ PAGE I- 1

APPENDIX II BASELINE 'RODUCTION CASES $\ldots . \ldots \ldots \ldots \ldots \ldots \ldots$ PAGE II-1

APPENDIX III MANAGEMENT UF SHUT-IN RESERVOIRS $\ldots \ldots \ldots, \ldots$ PAGE III-1 APPENDIX IV SENSITIVITY CASES $\ldots \ldots \ldots \ldots \ldots \ldots \ldots \ldots \ldots \ldots$ PAGE IV-1 


\section{ABBREVIATIONS}

-A-

AEO90 Annual Energy Outlook 1990
ANS
$\begin{gathered}\text { Alaskan North Slope (crude oil) } \\ -B-\end{gathered}$

BBLS Barrels

BCF Billion Cubic Feet

BOE Barrels of Oil Equivalent

BOPD Barrels of Oil Per Day

-D-

DCF Discounted Cash Flow

DOD Department of Defense

DOE Department of Energy

$-E$ -

EIA Energy Information Administration

EO Executive Order

EOR Enhanced Oil Recovery

$-G$ -

GAL/D Gallons Per Day

GRH Gramm-Rudman-Hollings Act

$-M-$

MB Thousarid Barrels

MMB Million Barrels

MMB'TU Million BTU

MCF Thousand Cubic Feet

MCF/D Thousand Cubic Feet Per Day

MER Maximum Efficient Rate of Production

MGAL Thousand Gallons

MMCF Million Cubic Feet

MMCF/D Million Cubic Feet Per Day

Mi.MAL Million Gallons 


\section{Abbreviations (continued)}

$-\mathrm{N}-$

NES National Energy Strategy

NGL Natural Gas Liquid

NPR-1 Naval Petroleum Reserve Numbered 1 (Elk Hills, California)

NPR-2 Naval Petroleum Reserve Numbered 2 (Buena Vista, California)

NPR-3 Naval Petroleum Reserve Numbered 3 (Teapot Dome, Wyoming)

NPV Net Present Value

.0 -

OCS Outer Continental Shelf

OMB Office of Management and Budget

OPEC Organization of Petroleum Exporting Counties

$-S-$

SJV San Joaquin Valley

SOCAL Standard Oil Company of California (now Chevron)

SPR Strategic Petroleum Reserve

$-U$ -

USC United States Code

USG United States Government 


\section{EXECUTIVE SUMMARY}

\section{INTRODUC'TION}

The Naval Petroleum Reserves (NPRs) swere established by a series of Executive Orders between 1912 and 1915 that Congress later ratified by passing several laws. This report presents a study of whether production should be continued at two NPRs now administered by the Department of Energy: Naval Petroleum Reserve Numbered 1 (NPR-1, also known as Elk Hills), a large oil field located in Kern County, California; and Naval Petroleum Reserve Numbered 3.(NPR-3, also known as Teapot Dome), a small oil fiekd located near Casper, Wyoming.

After World War II, the NPRs were produced at low levels or were effectively shut in until the Naval Petroleum Reserve Production Act of 1976 authorized the production of the Reserves at their maximum efficient rates (MER) for an initial 6-year period ending in April 1982. In addition, the Act provided Presidential authority to continue production after the initial six years, in increments of up to three years each. Production extensions are based upon an investigation, conducted by the President, which determines the necessity for continued production. The findings of the investigation are presented in a report to Congress in conjunction with a Presidential certification that continued production is in the national interest.

Since 1976, Naval Petroleum Reserves Numbered 1 and 3 have been under production at their MERs, as required by the Naval Petroleum Reserve Production Act of 1976. Production is currently authorized through April 5, 1991.

This repurt summarizes the findings of a study comparing the economic effect of continued production to the effects of shutting in the Reserves and recommends continued production of the NPRs at MER from April 5, 1991, through April 5, 1994. The report takes into consideration the themes set forth in the Interim Report of the National Energy Strategy, particularly the theme titled "Secure Future Energy Supplies". 
The chcice between continued production and shutting in the Reserves is evaluated in terms of four criteria:

- National Economic Impacts - including both the direct effect of the decision on net Federal revenues from NPR production and effects on the econo:ny.

- National Energy Strategy - reflecting the effects of an NPR shut-ir. on U.S. oil import requirements and domestic oil production.

- Local and Regional Concerns - involving the effects of continued production of the NPRs on local economies and on the petroleum industry in the areas served by the NPRs.

- Military Preparedness - reflecting the original purpose of the NPRs.

The report concludes that continued production of the NPRs has clear advantages over shutin in terms of all of these criteria.

\section{NATIONAL ECONOMIC IMPACTS}

Net present value analysis shows that revenues received in the 1990 s are worth significantly more than revenues that would be received after the year 2000 if the NPRs were shut in cluring the $1990 \mathrm{~s}$.

The following table shows the net present value of an intermediate continued production case compared to shutting in NPR-1. The intermediate production case has a higher net present value: for each of the four price cases studied (an Office of Management and Budget case and three Annual Energy Outlook price cases, each adjusted to reflect California oi market price differentials) than the shut-in case. 


\section{ELK HILLS ECONOMIC VALUE, 1991-2020}

(NPV in Millions of 1990 Dollars)

\begin{tabular}{|c|c|c|}
\hline Price Case & Intermediate Production & Shut-In \\
\hline OMB & $\$ 2,023$ & $\$ 1,257$ \\
\hline AEO-Low & 2,495 & 2,039 \\
\hline AEO-Base & 3,572 & 2,929 \\
\hline AEO-High & 4,373 & 3,599 \\
\hline
\end{tabular}

Shutting in NPR-3 would deprive both the Rocky Mountain area of a small but needed amount of oil and the Federal Government of small but useful revenues. It is likely that NPR-3 could not he shut in and restarted again economically, so the Government's best interest is served by continuing to operate the field as long as it is profitable.

\section{NATIONAL ENERGY STRA'TEGY}

If NPR production were shut in, oil that is not produced would have to be replaced by increased imports. In addition, any natural gas or natural gas liquids that had previously been sold for public consumption would also have to be replaced somehow. If NPR-1 were shut in during the 1990s, approximately $40-80,000$ barrels of oil imports per day would be required to replace NPR-1 production.

Continuing production at MER for three years will enhance the availability of petroleum supplies and avoid any upward pressures on world oil prices due to an increase in U.S. oil imports. However, the small supply represented by NPR-1 will not be a substantial factor in influencing world oil prices, since NPR-1 production represents only about one percent of U.S. petroleum production capacity. 


\section{LOCAL AND REIIIONAL CONCERNS}

Shutting in NPR-1 would result in significant unemployment in Kern County, California. It would also likely result in an increase in the cost of refined products in California's San Joaquin Valley of several cents per gatton due to increased transportation costs. The supply of locally produced petroleum products would decline and their price would rise.

Several small independent refiners in the Bakersfield area depend on Elk Hills light crude oil for their refineries. Elk Hills is the largest block of crude oil production in California that is not controlled by a major oil company. It is virtually the only source of light crude oil run by these refineries, which are designed to convert light crude oil to gasoline, military and commercial jet fuel, diesel fuel, and fuel oil. Many of them would not be able to acquire suitable replacement crude oil if Elk Hills were shut in, and some would probably close. Shutting in NPR-1 would also have adverse effects on local pipelines and on local heavy oil producers who blend light Elk Hills oil with heavier crude oil so it can be shipped in pipelines.

Continued production will avoid adverse impacts on industry and employment in Casper, Wyoming. Shut-in would result in the loss of several hundred jobs in an economically depressed area. This could also have an impact on the responsiveness of the local oil industry to a future energy emergency, as some service firms could leave the area if NPR-3 were shut in.

\section{MILITARY PREPAREDNESS}

NPR production is useful in meeting defense or other needs in the event of an energy emergency. In the event of shut-in, however, production could not be started quickly enough to mitigate the emergency.

A short-term crude oil supply shortage can be more effectively met by the drawdown of the Strategic Petroleum Reserve (SPR). When completed to the Administration's target level, the SPR will contain 750 million barrels of crude oil. The current SPR crude oil inventory is nearly 60() 
million barrels. Based on recent estimates, the SPR is capable of drawing down and distributing its inventory at the initial rate of 3.5 million BOPD, and plans call for further increases in the SPR drawdown rate to 4.5 million $B O P D$. This rate is more than 36 times the current crude oil production rate at NPR-1. NPR-1 would not be an effective or efficient means of providing oil storage for use in an oil supply disruption because of the relatively low rate at which oil could be produced from the Reserve and the length of time required to start production after the field has been shut in.

In addition, the Secretary of Energy has authority under the SPR Distribution Plan to direct up to 10 percent of an SPR drawdown to various users. Although there are no current plans to do so, the Secretary could use this authority to direct up to 10 percent of an SPR drawdown to the Department of Defense or its suppliers.

The potential production rates at NPR-3 are so small that there would be virtually no defense value or other national benefit in conserving NPR-3 for future use. NPR-3 production was only 2,281 BOPD in 1989.

\section{CONCLUSIONS}

This report concludes that it is in the national interest to continue production of Naval Petroleum Reserves Numbered 1 and 3 for another three years through April 5, 1994. This conclusion is based on a number of study findings resulting from the comparison of a shut-in scenario and several continued production scenarios. 'These findings are summarized above and presented in detail in this report.

It is worth noting that none of the wide range of cases considered in the study favored shutting in the Reserves under any evaluation criteria: national economic impacts; national energy strategy; local and regional impacts; and military preparedness. In addition, all of the public comments received from parties iriterested in the study strongly supported continuing production. 


\section{BACKGROUND}

This chapter provides a legislative and operational history of the Naval Petroleum Reserves and describes their purpose in meeting national energy needs. Each of the Reserves is described in detail as to size, production rates, sales revenues, and regional market position.

\section{A. HISTORY OF THE NAVAL PETROLEUM RESERVES}

The Naval Petroleum Reserves (NPRs) were established by a series of Executive Orders between 1912 and 1915 to provide emergency fuel for the Navy's fleet as it converted from coal to oil. Congress subsequently ratified the establishment of the Reserves through the enactment of various laws now codified in title 10, United States Code, Chapter 641. The petroleum reserves analyzed in this study are NPR-1 (Elk Hills) in Kern County, California, and NPR 3 (Teapot Dome) near Casper, Wyoming.

The Government also owns Naval Petroleum Reserve Numbered 2 (Buena Vista Hills), which borders NPR-1 to the south. NPR-2 is not analyzed in this continued production study because the Government's productive acreage in NPR-2 has been leased since the 1920s, and production will continue under the terms of those leases as long as they are commercially viable.

\section{2-1942}

President William Howard Taft created NPR-1 (Elk Hills) by Executive Order on September 2, 1912. As originally constituted, NPR-1 consisted of approximately 38,000 acres of oil-bearing land reserved for the "exclusive use or benefit of the United States Navy."1 Originally, about 12,000 acres of NPR-1 were privately owned, primarily by Southern Pacific Railroad and Standard Oil Company of California (SOCAL), which later became successor in interest to Southern Pacific, while the

1 Exccutive order dated September 2, 1912. 
FIGURE II-1

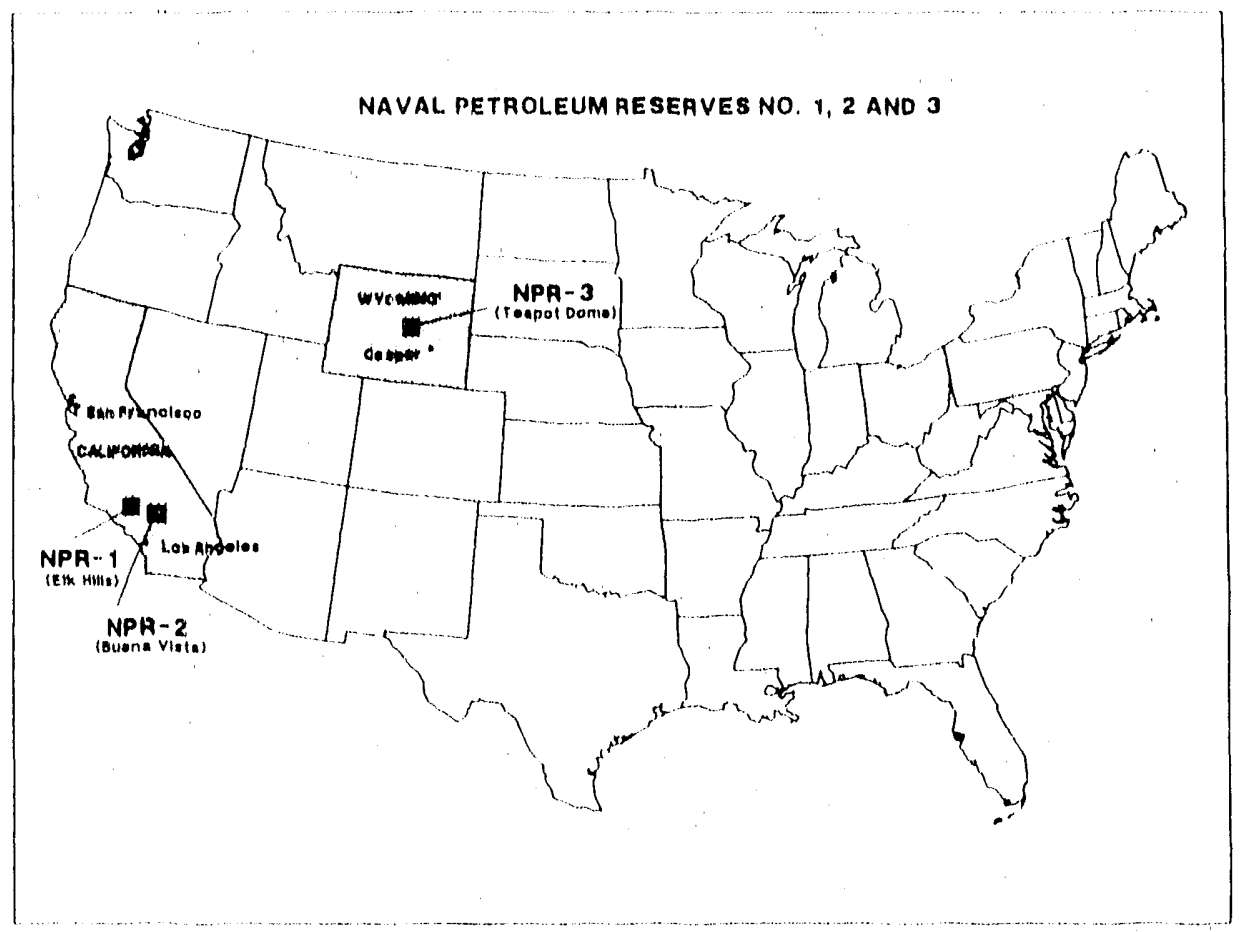

remaining 26,000 acres belonged to the U.S. Government. Southan Pacilic lost $91 / 2$ of its $163 / 4$ sections ${ }^{2}$ in litigation with the U.S. over the validity of its railroad grants.

NPR-2 (Buena Vista Hills, California) was created by Executive Order, dated December 13, 1912. It covers 30,181 acres and is adjacent to the south perimeter of NPR-1. The Government owns 10,446 acres within the boundaries of NPR-2 or 34.6 percent of its area, and the remainder is privately held. Because the Government acreage "checkerboards" NPR-2, all of the Government's productive acreage has been leased and produced continuously since the $1920 \mathrm{~s}$.

NPR-3 (Teapot Dome) was established in a similar fashicn by Executive Order on April 30, 1915, by President Woodrow Wilson. Located approximately 35 miles north of Casper, Wyoming, the Reserve covers about 9,500 acres and is wholly owned by the U.S. Government.

2 Per governmental survey, a section of land is about 1 square mile or 640 acres. 
SOCAL drilled the first producing well on its NPR-1 acreage in 1919. By 1921, 60,000 barrels of oil per day (BOPD) were being produced from NPR-1-none of it on government land. Although the Reserves had been set aside for the benefit of the Navy, the Navy had no jurisdiction over the Reserves until 1920. On June 4, 1920, the Naval Appropriations Act (41 Stat. 813) placed the NPRs under the authority of the Secretary of the Navy and authorized the Secretary to conserve, develop, use, and operate the Reserves at his discretion for the benefit of the United States Navy.

After the Navy's jurisdiction over the NPRs had been established in 1920, the Office of Naval Operations developed a plan of conservation that provided for the drilling of offset wells, through leasing, to protect against drainage. The Department of the Interior proposed that the Navy take its royalty from the leasing in the form of fuel oil in storage tanks at seaports as a defense reserve stock. However, it was concluded within the Goverument that the Navy did not have the authority to eriter into such lease arrangements. To create an opportunity for NPR leasing, President Harding transferred administration of the NPRs to the Secretary of the Interior, who was Albert 5 . Fall at that time, by Eyecutive Order No. 3473 on May 31, 1921. However, this action was never submitted to the Congress for confirmation. Portions of NPR-1, NPR-2, and NPR-3 were subsequently leased to private oil companies that drilled wells and produced oil and gas from the fields. Most of the NPR-1 a 1 d NPR-3 leases were canceled and production halted in 1927 after a lengthy Congressional investigatic $n$ found that there was no authority to produce oil for exchange purposes. ${ }^{3}$

Later, in 1927, the Supreme Court also found that there was no authority to produce the oil for fuel oil exchange purposes. The Court indicated that Congressional intent was clear that NPR oil was to remain in the ground as a defense reserve, with production used only as a means to protect the oil assets from drainage or losses.

On March 17, 1927, after about 85 million barrels of oi! had been produced, President Calvin Coolidge returned NPR jurisdiction to the Navy by Executive Order No. 4614. Navy control of NPR-

3 The Secretary of the Interior let a number of leases on the reserves for fuel oil and tank storage. It was determined that the leases were illegal and that some had been obtained fraudulently. These actions have been known historically as the Teapot Dome scandal. 
1 leases was re-established by the Act of February 25, 1928 (45 Stat. 148). All NPR-1 leases were later either terminated or expired by their own terms.

Between 1927 and 1942, the Reserves were not developed except for some offset protective drilling. Available records indicate that the Navy and SOCAL had an understanding not to engage in drilling inside NPR-1 without giving six months notice to one another. ${ }^{4}$ The Act of June 30,1938 (52 Stat. 1252), granted the Navy new authority to deal with drainage by contracting with private owners for conservation of oil in the ground and by exchanging Government lands and royalty oil for privately owned lands within NPR-1. On October 15, 1942, President Franklin D. Roosevelt expanded NPR-1 by means of Executive Order No. 9257, and NPR-1 was enlarged to the east by 5,842 acres to include the balance of the known geologic structure of the Shallow Oil Zone.

\section{$1942-1973$}

In late 1940, SOCAL provided the Navy with six months notice that it intended to drill on its lands within NPR-1. The Navy reacied by seeking funds for test drilling, but President Roosevelt vicwed this as too time consuming and authorized the Secretary of the Navy to enter into negotiations for the purchase of all private NPR-1 lands in the same geologic structure and, if satisfactory arrangements could not be promptly concluded with SOCAL, to commence condemnation proceedings through the Department of Justice. SOCAL (now Chevron U.S.A. Inc.) and the Navy reached an agreement nn a Unit Plan Contract on November 20, 1942, which resulted in a combined operating strategy for NPR-1. The thrust of the agreement was cooperative exploration, development, and operation of lands within NPR-1. This initial contract was later rescinded by mutual agreement, and the current Unit Plan Contract was executed on June 19, 1944, following the enactme.'t of Public Law 343 (58 Stat. 280, June 17, 1944), which provided the requisite authority for the contract.

4 "History of Naval Petroleum Reserves," S. Doc. No. 187, 78th Congress, 2nd Session, 24 (1944). 
The Unit Plan Contract provides that NPR-1 is to be operated as a single property and granted the Navy, subject to the provisions of the contract, absolute control over (1) the time and rate of exploration and development and (2) the quantity and rate of production. The contract also states that production at NPR-1 must be authorized by the Congress. Rather than operate the Reserves with its own personnel, the Navy chose to work through a contractor. Standard Oil was awarded the operator's contract through a competitive bidding process in 1944 and continued to operate NPR-1 for the next 31 years.

Shortly after the Unit Plan Contract was signed, Congress authorized producing NPR-1 at a level of 65,(000 BOPD to address fuel shortages on the West Coast and World War II military needs. Following the end of the war, production was cut back to 8,500 BOPD in May 1946. NPR-1 production was increased to 21,000 BOPD in 1953 to minimize damage to the field and to avoid permanent loss of oil. Production was later decreased and was roughly 3,000 BOPD for the three years before NPR-1 was reopened for full production in 1976.

During this period, NPR-2 continued to be produced on the 17 leases, with the Government receiving its royalty share as it does today. NPR-3 saw a period of production during World War II and a stint of offset production in the 1950's to counteract drainage. Except for these periods of production, NPR-3 was in shut-in status.

\section{4-1976}

Following the Arab oil embargo of 1973-1974, the Congress passed Public Law 93-245 (the Supplemental Appropriation Act of 1974) to authorize NPR development to address emergency cnergy needs. The law authorized developing NPR-1 and NPR-3 to their full economic potential, but full production was not authorized at this time. After lengthy debate, full production was authorized by the Naval Petroleum Reserves Production Act of 1976 (Public Law 94-258). The Act required that NPR-1, NPR-2, and NPR-3 be produced at their maximum efficient rates for six years. The law also provided the President discretionary authority to extend production for an unlimited number of terms in increments of up to three years each, if the President submits to Congress, 180 
days prior to the end of the current production period, a report on the necescily of continuing production and a certification by the President that continued production is in the national interest.

\section{6-Present}

The Navy began full production at NPR-1 and NFR-3 on July 3, 1976. Cumulative production prior to this "open-up" date totaled approximately 300 million barrels of oil; total revenues derived from carlier NPR-1 production were approximately $\$ 265.5$ million. 'The Secretary of the Navy continued to administer NPR-1 and NPR-3 until the Department of Energy Organization Act (Public Law 9.5-91) transferred ju:isdiction of the NPRs to the new Department of Energy (DOE), effective October 1, 1977.

All oil and gas production designated for sale was made available to the private sector by DOE as provided for in the 1976 NPR Production Act. Contracts were offered on the open market using competitive bidding procedures from open-up through FY 1980. At that time, Congress passed legislation authorizing the transfer of NPR. prociuction to the Department of Defense, if needed for defense purposes, and amended authority to transfer oil from the NPRs to the Strategic Petroleum Reserve (SPR). Commencing in F'Y 1981, the Government's share of NPR oil was either (1) transferred to the SPR or exchanged competitively for oil delivered to the SPR, (2) transfcrred to the Department of Defense (DOD), or (3) sold on the open market when not all of the oil was taken by the SPR or DOD. Since November 1986, however, all of the Government's share of production has been sold competitively on the open market except for a small amount transferred via pipeline in 1987 from NPR-1 to SPR to test the viability of such a transfer.

In accordance with the 1976 NPR Production Act, President Reagan determined that continued production of the NPRs was in the national interest in 1981, 1984, and again in 1987. Accordingly, NPR-1 and NPR-3 have been producing at maximum efficient rates since July 3, 1976, and are currently authorized to produce through April 5, 1991. Because NPR-2 has been leased oul and under continuous production since the 1920s, the bulk of NPR-2's recoverable reserves has becu produced. Over 645 MMB of oil had been produced from NPR-2 by the end of FY 1989, or an 
estimated 98-99 percent of NPR-2's ultimate recoverable reserves. Estimated remaining recoverable reserves are only about 7 MMB. During FY 1989, production from NPR-2 averaged 1,372 BOPD, with the Government's royalty share being 173 BOPD. The Naval Petroleum Reserves Production Act of 1976 had no effect on the NPR-2 leases and, for this reason, no decision on the continued production of NPR-2 is required.

Since enactment of the Naval Petroleum Reserves Production Act of 1976, the Government has received $\$ 14.1$ billion in revenues from the NPRs and incurred $\$ 2.4$ billion in operating costs, for $\$ 11.7$ billion in net revenues.

TABLE IR-1

NPR HISTORICAL MILESTONES

$\begin{array}{lll}\text { Authority } & \text { Date } & \text { Description } \\ \text { E.O. } & \text { Jun } 1909 & \text { Temporary withdrawal of lands } \\ \text { E.O. } & \text { Jul } 1910 & \text { Confirmed temp. withdrawal of lands } \\ \text { E.O. } & \text { Sep } 1912 & \text { Establishment of NPR-1 } \\ \text { E.O. } & \text { Apr } 1915 & \text { Establishment of NPR-3 } \\ \text { 41 Stat. } 813 & \text { Jun } 1920 & \text { NPRs under authority of Dept. of Navy } \\ \text { E.O. 3473 } & \text { May } 1921 & \text { Transfer to Dept. of Interior } \\ \text { 41 Stat. } 148 & \text { Feb } 1928 & \text { Return authority to Navy } \\ \text { 58 Stat. } 280 & \text { Jun } 1944 & \text { Authorize SOCAL Unit Plan Contract } \\ \text { P.L. 94-258 } & \text { Apr } 1976 & \text { NPR Production Act } \\ \text { P.L. 95-258 } & \text { Oct } 1977 & \text { Transfer authority to DOE }\end{array}$




\section{NAVAL PETROLEUM RESERVE NUMBERED 1}

NPR-1, Elk Hills, is located approximately 35 miles southwest of Bakerslield, California. T'oday, the Reserve covers almost 48,000) acres and ranks as the seventh largest producing oil field in the contiguous United States. It also contains natural gas reserves exceeding onc-and-a-hall trillion cubic feet, making it the largest gas field in California. ${ }^{5}$

FIGURE 1I-2

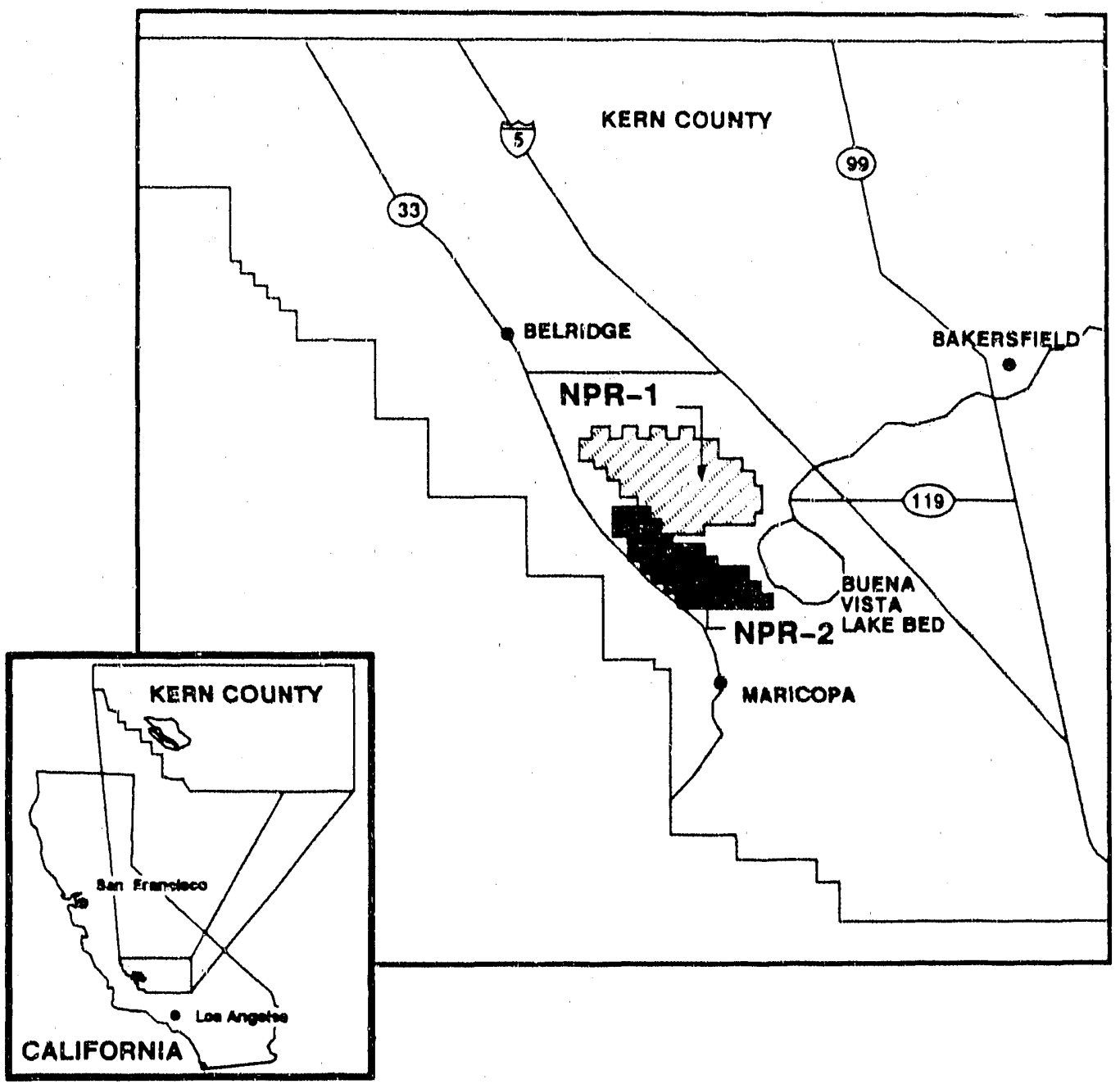

5 Naval Petroleum Reserves in California Long Range Plan, FY 1989-1995, p. i. 
Under the Unit Plan Contract with Chevron ${ }^{6}$, NPR-1 is operated on a reservoir-by-reservoir basis, rather than on a parcel-by-parcel basis, to allow for more efficient and greater recovery of petroleum resources. The 14 reservoir groups that have been identified at Elk Hills are produced from four different stratigraphic zones: the Dry Gas Zone, the Shallow Oil Zone, the Carneros Zone, and the Stevens Zone, which is the most productive of the four (see Figure 11-3). 'Three of these zones, the Dry Gas Zone, the Shallow Oil Zone, and the Carneros Zone, are considered contiguous geologic formations that cover large areal portions of the field (see Figure II-4). The Stevens Zone, by contrast, produces from more distinct reservoirs, with varying degrees of communication between them ${ }^{7}$. A small quantity of irude oil is also produced from the Asphalto Field in the northwest portion of the Reserve; however, producticin is very small compared to the four primary zones. Each owner's participating percentage of produstion from these producing zones at Elk Hills is shown in Table II-2.

TABLE II-2

PAR'TICIPATING PERCENTAGES OF NPR-1 PRODUCTIION ${ }^{8}$

\begin{tabular}{lcc}
\hline Zone & Government & Chevron U.S.A. \\
Dry Gas & $77.0492 \%$ & $22.9508 \%$ \\
Shallow Oil & 70.0119 & 29.9881 \\
Stevens & 79.6357 & 20.3643 \\
Carneros & 100.0000 & 0.0000 \\
\hline
\end{tabular}

6 SOCAL changed its name to Chevron USA on January 1, 1977.

7 Naval Petroleum Reserves in California Long Range Plan, FY 1989-1995, pp. ii, iii.

8 Naval Petroleum and Oil Shale Reserves Annual Report of Operations, FY 1989, p. 6. 
FIGURE II-3

\section{NPR-1 \\ GENERALIZED GEOLOGIC CROSS SECTION}

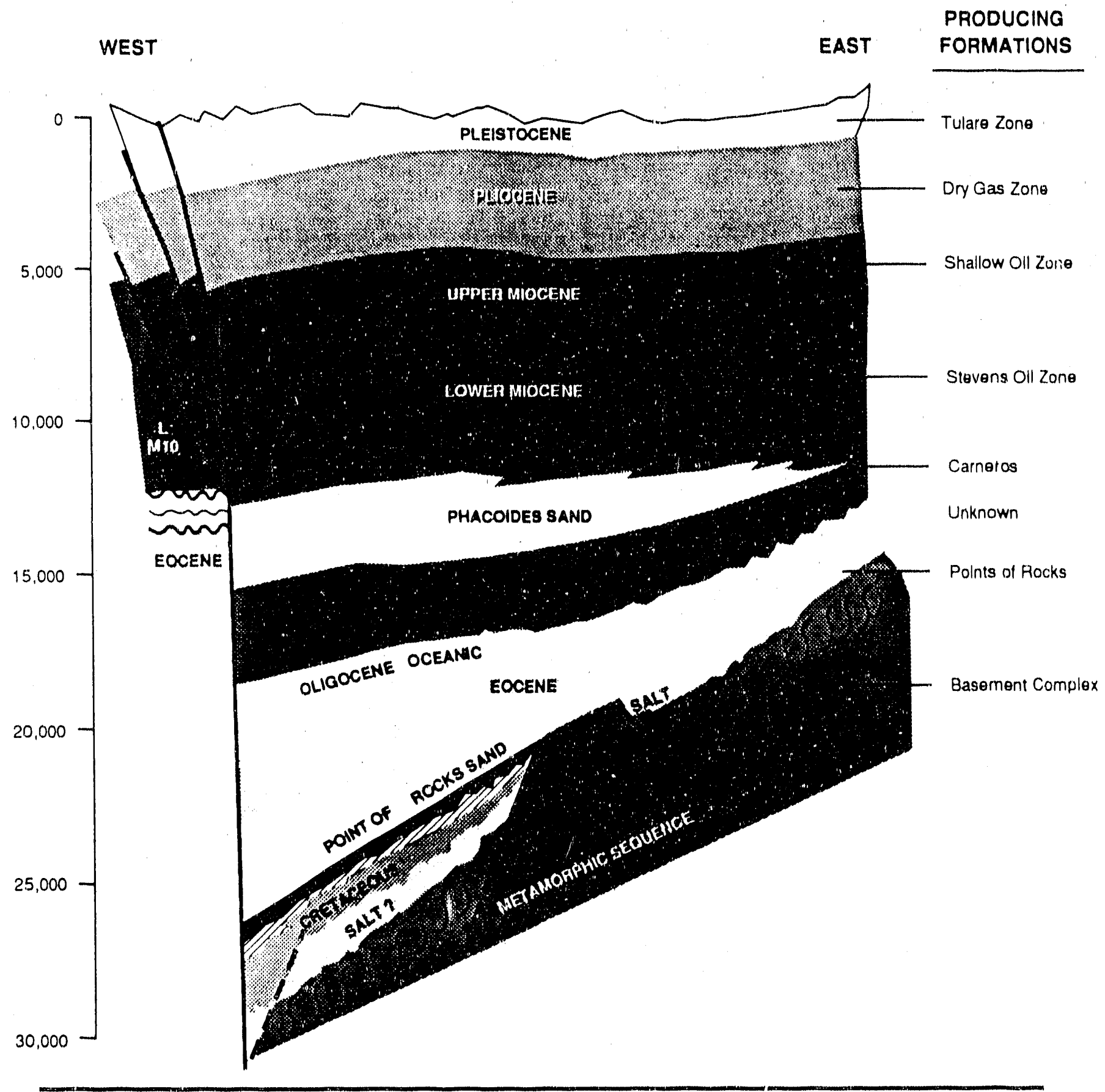




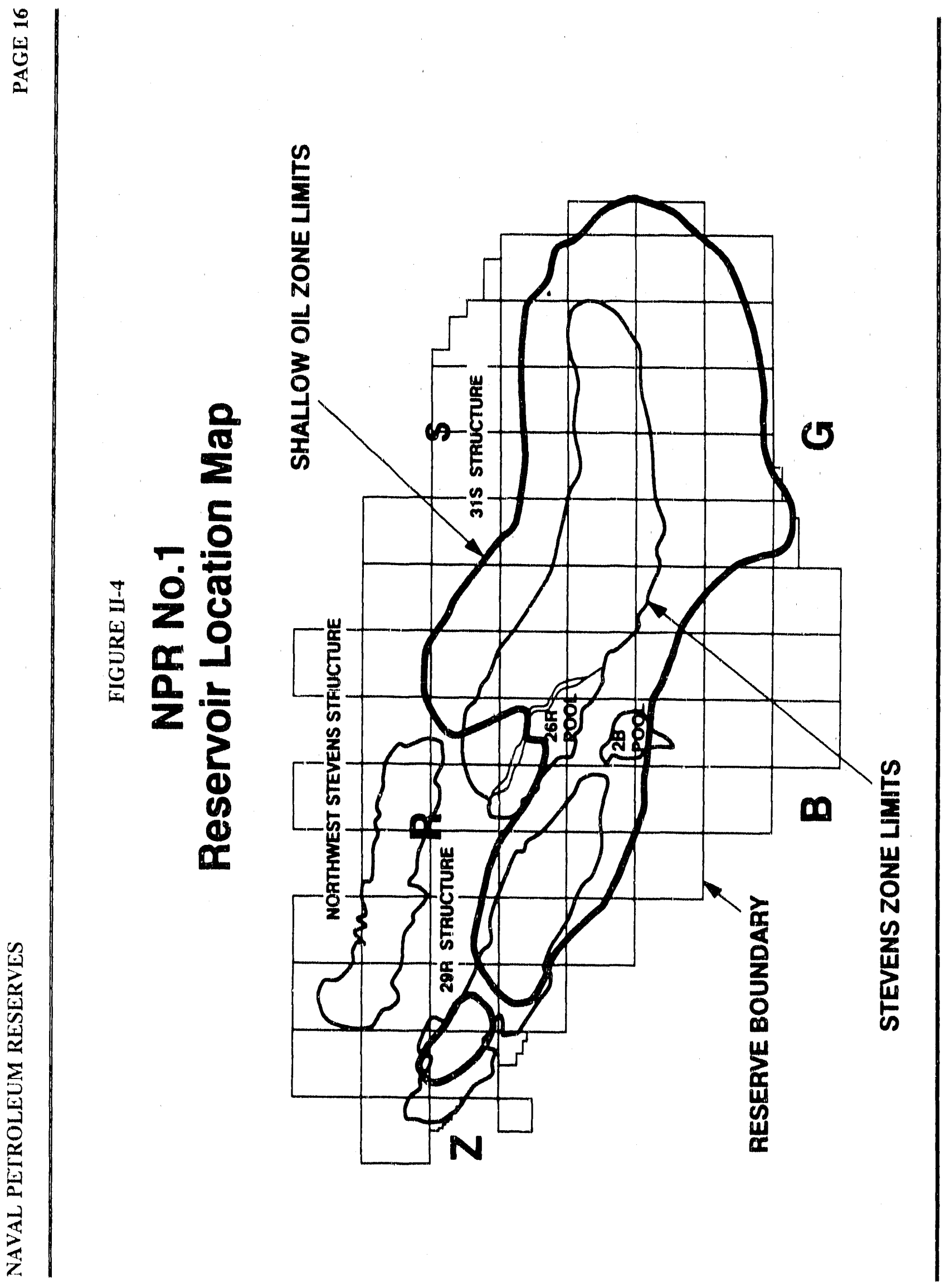




\section{NPR-1 CRUDE OIL}

\section{Production}

Since the establishment of NPR-1 in 1912, over 931 million barrels of crude oil have been produced at Elk Hills through FY 1989. Roughly 300 million barrels of that total were produced before open-up on July 3, 1976. NPR-1 reached its peak rate of production (181,000 BOPD) in July 1981. The field is now considered mature and the rate of production has declined consistently since the peak rate occurred. NPR-1 total oil production since 1976 is displayed in Table II-3.

In FY 1989, daily production averaged 96,479 BOPD, of which the Government's share was 75,403 BOPD. Most of the production, $8(0,390$ BOPD, was produced from the Stevens Zone and had an average gravity of approximately $36^{\circ} \mathrm{API}$. Production from the Snallow Oil Zone averaged 15,690 BOPD with an average gravity of approximately $25^{\circ}$ API.

\section{$\underline{\text { Sales }}$}

All of the Government's FY 1989 share of NPR-1 crude oil production was sold competitively on the open market to commercial firms in two 6-month offerings. The first, beginning on October 1, 1988, awarded 79,180 BOPD to 12 companies. Actual deliveries under these contracts averaged 76,807 BOPD at an average price of $\$ 14.09$ per barrel. The second set of contract awards was for the period April 1, 1989 to October 1, 1989. Awards of 75,600 BOPD and actual deliveries of 74,125 BOPD were made to 7 companies. The average price of the second set of contracts was $\$ 18.45$ per barrel. Small refiners successfully bid for 25 percent of the oil sold in the first period and 40. percent of the oil sold in the second period. 
TABLE II-3

NPR-1 TOTAL CRUDE OIL PRODUCTION"

\begin{tabular}{cccc}
$\begin{array}{c}\text { Fiscal } \\
\text { Year }\end{array}$ & $\begin{array}{c}\text { Annual } \\
\text { (MMB) }\end{array}$ & $\begin{array}{c}\text { Daily } \\
\text { SMB/D) }\end{array}$ & $\begin{array}{r}\text { Cumulative } \\
\text { (MMB) }\end{array}$ \\
1976 & 3.8 & 10.4 & 3.8 \\
1977 & 37.0 & 101.4 & 40.8 \\
1978 & 43.5 & 119.2 & 84.3 \\
1979 & 52.6 & 144.1 & 136.9 \\
1980 & 58.3 & 159.7 & 195.2 \\
1981 & 62.6 & 171.5 & 257.2 \\
1982 & 60.7 & 166.3 & 318.5 \\
1983 & 57.3 & 157.0 & 375.8 \\
1984 & 50.5 & 138.4 & 426.3 \\
1985 & 47.7 & 130.7 & 474.0 \\
1986 & 42.2 & 115.6 & 516.2 \\
1987 & 39.8 & 109.0 & 556.0 \\
1988 & 39.3 & 107.7 & 59.5 .3 \\
1989 & 35.2 & 96.4 & 630.5 \\
& & & \\
\hline
\end{tabular}

9 Report to the Congress on Alternative Financing Methods for the Strategic Petroleum Reserve, February 1, 1990, DOE/FE-(0155, p. VIII-5. 


\section{NPR-1 NA'TURAL GAS}

\section{$\underline{\text { Production }}$}

With natural gas reserves exceeding one-and-a-half trillion cubic feet, NPR-1 is also one of the nation's top ten producing gas fields. In FY .1989, the Reserve maintained a production rate of $369 \mathrm{MMCF} / \mathrm{D}$.

\section{Sales}

During FY 1989, natural gas was sold in three offerings for periods of four months each. Approximately 30 percent of the Government's share of natural gas produced at NPR.1 was sold; the remainder was either reinjected in NPR-1 to maintain reservoir pressures or used in field operations. The sales data for each of the three offerings can be found in Table II-4. ${ }^{10}$

TABLE II-4

RECENT NPR-1 NATURAL GAS SALES DATA

\begin{tabular}{||l|r|r|r|r|r||}
\cline { 2 - 5 } \multicolumn{1}{c|}{} & \multicolumn{3}{c||}{ OFFERINGS } \\
\cline { 2 - 6 } \multicolumn{1}{c|}{} & $\begin{array}{c}\text { Sept. 1, 1988- } \\
\text { Dec. 31, 1988 }\end{array}$ & $\begin{array}{c}\text { Jan 1, 1989. } \\
\text { Apr. 30, 1989 }\end{array}$ & $\begin{array}{r}\text { May 1, 1989- } \\
\text { Aug. 31, 1989 }\end{array}$ \\
\hline Contract Award (MMBTU/D) & 90,500 & & 104,500 & 104,000 \\
\hline Actual Deliveries (MMBTU/D) & 94,690 & & 91,946 & 96,673 \\
\hline $\begin{array}{l}\text { Average Sales Price } \\
\text { (\$MMBTU) }\end{array}$ & $\$ 2.51$ & & $\$ 2.48$ & $\$ 2.47$ \\
\hline $\begin{array}{l}\text { Number of Companies } \\
\text { Receiving Awards }\end{array}$ & 3 & & 4 & 2 \\
\hline
\end{tabular}

${ }^{10}$ Naval Petroleum and Oil Shale Reserves Annual Report of Operations, FY 1989, pp. 15-16. 


\section{NPR-1 NATLRAL GAS LIQUIDS}

\section{Production and Sales}

Natural gas liquids (propane, butane, and natural gasoline) are obtained as by-products from processing wet natural gas. In FY 1989, Elk Hills' production of these products totalled 184.9 million gallons: 69.3 million gallons of propane, 54.9 million gallons of butane, and 60.6 million gallons of natural gasoline. 11

In FY 1989, there was one 1-year sales offering of natural gas liquids from NPR-1. Contracts were awarded to 16 companies. Total contract awards for the Government share of natural gas liquids were $197,500 \mathrm{gal} / \mathrm{d}$ of propane, $146,000 \mathrm{gal} / \mathrm{d}$ of butane, and 177,000 gal/d of natural gasoline. The average sales price for each was $\$ 0.27$, $\$ 0.26$, and $\$ 0.35$ per gallon, respectively.

11 Naval Petroleum and Oil Shale Reserves Annual Report of Operations, FY 1989, p. 8. 


\section{NAVAL PETROLEUM RESERVE NUMBERED 3}

NPR-3, Teapot Dome, covers 9,481 acres located 35 miles north of Casper, Wyoming. The Reserve is a Federally owned oil field extending approximately seven miles along a north-south axis and two miles east to west. Activities at NPR-3 are managed by on-site Government personnel, while day-to-day operations are conducted by contractors, presently John Brown E \& C. In 1989, John Brown acquired Lawrence Allison \& Associates West, Incorporated, which had been the management and operating contractor for NPR-3 since October 21, 1981, and began a second 5-year contract on October 1, 1986.

\section{FIGURE II-5}

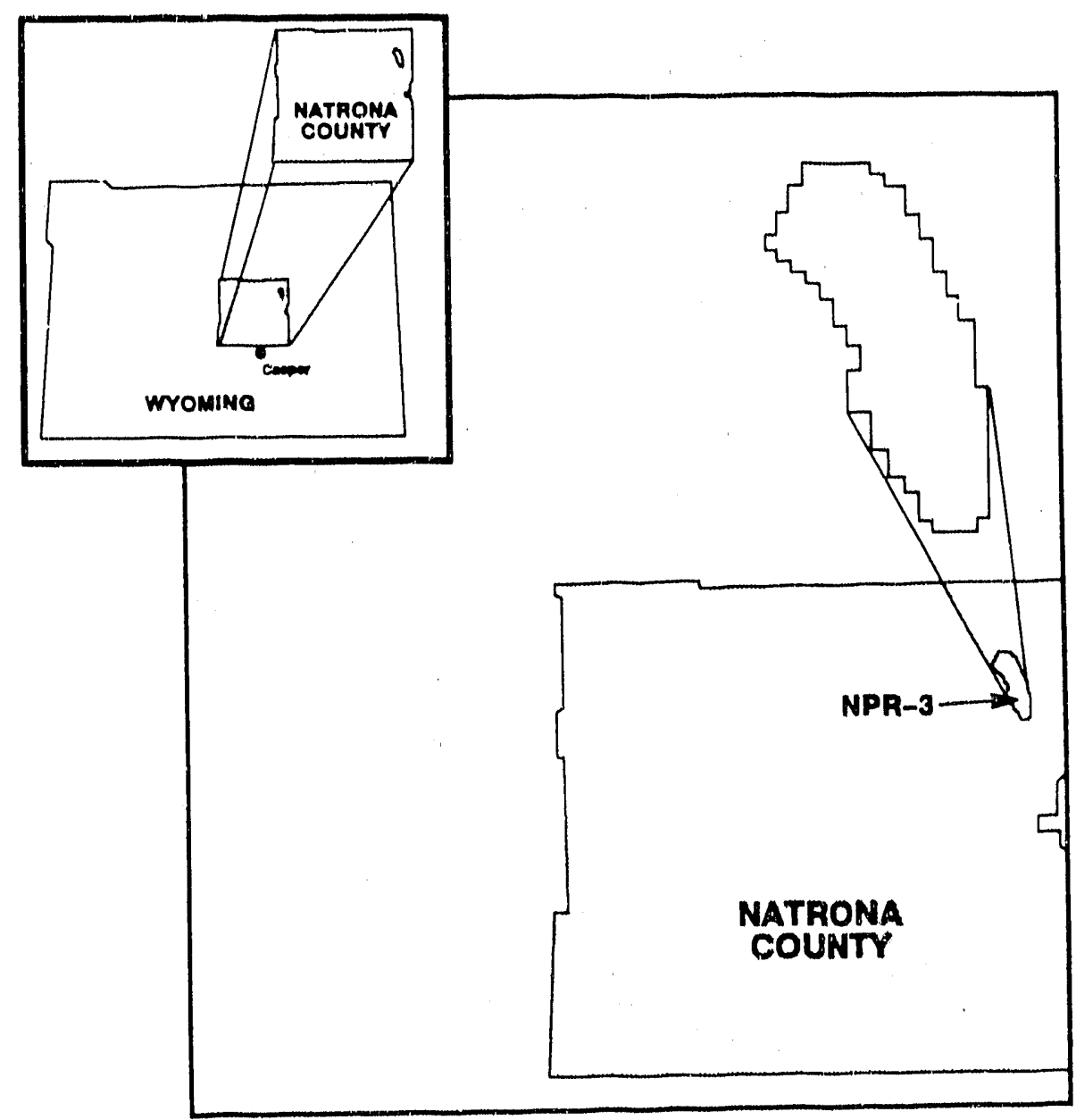


NPR-3 is a mature field of stripper wells, and production is managed to achieve maximum profitability as measured by discounted cash flow. Production of petroleum at NPR-3 includes crude oil, natural gas, and associated natural gas liquids (NGLs). Crude oil is sold on the open market, as are two NGL products, propane and a butane-gasoline mixture. Most of the natural gas produced at NPR-3 is reinjected for pressure maintenance, with the rest used in steam generation and minor field uses.

\section{NPR.3 PRODUCTION}

Cumulative production at NPR-3 before 1976 totaled 7.7 million barrels of crude oil with revenues of $\$ 20.5$ million. Since 1976, the mission of NPR-3 has been to produce petroleum at the maximum efficient rate, and an additional 14 million barrels have been produced. Exploration of the field has established the existence of ten oil and/or gas producing zones. The most important are the Shannon sand, the zones of fractured shales, and the Second Wall Creek sand.

Initial crude oil production at NPR-3 averaged 1,656 BOPD from July 3 to September 1976, and peaked at 4,393 BOPD in FY 1980. Thereafter, production steadily declined until FY 1986, when a successful drilling program increased production by 203 BOPD. A steam drive pilot project that began in 1985 offers the greatest possibility for increasing recoverable reserves through enhanced oil recovery. In FY 1989, over 800,000 barrels of crude oil were produced from NPR-3 at an average rate of $2,281 \mathrm{BOPD}$. 


\section{NPR-3 SALES}

Since February 1986, petroleum and petroleum products have been sold competitively on the open market by the Department of Energy. In FY 1989, revenues derived from all sources at NPR-3 totaled $\$ 16,096,309$.

In FY 1989, crude oil and natural gas liquids were sold from NPR-3 in four 3-month offerings. The crude oil was sold at an average price of $\$ 17.84$ per barrel. Associated natural gas liquids sales totaled 1,125,972 gallons of propane and 2,873,558 gallons of butane plus natural gasoline. The average prices per gallon were $\$ .19$ and $\$ .33$, respectively.

No natural gas has been sold since May 1, 1983. All natural gas produced is required for pressure maintenance through reinjection and for use in field operations. 


\section{ANALYSIS OF CONTINUED PRODUCTION}

\section{A. INTRODUCTION}

The Naval Petroleum Reserves have been under production since 1976 at maximum efficient rate (MER) which is required by the Naval Petroleum Reserves Production Act of 1976 for an initial 6-year period. The President was authorized under the 1976 Act to extend production in an unlimited number of increments of up to three years each after the initial term, if it were determined to be necessary and certified to Congress as being in the national interest.

This report summarizes the findings of a study evaluating the shut-in and continued production options available to the President and recommends continued production of the NPRs at MER from April 5, 1991, through April 5, 1994. The report takes into consideration the themes set forth in the Interim Report of the National Energy Strategy, particularly the theme titled "Secure Future Energy Supplies".

The principal approach of the analysis is to compare the economic effects of continued production to the effects of shutting in the Reserves. This requires development of forecasts for production (and associated costs) and petroleum prices, as discussed below.

This chapter evaluates the choice between continued production and shut-in in terms of four classes of effects:

- National Economic Impacts - including both the direct effect on net Federal revenues from NPR production and the broader effects on the economy due to the fact that shutting in Federal production would also reduce private sector production;

- National Energy Strategy - reflecting the effects of a shut-in on U.S. oil import requirements; 
- Local and Regional Concerns - involving the effects of the NPRs on local economies and on both upstream and downstream elements of the petroleum industry in the areas served by the NPRs;

- Military Preparedness - reflecting the original purpose of the NPRs.

The report concludes that continued production of the NPRs has clear advantages over shutin in terms of all of these criteria.

This chapter analyzes whether production should be continued or shut in at NPR-1 and NPR-3. As noted earlier, NPR-2, which is largely depleted, is produced under commercial leases; since no decision is required, NPR-2 is not analyzed in this study.

The quantitative analysis is focused on NPR-1, for several reasons:

- NPR-1 is one of the largest oil fields in the U.S. and the largest gas field in California;

- NPR-1 comprises the bulk of production from the NPRs, and it is much more accessible than NPR-3;

- It could be economical to restart NPR-1 if it were shut in, in contrast to NPR-3.

Continued production of NPR-3 through April 5, 1994, is in the national interest for the following reasons:

- Potential production at NPR-3 is so small that there would be no defense or other national benefits to conserving NPR-3 for future use; 1989 production was only 2,281 BOPD;

- NPR-3 could almost certainly not be restarted economically if it is shut in; therefore, it is in the Government's interest to operate the field as long as it continues to be profitable, as well as consistent with Government policy not to abandon marginal oil fields. 
- Shutting in NPR-3 would negate existing long-range enhanced oil recovery (EOR) efforts that could increase the ultimate total recovery from the Reserve; and

- Continued production of NPR-3 avoids adverse impacts on the people and industry of the Casper, Wyoming, area and avoids the loss of several hundred jobs in an economically depressed area. 


\section{B. LEGAL REQUIREMEN'T}

As discussed in Chapter 11, Naval Petroleum Reserves production was authorized and directeci by the Naval Petroleum Reserve Production Act of 1976 (Public Law 94-258). Pursuant to the Act, the Reserves were produced at their maximum efficient rates for an initial 6-year period ending in April 1982. In addition, the Act provided Presidential authority to extend production, subsequent to the initial six years of production, in increments of up to three years each. As required by the law, the production extensions are based upon a Presidential investigation that determines the necessity for continued production. The lindings of the investigation are presented in a report to Congress in conjunction with a Presiclential certification that continued production is in the national interest. President Reagan excrcised his authority to continue production on three occasions. As a result, production from the Reserves is currently authorized through April 5, 1991.

The purpose of this study is to fulfill the aforementioned legal requirements necessary for continued production of the Reserves. Two choices are available to the President under current law:

- Continue production at MER for up to three years beyond April 5, 1991; or

- Shut in production at a level that would protect the reservoirs from ultimately losing oil reserves, perhaps indefinitely or until a national defense emergency required the NPRs to be fully reactivated.

The methodology and evaluation criteria that will be used in this analysis are discussed in the following sections. 


\section{CONTINULI) PRODUC'TION UNDER CURRENT' LAW}

The approach used in this report is to compare a shut-in case with a range of continued production scenarios. This range of continued production scenarios is represented by three cases:

- Maintenance Case: A minimal approach to production that includes ne) new lacilities or drilling investments, no enhanced oil recovery projects, and no expenditures other than those required to continue operating the oil field with minimal effort.

- Intermediate Production Case: This intermediate continued production case reflects implementation of some, but not all, of the development projects in the Total Development Case.

- Total Development Case: A case that includes a number of development options such as steamflood, waterflood, development drilling, and additional natural gas injection.

The actual level of production and costs for Elk Hills will likely be between the Maintenance and Total Development Cises, since only the most promising investments are selected for implementation. The Department periodically reassesses the MER for each reservoir, taking into account current and planned capital improvements. The Intermediate Production Case is thus one of a number ol plausible cases, selected as a reasonable starting point for analysis of shut-in calses.

Projected NPR-1 oil production, natural gas sales, and NGL production are shown in Figures III-1, III-2 and III-3. These graphs illustrate a range of production possibilities associated with the Totill Development, Intermediate Production, and Maintenance Cases through 2()10. Natural gas sales rather than production are presented in Figure 1II-2. Much of the gas produced at NPR-1 is reinjected into the field to maintain reservoir pressure and increase oil recovery. Consequently, gas production often lar exceeds sales. More detailed data are presented in Appendices II and IV. 


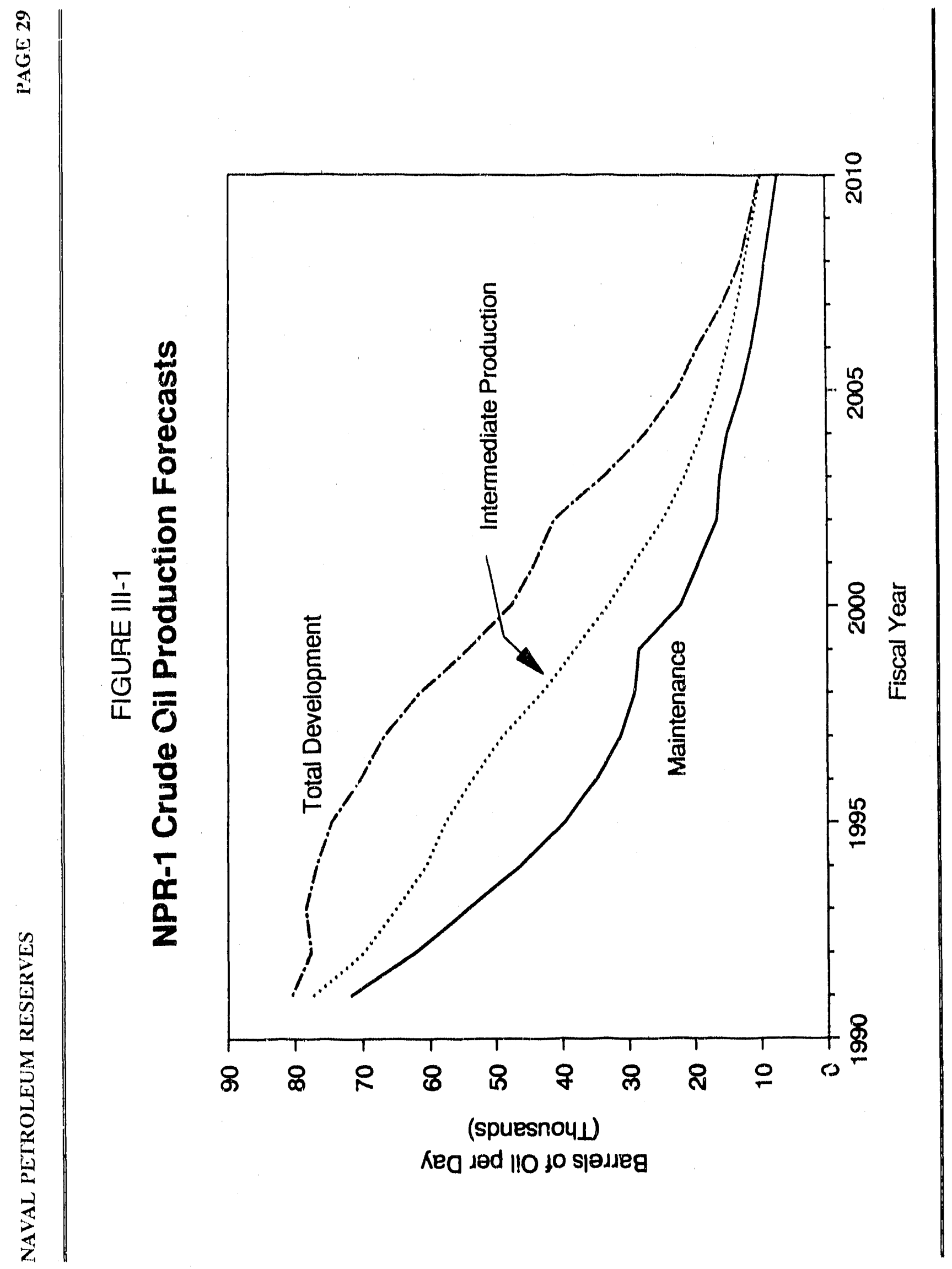




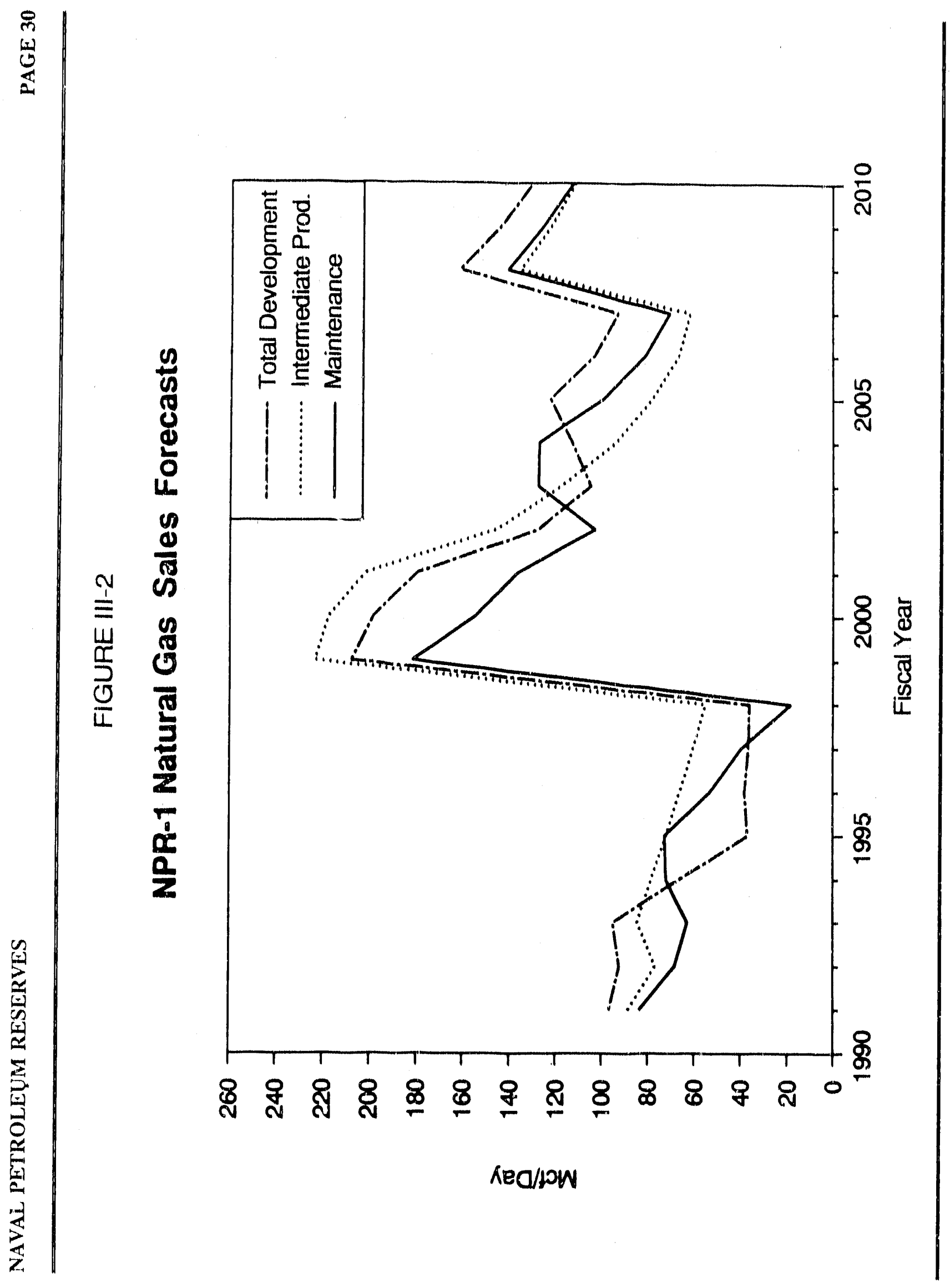




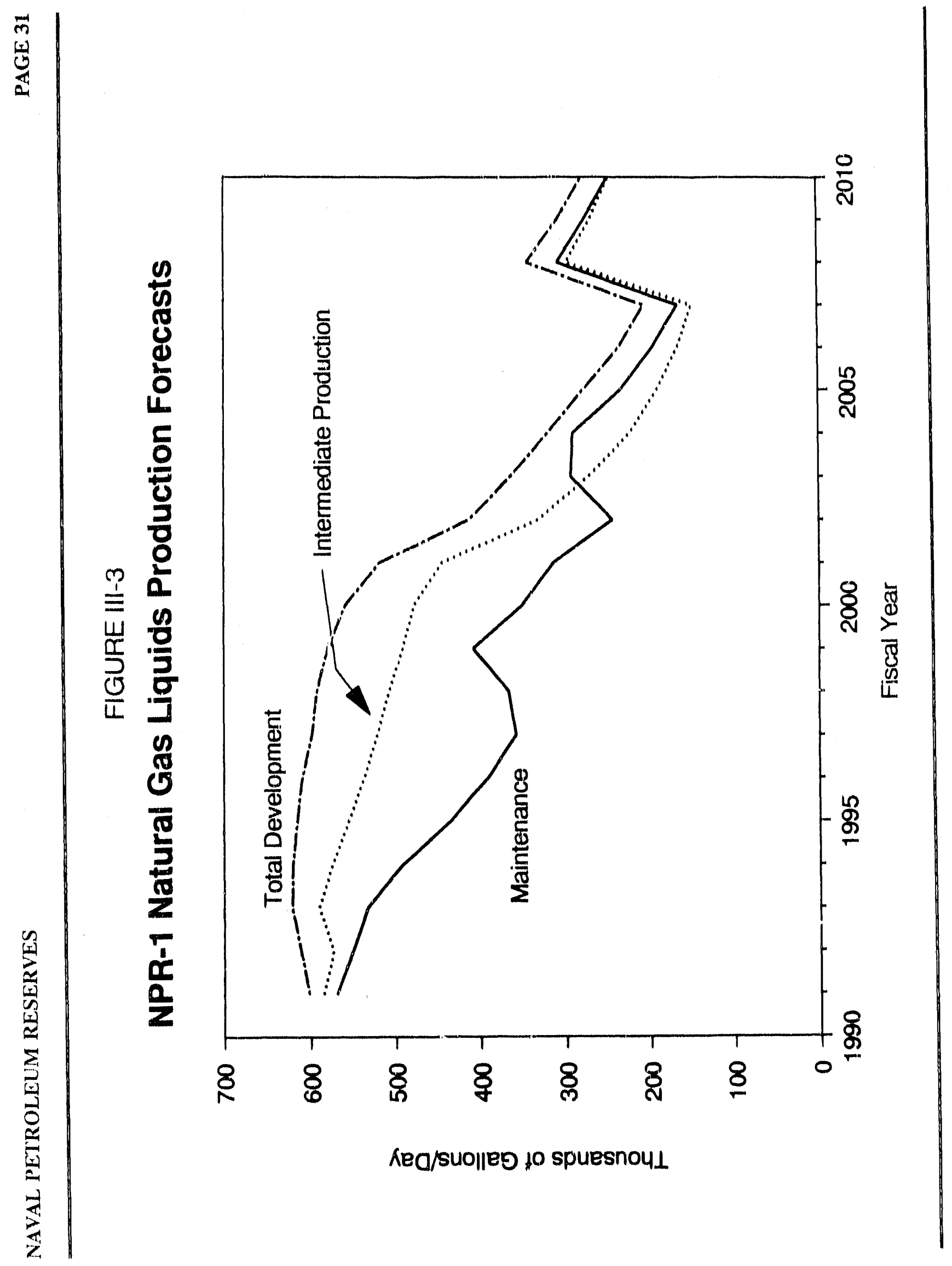




\section{SIIU'T-IN}

\section{OPLRATIONS UNDER SHUT'IN}

As implied in the 1976 Act, the shut-in production level is production that is neccssary for the protection, eonservation, testing, and maintenance of the NPR reservoirs. Operation and maintenance under shut-in would include the following activities:

- implementing a rotating test program to ensure proper reservoir management and well maintenance;

- injecting gas into the reservoirs to maintain pressure and prevent loss ol recoverable oil due to water influx;

- producing NPR-1 at a level sufficient to prevent migration of reserves;

- repairing and maintaining lacilities; and

- maintaining environmental permits.

\section{SHUTTING IN PRODUCIION}

Shutting in production at NPR-1 involves considerable speculation about the subsequent behavior of the sil and gas reservoirs. Since it is highly unusual in the industry for large, profitable, complex oil fields to drastically curtail production, the engineering estimates involved in this case are much more speculative than for the continued production cases. Individual reservoir strategies would need to be devised as the field was shutting in, and the relative expense of monitoring well pertormance would be greater. The 1976 Act requires that the Government's interest in the field be: fully protected and that proper conservation of the resource be practiced. A fuller discussion of the approach to managing a shut-in is in Appendix III.

Shutting in the Reserves would require approximately one year starting in April 1991. Thetal production would be redueed quickly to a low level, followed by a gradual shutdown of selected 
remaining oil and gas wells, Alter well shut-down, most gas separation plants, compressors, lank

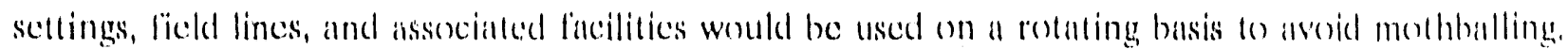

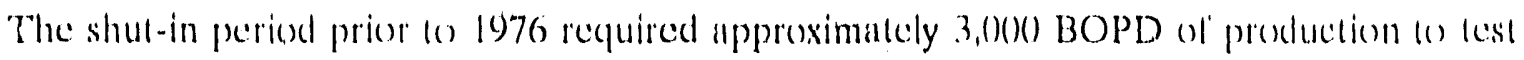
wells, maintain injection, and protect against drainage into wells outside the Reserve. Since there are currently many more wells in the Reserve than in 1976, a higher minimum preduction level is required to maintain the reservoirs and the wells.

"The projected shut-in 'evels of crude oil, natural gas, and natural gas liequids production and the asseriated costs in this analysis are DOE estimates. For the next three years, which are under consideration for the current clecision, the estimated Government share of petroleum production levels under shut-in are 57,490 BOPD of crude oil in 1991;24,960 BOPD in 1992; 12,(0)() BOPD in 1993: and 10,200 BOPD in 1994. The natural gas production estimales for a shut-in NPR-1 are 277,(66) MCF/D in 1991; 117,312 MCF/D in 1992; 56,4(K) MCF/D in 1993; and 47,94() MCF/D) in 1994. Natural gas liquids production estimates for shut-in are 471,446 GAL/D in 1991; 199,(618 GAL/D in 1992; 95,970) GAL/D in 1993; and 81,575 GAL/D in 1994. The annual cost estimates for shut-in production of the total lield in 1990 dollars are $\$ 187.7$ million in $1991, \$ 82.5$ million in 1992 , $\$ 49.1$ million in 1993, and $\$ 42.8$ million in 1994. An indelinite shut-in, as annlyzed in this study, reduces production to minimal levels and remains there until a national defense emergency requires its resumption, as opposed to a perpetual shut-in, where the NPR-1 would minimize production without resumption.

\section{REI'URN TO PROIDUCTYON}

In the event of' a national emergency, it may be necessary to evaluate the possibility of reopening NPR-1. There is no existing law that authorizes intermediate production restart at NPR-1 from a shut-in status unless a national delense need is found by the secretary and approved by the President, and Congress authorizes production in a joint resolution. National defense is cielined under existing law as including the "needs of, and the planning and preparedness to meet, essential defense, industrial, and military emergency energy requirements relative to the national salety, 
welfare, and economy, particularly resulting from loreign military of economic actions". "Therefore, in the absenee of a national detense need, new legislation would be required to increase NPR-1 crude oil production to an MER level from the shut-in level.

This study assume; that production would resume in the year $20(0)$ if the shut-in option were adopted, either as a result of a new policy and legislative decision or in response to a supply emergency. As discussed in the following section, an alternative price path has been constructed as a possible simulation of emergency market conditions.

For purposes of this investigation, it wass assitumed that NPR-1 production could be increased slowly from the shut-in level within a low days after the beginning of an emergency and that production could be expanded gradually until maximum production was reached within 12 to 18 months. This is an extremely optimistic assumption because it implies that there would be sufficient foreknowledge of an interruption to permit legislative, budgetary, and eontractual arrangements to be in place at the time an emergency began. A hypothetical national oil supply shortfall was postulated to occur in 20k), which would trigger the resumption of NPR-1 production by 2001 . It is expected that some reservoirs that are produced at very low levels might actually exceed their current levels briclly when returned to MER by 2001 , resulting in a temporary production "bulge". Figure III-4 shows the Shut-In Case with resumption at MER contrasted with the Intermediate Production Case.

A return to production could be significantly delayed if the level of environmental operating permits currently held by NPR-1 was not maintained during shut-in. NPR-1 now maintains over 6.30) air quality permits on the lederal, state and local levels at a cost of about $\$ 50(0,0)(0)$ a year. NPR-I's air and water quality compliance and endangered species program require extensive lime and planning. In order that the Reserve be able to respond to a return to production in an emergency, NPR-1 would have to maintain its envirormental permits and programs during a shut-in period at the level required at MER production. 
$n$
0
0
0

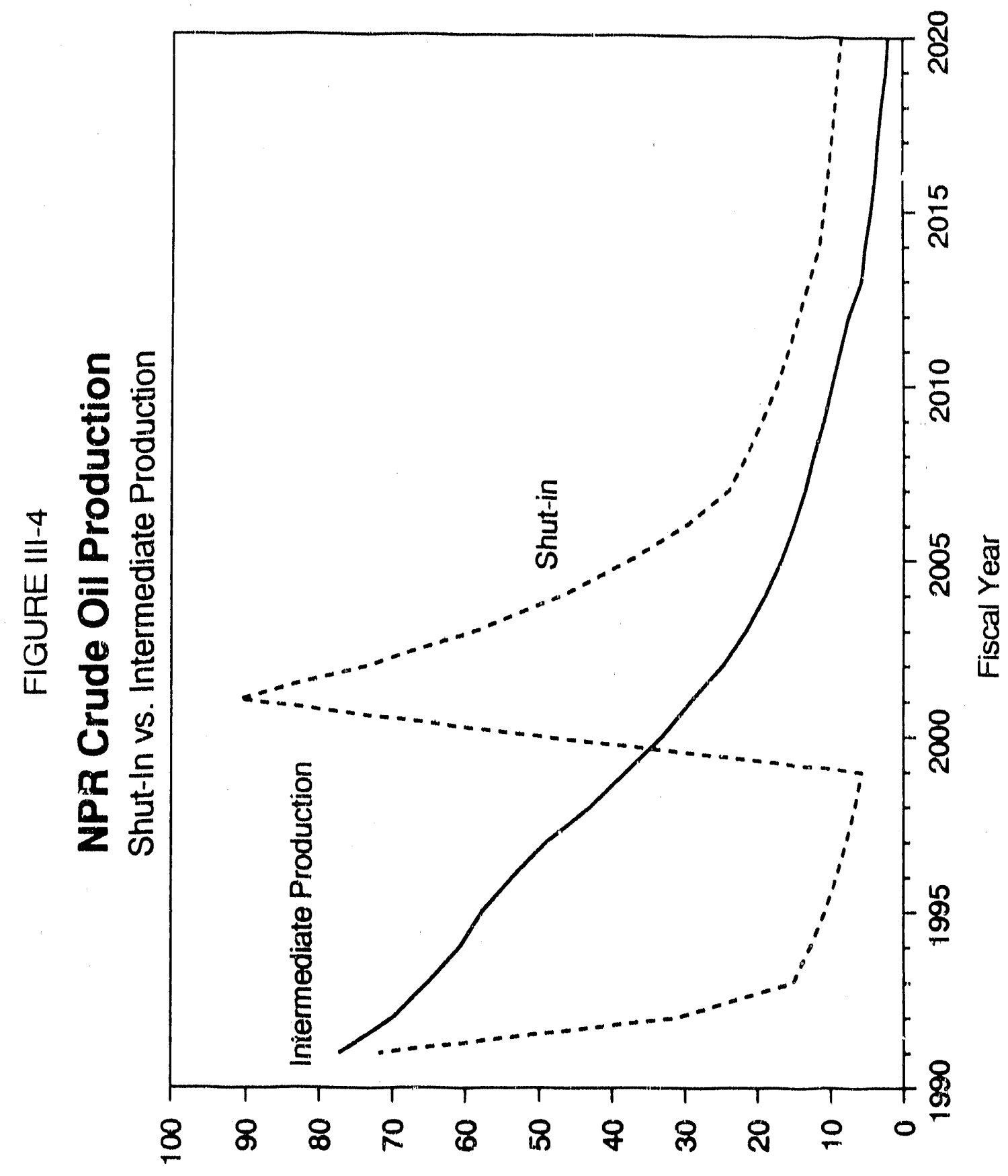

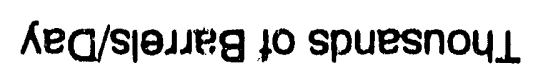




\section{E. PETROLEUM PRICE ASSUMP'IIONS}

\section{NORMAL MARKET CONDITIONS}

Four different petroleum price cases are used in this analysis. First, the price assumptions associated with the President's FY 1991 budget are used. These are termed "OMB" in the text. The budget document provides price assumptions for only five years; the longer-term projections were derived by extrapolating from near-term rates of growth. Also, the Energy Information Administration's (EIA) world oil price paths from the Annual Energy Outlook 1990 (AEO 90) are used to derive representative Base, High, and Low revenue streams through 2020, which is near the economic limit for several reservoirs at NPR-1. The AEO 90 projections were published for the period through 2010; for this study, these projections were extended to subsequent years by applying the growth rates prevailing at the end of the published series. All price sireams are also adjusted to reflect the California regional market. ${ }^{12}$

Figures III-5, III-6, III-7, and III-8 compare the different oil, natural gas, and propane price paths used in estimating the range of revenues from NPR-1 that could result from different future market conditions.

Two primary crude streams are produced at NPR-1:

- $\quad$ Stevens Zone: API Gravity 35 degrees, Sulfur content 0.5 percent;

- Shallow Oil Zone: API Gravity 25 degrees, Sulfur content 0.7 percent.

These are lighter and swecter crudes than are produced in neighboring fields in Kern County, California, and compare well with mid-continent crudes that are good gasoline and heating oil producers in sophisticated refineries. They are also higher quality crudes than generally are expected to be available to the US from the world oil market during the period 1990-2010 and should

${ }^{12}$ Fur comparison, NPR-1 average year-to-date prices through May 1990 were: crude oil $\$ 18.98 /$ barrel; natural gas $-\$ 2.55 / \mathrm{MMBTU}$; propane - $\$ 0.36 /$ gallon; butane $-\$ 0.30 /$ gallon; and natural gasoline $-\$ 0.47 /$ gallon. 


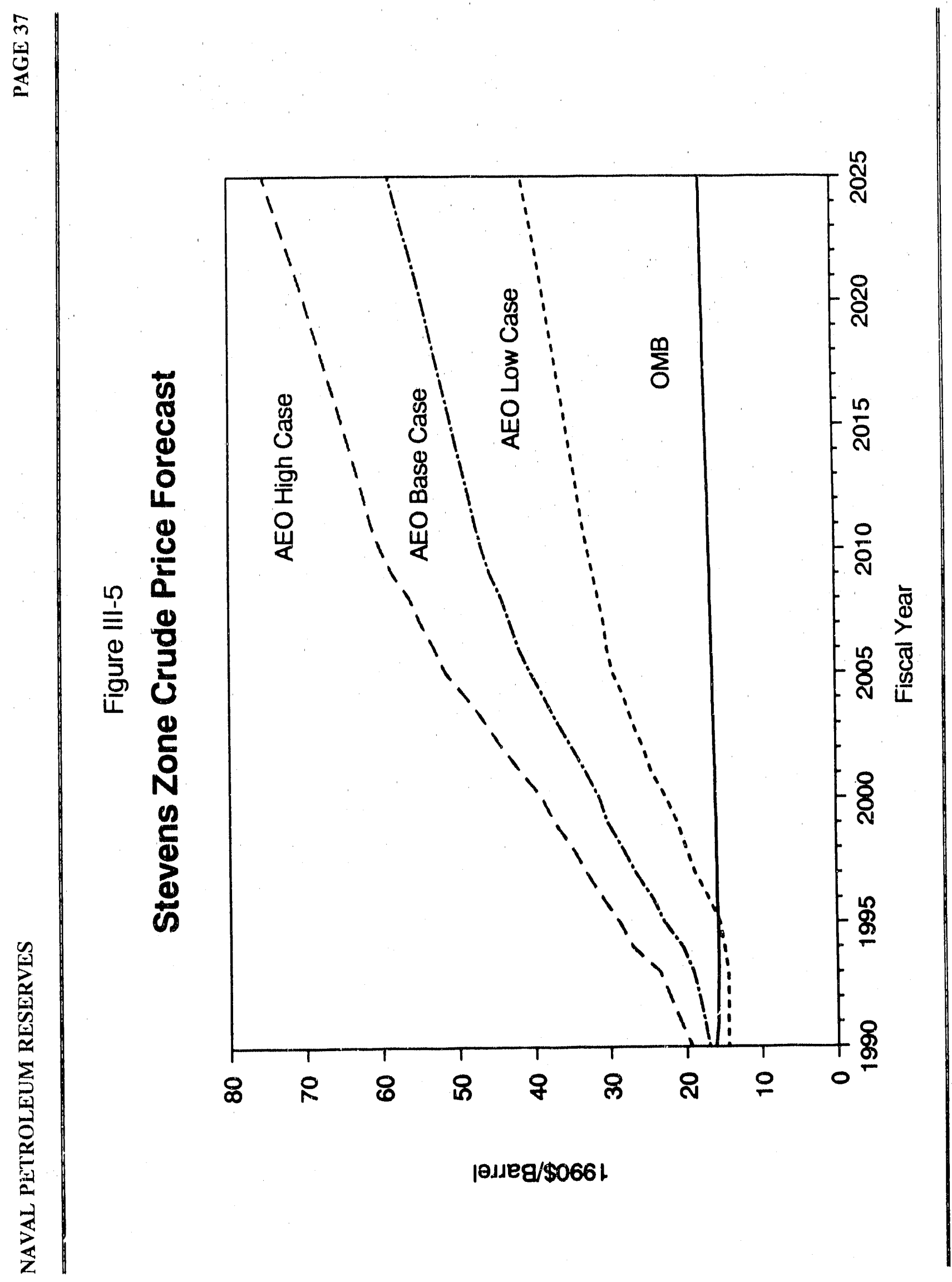




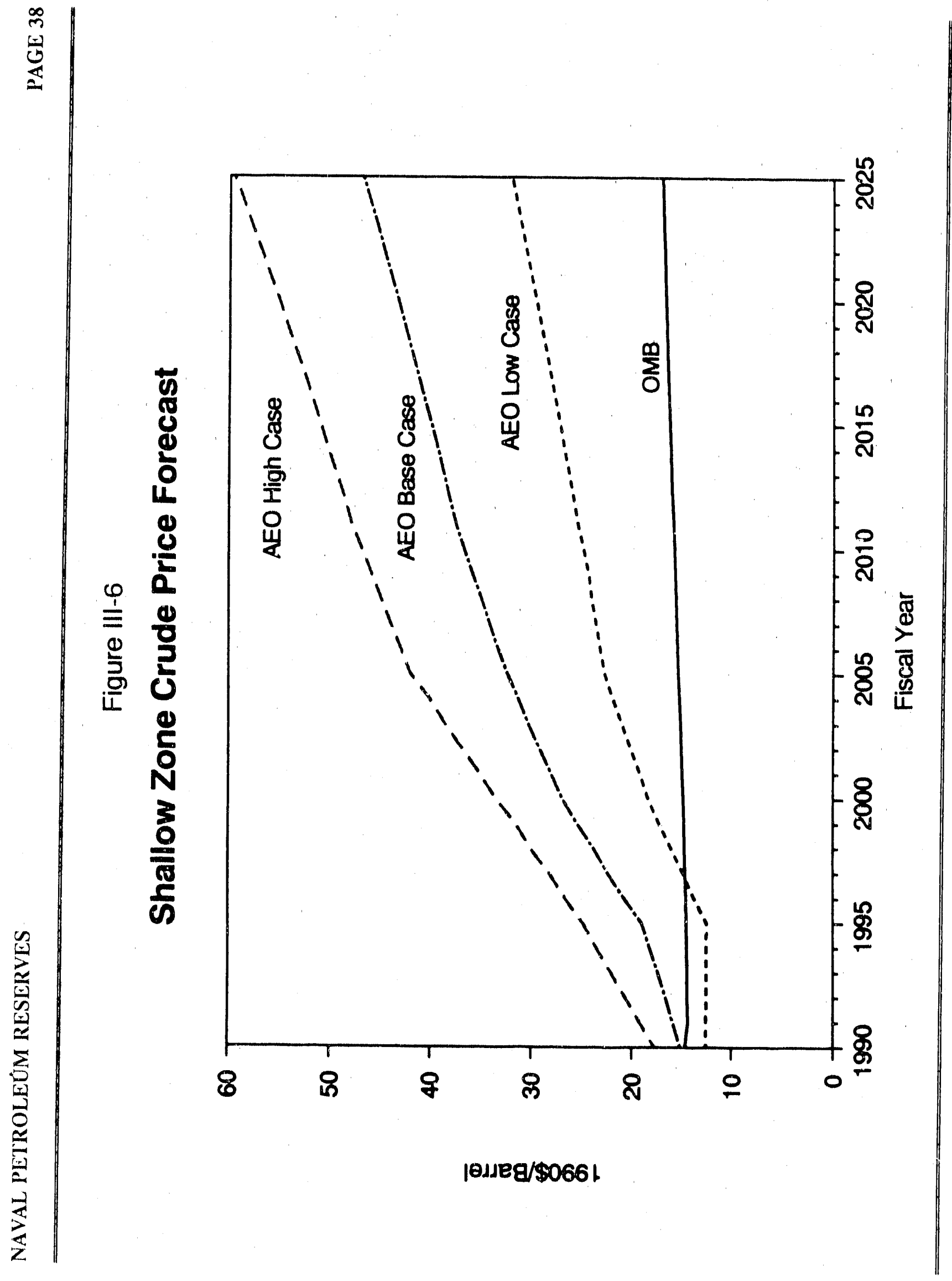


है

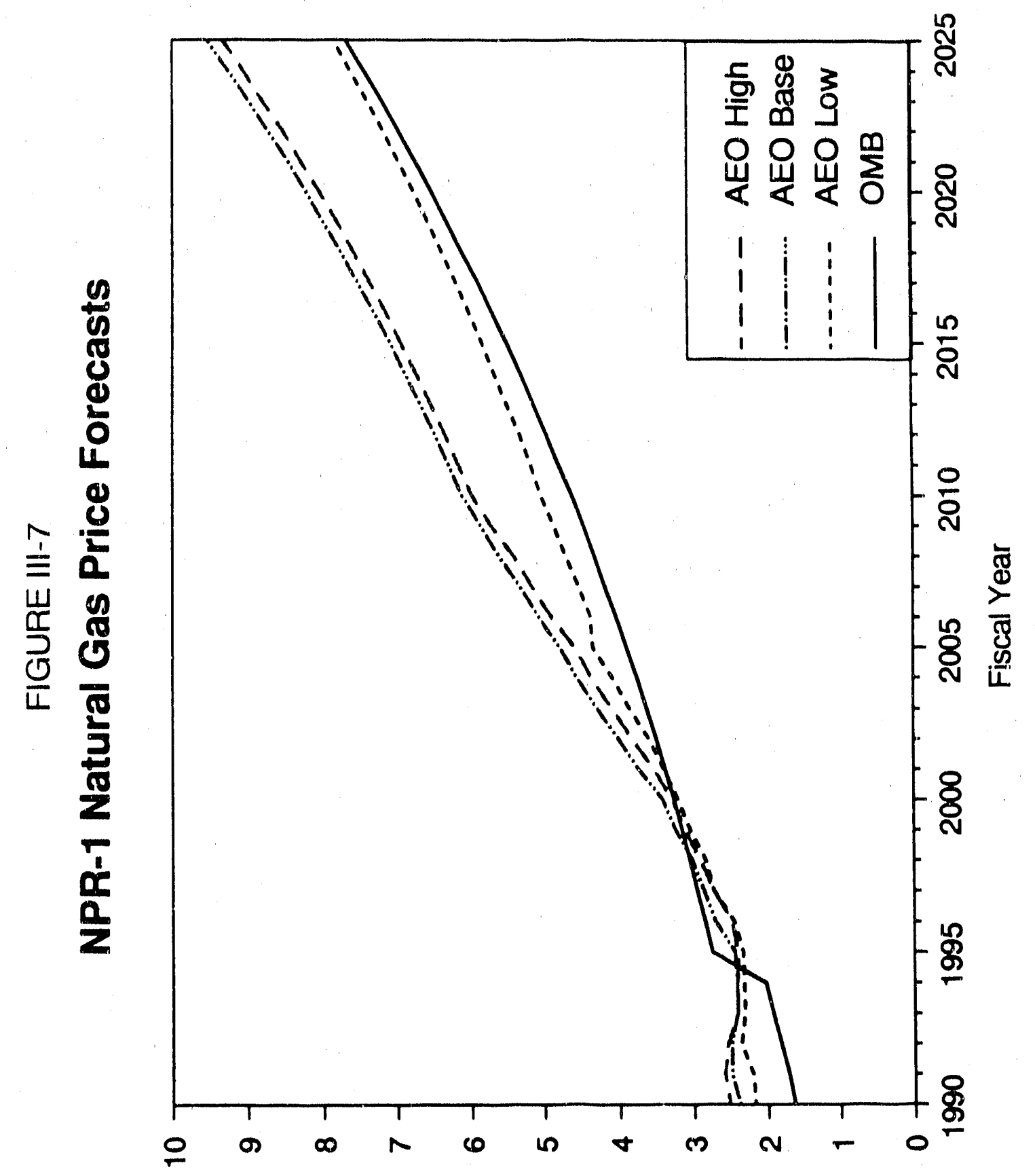

$10 W / \$ 0661$ 


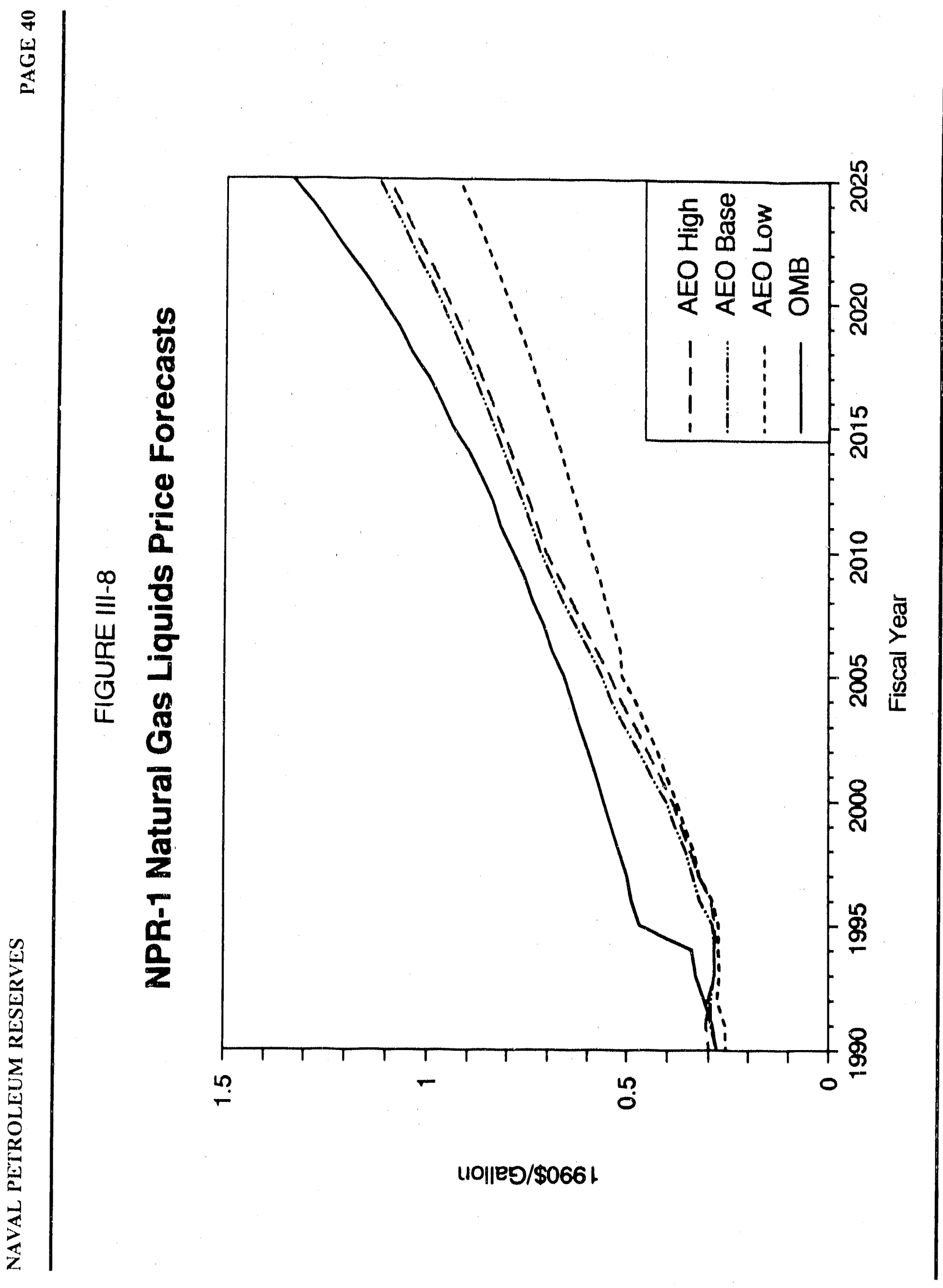


therefore have a higher refining and market value than the average Mideast crudes imported to the US.

The baseline price case uses real prices or prices that are expected to occur in succeceding years but with inflation factored out beyond the base year of 1990. Inflation likewise affects costs of operation, and these costs are adjusted as well. Real prices then become a foreast of luture value in 1990 terms.

\section{OIL SUPPLY DISRUP'TION}

A critical national defense emergency, such as a major oil supply disruption, could trigger the use of the NPR if it were being used as a discretionary supply in the event of a global or regional shortfall. An analysis based on a US supply emergency and the Shut-In Case was run to illustrate some of the price effects and to reevaluate the net present value (NPV) of net economic bencfits. It was assumed that there was an international oil supply disruption in the year 2000 that caused prices to increase, in real dollars, to more than twice the level in the AEO Base Case price path. In this case, it was assumed that prices would subsequently decline; by the end of three years, the original AEO Base Case price path would be regained. Figure III-9 illustrates this effect for the Stevens Zone price forecast. 


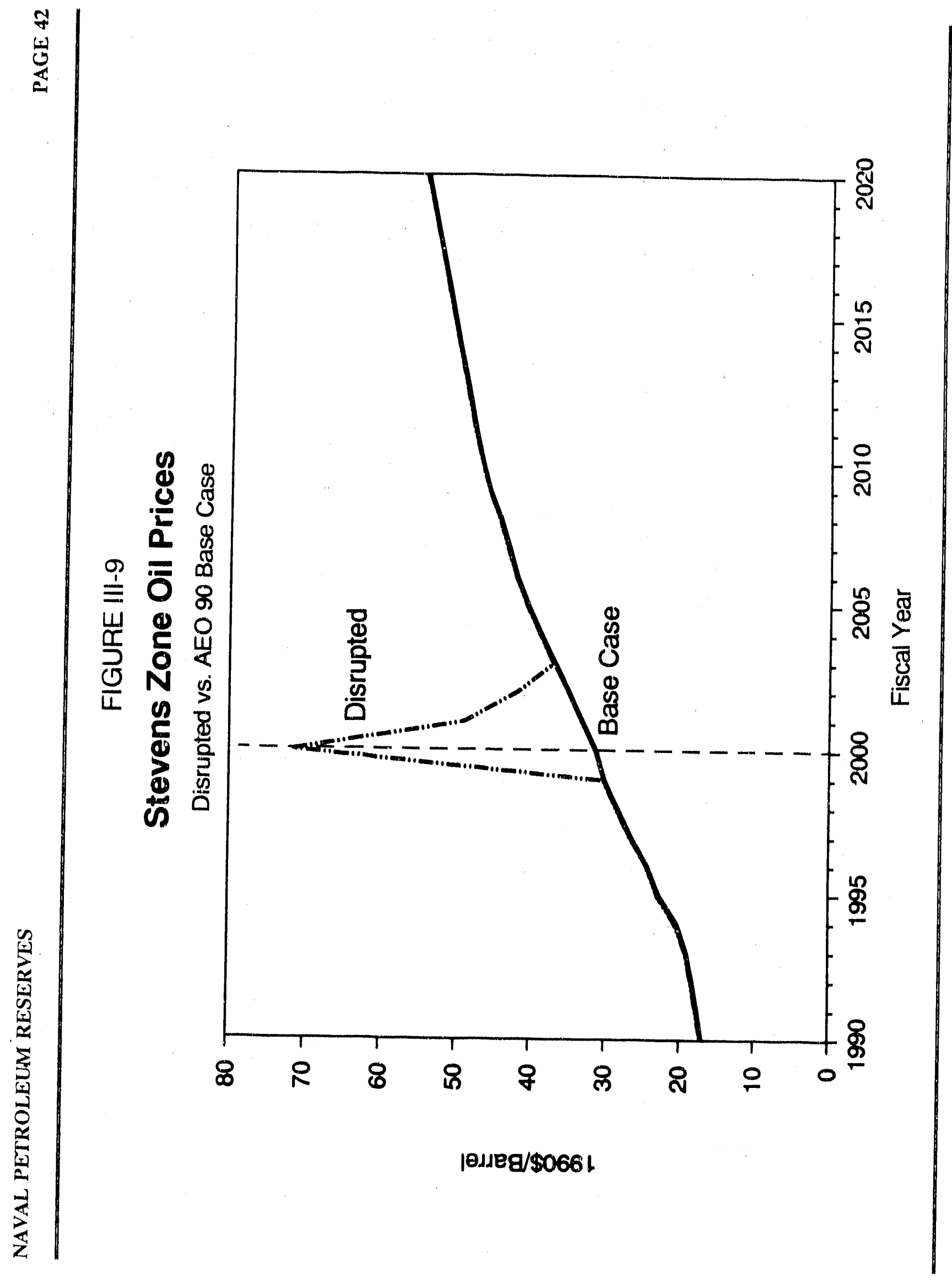




\section{[1. COMPARISON OF SHUT-IN AND IN'TERMEDIA'TE P'RODUC'TION CASES}

\section{NATIONAL ECONOMIC IMPAC'TS}

The direct impact of Elk Hills production on the economy can be characterized as the difference between the value of the hydrocarbons produced for use in the oil market and the costs of such production. Both the production value and the associated costs are affected by the continued production.

A major feature of the decision is that the Shut-In Case would defer both production and costs for an extended period, until a second decision was made to resume production. The analysis uses discounted present value techniques, employing a 10 percent real discount rate, to illustrate these timing effects. Costs are deducted from the sales value of production to derive a net present value (NPV) of decision alternatives under a variety of price assumptions.

Table III-3 presents the results of this analysis for various oil price forecasts under the nodisruption circumstances, using the Intermediate Production Case presented earlier in this chapter. NPV is calculated through 2020 only, since some price cases produce negative cash flows in later years.

'TABLE III-3

ELK HLLS ECONOMIC VALUE, 1991-2020

(NPV in Millions of $\$ 199()$ )

$\begin{array}{lcr}\text { Price Case } & \text { Intermediate Production } & \text { Shut-In } \\ {2,(023} &{ } \\{\text { OMB }} &{2,495} &{1,257} \\{\text { AEO-Low }} &{3,572} &{2,039} \\{\text { AEO-Base }} &{4,373} &{2,929} \\{\text { AEO-High }} &{ } &{3,599}\end{array}$


Under all four sets of price assumptions, the net present value of continued production substantially exceceds the net present value of shutting in the field. This analysis includes not only the direct effects on the Federal budget from changes in the value of Federal ownership interests in the field but also the effects of a loss of Chevron's share of production. Table III-4 provides the direct Federal Budget impacts associated with selected price cases.

TABLE III-4

I'EDERAL BUI)GE'I IMPAC'IS, 1991-2020

(NPV in Millions of $\$ 199()$ )

$$
\text { Intermediate Production }{ }^{13} \quad \text { Shut-In } \quad \text { Difference }
$$

\section{OMB Price Case}

$\begin{array}{lrrr}\text { U.S. Revenues } & 2,788 & 1,920 & 868 \\ \text { Costs } & 1,244 & 1,011 & 233 \\ \text { NPV } & 1,544 & 909 & 635\end{array}$

AEO-Base Case

$\begin{array}{llll}\text { U.S. Revenues } & 4,028 & 3,258 & 770 \\ \text { Costs } & 1,273 & 1,011 & 262 \\ \text { NPV } & 2,756 & 2,247 & 509\end{array}$

As illustrated in Table III-4, the shut-in option would greatly reduce the budget benefits of Elk Hills.

${ }^{13}$ The calculations summarized in this table assume that the field would be shut in when its net revenue stream becomes negative and stays negative. The two price paths have different costs under the Intermediate Production Case because net revenues would become negative earlier under the OMB Price Case than under the AEO Base Case. 


\section{Sensitivity Analysis}

Il an cril supply distuption cecurs, there will be an increase in the market value of NPR production. Deferring production until the period of higher market value would ereate the possibility of economic gain. However, as illustrated in Table Ill-5, the NPV of continued production would still be higher than the NPV of' shut-in. (Note that this is an estimate of the market value ol' NPR-1 production: it does not consider the economic benctits ol NPR production.)

\section{T'ABLE $11 \mathrm{I}-5$ \\ NE'T PRLSLIN'T VALUE OI' LLK HILLS \\ (AEO Base Case, Millions of $\$ 1990$ )}

\section{No Disruption}

Intermediale Production

Shut-In

Difference
3,572

2,929

643
Disruption

4,088

3,694

394

The benefits that could accrue from a resumption of production would be delayed considerably and do not provide convincing arguments for utilizing the NPR as a limited strategic reserve. If, for exarnple, an emergency occurred early in 200()-allowing several weeks for the Executive Branch to acquire the budget authority to resume maximum production--total NPR production could increase from approximately $5,700 \mathrm{~b} / \mathrm{d}$ in 1999 to $50,5(0) \mathrm{b} / \mathrm{d}$ within a year. The peak could only be realized in the following year, at nearly $91,0(0) \mathrm{b} / \mathrm{d}$. The lag time could be from $11 / 2$. to 2 years alter the emergency occurred. Thus, it would take an unusual disruption--one of extended duration that occurred with ample forewarning...for the shut-in reserve to be fully used.

Furthermore, the assumption made in this comparison was that such a disruption would be certain to occur. This assumption is not consistent with the Administration's recent assessment of Strategic Petroleum Reserve size alternatives and is used here to illustrate that shut-in would not yield net economic benclits under the most extreme set of assumptions. 


\title{
2. IMPAC'I' ON NA'TIONAL LNLERGYY S'IRA'ILGYY
}

\author{
Impact on Oil Import Lovels
}

If NPR production were shut in, lost production would be replaced by incrensed imports. This would be true not just lor crude ofl but also for lost natural gas and natural gas liquids. Any natural gas or natural gas liquids that would have been sold for public consumption must also be: considered lo be kest luels and must somehow be replaced.

A number of factors eomplicate the matter of calculating the volurne of oil imports that would be reguired to replace lost production at the NPRs. Among these are:

- Usc of diflerent production scenarios (Shut-In, Maintenance, Intermediate, and Total Development Cases);

- Shifting production volumes of different fuels over time (e.g., NPR-1 nalural gas production will rise in later years, as oil production lalls);

- Use of different lactors to convert different fiues to equivalent volumes;

- Difficulty of forecasting substitutability of fuels in the future.

A rough calculation of the need lor additional barrels of oil imports is presented in 'Table 111-7. The lable presents the volumes of NPR-1 production that would have to be replaced by oil imports for the Maintenance, Intermediate, and Total Development Cases from 1991 through 2010. Each column represents the difference in energy production between one of the thee production cases and the Shut-In Case. (Calculations are based on BTU equivalents of imported crude oil, natural gas, and natural gas liquids.) ${ }^{14}$

14 Conversion lacens to barrels of erude oil equivalent (BOE) were derived from thermal conversion factors lound in the Annual Energy Review 1989. Factors used were 5.9 million BTU per barrel for imported crude oil; 1.0 million BTU per mef for natural gas, or a conversion factor of $1 / 5.9$ or .17 to BOE; and 4.2 million BTU per barrel lor natural gas liquids a rough combination of the factors for butane, propane, and natural gasoline, which 
These cases assume that NPR.1 would be shut-In until 2000). Clearly, additional oil imports would be needed if NPR.1 were shut in, but oil import reculurements would be reduced when production was sturted aguin.

T'ABSLE III-7

OIL IMPOR'TS REQUIRLD 'TO RLPLACE LOSIT NPR-1 PRODUC'IION (THOUSANDS OF BARRELS PER DAY OF OIL EQUIVALENT)

\begin{tabular}{|c|c|c|c|}
\hline Yoar & Maintenance & $\begin{array}{l}\text { Intermediate } \\
\text { Production }\end{array}$ & $\begin{array}{c}\text { Total } \\
\text { Development }\end{array}$ \\
\hline 1992. & 37 & 47 & 58 \\
\hline 1993 & 57 & 73 & 88 \\
\hline 1994 & 25 & 70) & 84 \\
\hline 1995 & 47 & 67 & 8() \\
\hline 1996 & 40) & 64 & 77 \\
\hline 1997 & 35 & 59 & 74 \\
\hline 1998 & 31 & 53 & 70 \\
\hline 1999 & 60 & 78 & 93 \\
\hline 2000 & -.33 & -10 & 3 \\
\hline 2001 & .99 & .76 & -64 \\
\hline $20(12$ & .79 & .62 & -48 \\
\hline $20(0) 3$ & -51 & -48 & .36 \\
\hline 20$)(14$ & .34 & -.37 & .23 \\
\hline 2005 & -28 & -29 & .14 \\
\hline 20016 & .21 & $-2,0$ & .8 \\
\hline 20$)(7$ & -15 & -13 & -4 \\
\hline 20018 & 3 & 5 & 11 \\
\hline 20019 & 2 & 4 & 8 \\
\hline 2010 & 1 & 4 & 7 \\
\hline
\end{tabular}

If world oil consumption increases in the 1990)'s time period and domestic oil production decreases, as projected in the National Energy Strategy Interim Report of 1990), the lack of NPR-1 production could have a small impact on world oil prices in the same period. ${ }^{1.5}$ The precise impact ol NPR-1 production on workd oil prices cannot be readily quantified, however, because world oil

are produced at NPR-1), or a conversion factor of .72 to BOE.

1.5 Interim Report, National Energy Strategy; U.S. Department of Energy; DOSE/S-())66P; April 19)(). 
prices will be aflected by much more significant lactors such as the mate of economic growth, the actions of OPEC members that affect supply levels, and changes in nor. OPEC oil production and in non-esil encrgy production. For the nation as a whole, losing NPR-1 production woukd probably result in a very small change in prices compared with changes brought about by other factors that could alfect world oil prices.

\section{Improving Energy Security}

Shutting in NPR-1 so that it could be used as an emergency oil reserve could cinly reduce the inpact of a long oil supply disruption very slightly. Because returning NPR-1 to full production would require 6 in 12 months or more, it would have little benelit for disruptions of less than one year's duration.

The following table compares the total sales of Elk Hills during the period 2000-20044 inclusive under the Intermediate Production Case and a Shut-In Case that assumes resumption of production in $2(x)()$.

TABLE III.8 ELK IIILLS PRODUCTION (2000-2004)

\begin{tabular}{crr} 
Intermediate Production & Shut-In & Difference \\
\cline { 1 - 2 } & & \\
46.5 & 116.5 & 70.0 \\
283.5 & 341.6 & 58.2 \\
$\frac{.7}{196.8}$ & $\frac{1.0}{192.4}$ & $\frac{.3}{85.6}$
\end{tabular}

Crucle Oil (MMB)

Nallural Gals Silles (BCF)

Natural Gas Liquids (Billion Gallons)

Total (MMBOE)

\author{
Gallons)
}

$$
\text { Intermediate Production }
$$$$
46.5
$$$$
283.5
$$$$
106.8
$$

As illustrated in Table III-7, to achieve this 85.6 MMBOE increase in Elk Hills production. during the period of a presumed supply disruption starting in 200() would require increasing U.S. oil imports by roughly 511 MMBOE during the period 1992 through 1999. (Oil equivilent to be replaced by oil imports under the Intermediate Production Case from 1092-1999.) 
A short-arm crude oil supply shortage can be more effectively met by the development and drawdown of the Straltegic Petroleum Reserve. Under current plans, the SPR will contain 750 million barrels of crude oil when completed. Mid-1990) SPR crude oil inventory is now nearly 60)( million barrels. It is estimated that a 750 million barrel SPR will be capable of drawing down and distributing its crude oil inventory at the rate of 4.5 million BOPD. This rate is substantially greater than the current crude oil production rate at NPR-1. In sum, a shut-in NPR-1 would not be an elfective or efficient means of providing oil storage for use in an oil supply disruption because of the relatively low rate at which oil could be produced from the Reserve, the length of time required to start production after the liekl has been shut in, and the large amount of production that would need to be deferred relative to the quantity of oil made available in an emergency. 


\section{LOCAL AND REGIONAL IMPACTS OF NPR-1 SHUT-IN}

\section{Consumers}

Shutting in NPR-1 would likely result in an increase in the cost of refined products in the $s$ in Joaquin Valley of several cents per gallon. The supply of locally produced products would decline and the price of the products would rise. Some local refineries might close or curtail their production as the supply of feedstocks declines. Furthermore the price of available teedstocks should climb because there would be less competition and because transportation costs to bring in crude oil from Los Angeles would increase. Also, San Joaquin Valley refiners may have to modify their plants to refine heavy crude oil. These additional costs for crude oil, transportation, and equipment would be passed on to consumers in the form of higher prices. As the supply of locally produced peiroleum products declines, retailers will import more products from outside the region. The increase in transportation expense for these products would also be passed on to consumers.

\section{Employees at NPR-1}

Approximately 1,300 persons, including Government personnel, support staff, and employees of Bechtel Petroleum Operations, Inc., Chevron U.S.A. Inc., and numerous subcontractors are currently employed in NPR-1 activities. If the Reserve were shut-in, staffing would decline, probably to less than half of the current level. Rough projections of staffing levels under the Shut-In Case for FY 1991 through FY 1994 are presented in Table III-9. These estimates are based on the assumption that the field would have to be maintained so that it could reopen someday. Reservoirs would have to be monitored and maintained, and all environmental and other operating permits would have to be kept current. In addition to the loss of direct employment, indirect unemployment would result due to the drop in the general need for goods and services. 
TABLE III-9

NPR-1 RELATED STAFFING FOR SHUT'IN

\section{Organization}

Government (Including Support)

Bechtel Petroleum Operations, Inc.

Chevron U.S.A. Inc.

Subcontractors

EG\&G

TOTAL
Staffing Level

FY 1991 FY 1992 FY 1993 FY 1994

\begin{tabular}{rrrr}
58 & 56 & 52 & 46 \\
733 & 718 & 335 & 335 \\
23 & 25 & 25 & 25 \\
450 & 150 & 150 & 150 \\
16 & 16 & 16 & 16 \\
\hline & & & \\
1280 & 965 & 578 & 572
\end{tabular}

\section{Independent Refiners}

Independent refiners in southern California purchase Elk Hills light crude oil directly from the Government or indirectly through crude oil traders. Some of this oil is moved by pipeline to independent refiners in the Bakersfield area, and some is mixed with heavier crude oils from the San Joaquin Valley and transported to the Los Angeles Basin through the Four Corners Pipe Line Company's lines 1 and 63.

Several small independent refiners in the Bakersfield area, including Kern Oil and Refining Company and Sunland Refining Company (a subsidiary of Lunday-Thagaard Company), depend on Elk Hills light crude for their refineries. Elk Hills is the largest block of crude oil production that is not controlled by a major oil company and is virtually the only source of light crude oil run by these refineries. They are designed to convert light crude oil to gasoline, military and commercial jet fuel, diesel fuel, and fuel oil. Many of them would not be able to acquire suitable replacement crude oil if Elk Hills were shut in. Figure III-10 is a pipeline map that shows refineries and pipeline links in the Bakersfield-Los Angeles area. 


\section{FIGURE III-10}

\section{NAVAL PETROLEUM RESERVE NUMBER 1}

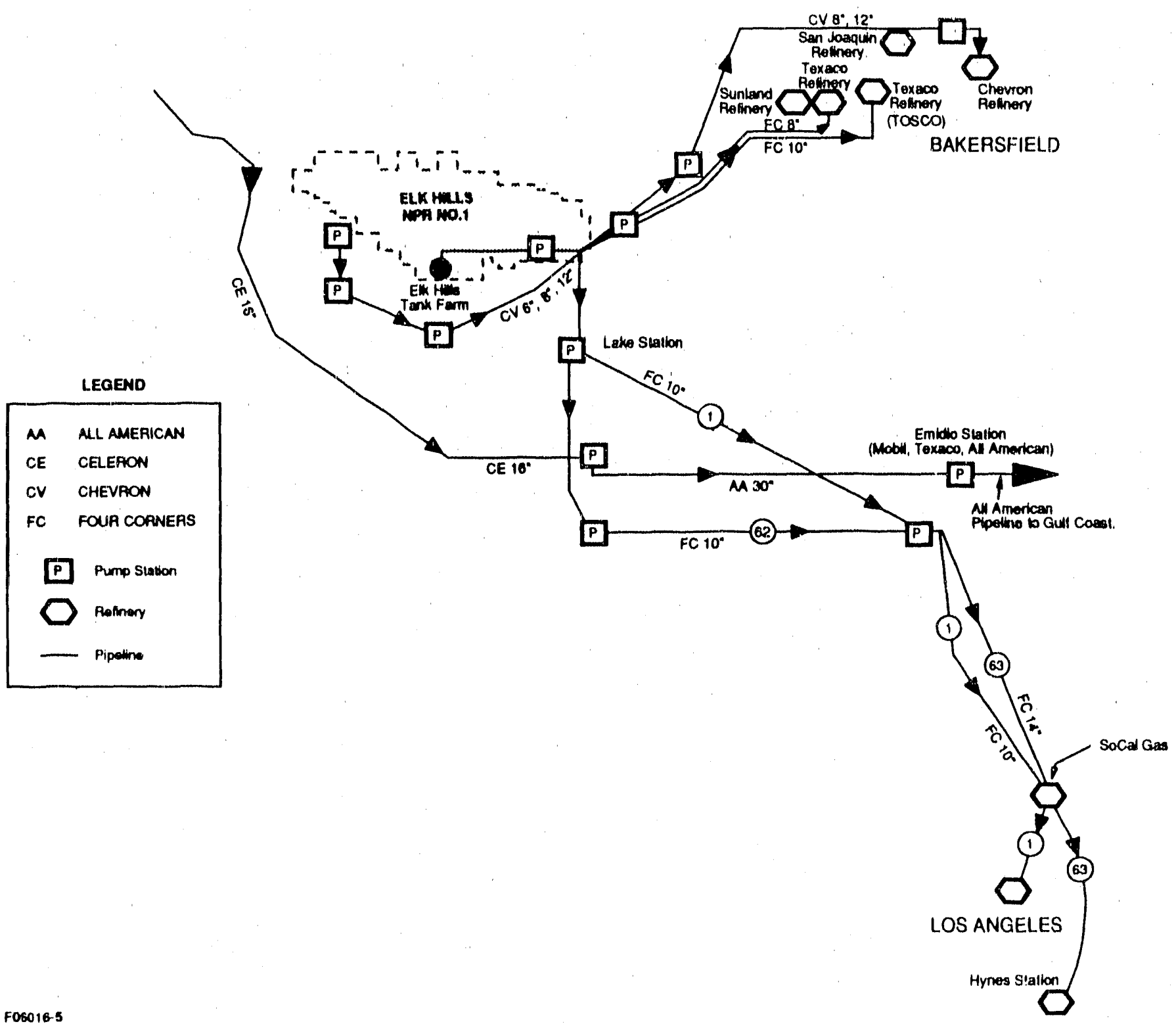


The alternative sources of crude oil that would be available to independent Bakersfield refineries are San Joaquin Valley heavy crude oil. Alaska North Slope (ANS) crude oil, various foreign crudes and, perhaps, Outer Continental Shelf (OCS) crude oil. Crude oil from Elk Hills' Stevens Zone averages about $36^{\circ}$ API, whereas local heavy crude oils are about $13^{\circ}$ API and ANS is $27^{\circ}$ API. If OCS oil is available, it is expected to be about $19^{\circ}$ API and to contain 3.5 to 4.0 percent sulfur. Conversion of the refineries that currently use Elk Hills crude oil to heavier crude oil would be expensive, and environmental permitting requirements might make it impossible in some cases.

During the past few years, the light crude oil production that exists in the San Joaquin Valley has declined at a faster rate than heavy crude oil production. In view of this change in the balance between light and heavy crudes, NPR-1 production is even more essential for the southern California market. Consequently, a shut-in of NPR-1 would disrupt the refining industry in the San Joaquin Valley. While most of the refiners believe that they could adjust to a gradual change in crude oil quality, a sudden change that requires a large capital investment could put them out of business.

The only way that Bakersfield area refiners can currently receive ANS crude oil is by truck, since no pipelines run from ports to Bakersfield. (The only common carrier pipeline in the area, Four Corners Pipe Line, carries crude oil from Bakersfield to the Los Angeles Basin.) In order for Bakersfield refineries to receive ANS crude oil, it would have to be terminalled and trucked to Bakersfield at a cost estimated to be about $\$ 2.15$ per barrel. The combination of increased transportation costs, lower product value and increased processing cost (because of the additional capital investment required) would make these refineries noncompetitive.

The approximately 20,000-30,000 BOPD of Elk Hills crude oil that go to the Los Angeles Basin are shipped by Four Corners Pipeline as a blend of light and heavy crude oils with a gravity of about $27^{\circ} \mathrm{API}$. It is distributed to several major and independent refiners in the Los Angeles Basin. 
The independent refiners in the Los Angeles Basin that currently use Elk Hills crude oil also process other crudes, such as ANS or foreign. ANS crude oil has about the same gravity as the mix that comes through the Four Corners pipeline and, of course, imported crude oil can have various characteristics. The main concern of independent refiners in the Basin is that an Elk. Hills shut-in would raise their crude oil acquisition costs, while the major oil companies' crude oil acquisition costs would not change. Accordingly, independent oil refiners in the Basin would become less competitive.

The refining segment of the California petroleum industry is concentrated and, because it is somewhat geographically isolated, it is not influenced to a great extent by refining activity outside California. The impact of changes within this concentrated market, therefore, is often significant, even if the changes are small. The top seven refiners, all major refiners, account for about 80 percent of the refining capacity in California. The remaining 20 percent of refining capacity is shared equally between other integrated oil companies and independent refiners. Together, they provide a substantial additional competitive element in the market.

Historically, independent refiners have bought a large volume of NPR-1 production from DOE. The small independent refiners in the San Joaquin Valley are heavily dependent upon NPR-1 production as a secure and independent source of supply. These refiners would probably close their refineries permanently if NPR-1 were shut in. The loss of this refining capacity might not be significant in a more competitive market, but this loss would pose a serious concern in the highly concentrated California market.

The San Joaquin Valley independent refiners that would suffer the largest negative impact from the shut in of NPR-1 have a total of roughly 400 to 500 employees. If those refineries closed, those jobs would be eliminated. In addition, an undetermined number of jobs may be eliminated from Los Angeles Basin refineries that could not compete at the higher prices of crude oil expected to prevail after shut-in. Some of the refiners may be able to modify their plants to handle increased amounts of heavy oil. Since individual refinery economic data are not available, it is impossible to determine precisely how the refiners would adjust to a shut in of NPR-1. 


\section{Independent Producers}

Most independent oil producers in the southern San Joaquin Valley produce heavy crude oil. Those producers that are not connected to a heated pipeline owned by one of the major oil companies have only two options for transporting their oil to a refinery: two unheated Four Corners pipelines and tank trucks.

Currently, Four Corners Pipeline will not ship a crude oil or a blend of crude oils that has an average gravity of less than $27^{\circ}$ API. About two barrels of Elk Hills crude must be blended with one barrel of heavy local crude to make an acceptable mixture. If Elk Hills were shut in, the state's largest crude oil source not owned by a major producer would be reduced. The supply of light crude would be reduced, and Four Corners would have to move a thicker oil. This would result in a lower operating rate and would force Four Corners to increase tariffs to cover its costs.

Some heavy crude currently moves from San Joaquin Valley producers to refiners by truck. Asphalt refiners need a heavy crude as a feedstock and prefer their oil undiluted by the Elk Hills crude. However, moving crude oil by iruck is more expensive than moving it by pipeline. The cost to move crude oil from Bakersfield to the Los Angeles Basin is about $\$ 0.55 / \mathrm{bb}$ by pipeline and $\$ 2.15 / \mathrm{bbl}$ by truck.

Some of the natural gas currently produced at Elk Hills is used to produced steam for enhanced recovery of heavy crude oil from other oil fields. If this source of natural gas cannot be replaced because of pipeline capacity or if the natural gas were only available at a higher price, recovery of heavy crude oil by EOR might decline.

\section{Four Corners Pipe Line Company}

The Four Corners Pipe Line Company is the only common carrier pipeline available to move southern San Joaquin Valley crude oil to refineries in Bakersfield and the Los Angeles Basin. As 
noted in Figure 11I-10, Four Corners carries crude oil from Elk Hills to three refineries in Bakerstield and has two pipelines, Line 1 and Line 63, that go to refineries in the Los Angeles area.

Four Corners currently requires shippers to nominate crude oil with a minimum average gravity of $27^{\circ}$ API. Shippers can deliver heavy crude to Four Corners' Lake Station, where the company maintains several mix tanks in which crude oils of different gravities can be blended until the average gravity meets the $27^{\circ}$ API standard. Four Corners then ships the blended crude oil through its pipelines. Four Corners also accepts crude oil at several other points along its pipelines; however, at these points, the crude delivered must be a minimum of $27^{\circ}$ API. Shippers may also deliver their oil to custom blenders who will mix the crude oils to the required standard and deliver the blend to the pipelines. The pipeline has a capacity of $125,000 \mathrm{BOPD}$ of $27^{\circ} \mathrm{API}$ crude oil but could move smaller volumes of heavier oil, and a loss of Elk Hills crude oil would reduce the API gravity of the oil in the Four Corners system.

The level of shut-in production would probably leave an insufficient supply of light crude oil available to operate both Four Corners Lines 1 and 63. Chevron and the Bakersfield area refineries would probably bid aggressively for this oil. If Four Corners no longer had Elk Hills crude oil to ship 10 Los Angeles, it would probably close Line 1 and heat Line 63.

Four Corners has investigated the possibility of reversing its pipelines to carry Alaskan North Slope (ANS) crude oil from Los Angeles to San Joaquin Valley refineries. It concluded that the market would not be sufficient to justify the expense of reversing the pipelines.

Some cutback in employment at Four Corners would be expected if NPR-1 is shut in because revenues from the pipelines would decrease. However, employment could return to former levels if Line 63 is heated and shipments of heavy oil increase. 


\section{Trucking Companies}

The short-and long-term impacts of a shut-in of NPR-1 on tank lruck companies are not clear becaluse the industry would be subject to conflicting influences. All Elk Hills natural gas liquid production is currently shipped by truck. If Elk Hills were shut in, trucking companies would lose a substantial portion of the natural gas liquids shipping business. However, the loss of Elk Hills crude oil production should increase the demand for other local crude oils, and truckers may be able to move some of this additional heavy oil production. Thus, the effects of shut-in on employment in trucking companies in the short-term are impossible to determine precisely, although it would seem logical that employment would fall.

In the long term, if Four Corners Pipe Line Company heats Line 63, it will be able to transport even more heavy oil than it can currently move. Then, trucking companies should lose any additional heavy oil business they picked up as result of increased local production after NPR-1 shutin, as well as losing the NPR-1 natural gas liquids business.

\section{IMPACTS ON NATIONAL DEFENSE CAPABILITIES}

\section{Impacts on National Defense Petroleum Requirements in a War}

DOD's petroleum requirements in a war involving multiple theaters and full mobilization could increase two or three times from current peacetime requirements of approximately 500,000 BOPD. This higher level of demand could occur very quickly, and difficulties in meeting it may be exacerbated by supply system disruptions. To meet that requirement, DOD has war reserves of military fuels to sustain combat operations until expanded supply channels can be opened. It should be noted that these military fuel reserves are designed for wartime use and are not intended for use in peacetime energy emergencies. 


\section{DOD Impacts During Peacetime Oil Supply Disruptions}

As noted above, DOD's peacetime use of petroleum totals about 500,(0)(0) BOPD, and this demand is expected to increase modestly in the future. When market conditions are expected (1) adversely affect, or have adversely affected, DOD's ability to acquire defense supplics to meet peacetime, surge, mobilization, or wartime requirements, DOD may pursue the following authorities:

- Waiving provisions of law prescribing procedures for forming contracts or regulating the performance of contracts to expedite or lacilitate obtaining petroleum not otherwise available to DOD under 10 U.S.C. $24(14$.

- Requesting the DOE to provide DOD access to any portion of the U.S.'s share of crude oil produced from the NPR with reimbursement at the market price for DOD's use, exchange, or sale under 10 U.S.C. $74.30(1)$

- Recommendirg to the President that DOD be given the right of first refusal to purchase at the market price all or any portion of crude oil produced from the Outer Continental Shelf for its use or for acquisition by exchange under 43 U.S.C. 1341(b);

- Recommending to the Secretary of Energy and/or the President the necessary actions to be taken that will lead to drawdown and distribution of the SPR and/or that crude oil from the SPR to be allocated for use by DOD under 42 U.S.C. 6241 and the SPR Distribution ("drawdown") Plan;

- Requesting DOE to provide Defense Production Act of 1950 (DPA) energy product priority assistance that would permit DOD to obtain petroleum supplies from domestic refiners or other suppliers on a priority basis.

While these emergency measures can be used in the event of war, they are primarily for peacetime energy emergencies. Recent reductions in DOD fuel stocks make these emergency authorities all the more important for defense readiness. 
Maintaining an adequate crude supply to the marketplace by drawdown of the SPR can provide substantial assurance that defense fuel needs are sutisfied. DOD stands to benelit direcaly or indirectly in three ways from an SPR drawdown. First, SPR erude oil will increase the level of supply available to the marketplace, so historical delense suppliers will have more petroleum to refine and be better able to maintain fuel deliveries for defense contracts. Second, the release of SPR oil into the market will facilitate procurement and reduec the costs of defense purchases on the open market. Last, although there are no current plans to do so, the Secretary of Energy could direct up to 10 percent of an SPR drawdown to DOD or its suppliers lor defense purposes. (The Secretary has discretionary authority to direct up to 10 percent ol" an SPR drawdown to various users.)

\section{Continued Production}

Continued production of NPR-1 lor another three years would provide a secure source of supply equivalent to about 13 percent of DOD's peacetime needs in an oil supply disruption. A Petroleum Transfer Agreement was established between DOE and DOD and used from 1981 through 1986 so that NPR-1 production could be exchanged for relined products to help DOD meet its needs. This reduced DOD's need to purchase oil on the open market or to consider requesting DPA priority assistance to obtain required oil supplies. This agreement is still in effect today; however, it has not been utilized since 1986. To assure supplies for DOD, all contracts for the sale of NPR-1 crude oil include a 10-day cancellation clause in order to make such oil available to the DOD in an emergency.

\section{Shut-In}

A primary weakness of shut-in NPRs for use in short-term disruptions of oil supplies is the relatively long time required to resume full production. It is estimated that six months to a year or more will be required to bring a shut-in NPR-1 back to production at the maximum efficient rate, and it may require as much as one year. In that period, it is likely that DOD will have resolved its supply problems by other means before NPR-1 could provide significant production. Even if NPR-1 could be brought back to full production more rapidly, DOD would still need to acquire over 85 percent of its petroleum requirements from other sources during a peacetime oil supply disruption. 
While DOD's fuel noeds significantly exceed NPR-1 production, NPR-1 still plays an important role in DOD's oil acquisition strategy. Shutting in NPR. 1 would make NPR.1 production unavailable in the early stages of an energy emergency and could seriously harm DOD's liuel situalion during a pencetime energy emergency. 


\section{CONCLUSIONS}

It is the conclusion of this report that it is in the mational interest to emontinue production of the Naval Petroleum Reserves for another three years through April 5, 1994. This conclusion is based on a number of study findings resulting from the comparison of' a shut-in secnario and a range of eontinued production rutes. These lindings have been presented in detail throughout this report. In summary, the most important findlings that have led to the conclusion that the NPRs should continue to be produced are:

- Net present value analysis shows the coconomic value of Elk Hills is higher under continued production than from shut-in.

- Continuing production at the maximum eflicient rate for another three years will provide significant revenues for the Federal Giovernment during the period 1991-1.994.

- Production of the NPRs is not large enough to be an important lactor in mecting defense or other needs in the event of an energy emergency. In the event of shut-in, production could not be started quickly enough to mitigate the short-term effects of an emergency.

- Continued production means less U.S. oil imports are needed.

- Continued production avoids substantial adverse impacts on the California oil and gas industry, including refiners, pipelines, producers, and end users.

- Shutting in NPR-1 would create signiticant unemployment in Kern County, California.

- So many environmental and other permits are required to operate NPR-1 that it would be uneconomical to let them lapse, even if the field were shut in. Consequently, it would be necessary to retain a work force to keep permits current, even during shut-in.

- Shutting in NPR-3 would deprive the Rocky Mountain area of a small but needed amount of oil and the Federal Government of small but useful revenues. It is likely that NPR-3 could not be shut in and 
restarted again coonomically, so the (iovernment's best interest is served by operating the liedel as long as it is ceomential to do so.

- The potential production rates at NPR.3 are so small that there woukl be virtually no national defense value or other national benelit in consorving NPR -3 for luture usc.

- Enhanced oil recovery (EOR) technicpues underway at NPR-3 have the potential to increase the ultimate recovery from this Reserve. Shutting in the Reserves would elfectively negate the EOR ellorts at the site. Continued production will permit continualion of the long. term EOR efforts, which could substantially increase ultimate total recovery.

- Continued production will avoid adverse impace on the people and industry of Casper, Wyoming. Shut-in would result in the loss of several hundred jobs in an economically-depressed area. This could have an impact on the responsiveness of the local economy to a luture energy emergency, as some service firms could leave the area it NPR3 were shut in. 
APPLNDIX I

LIST OF RESPONDENTS

'TO DOE REQUEST' FOR COMMEN'TS 


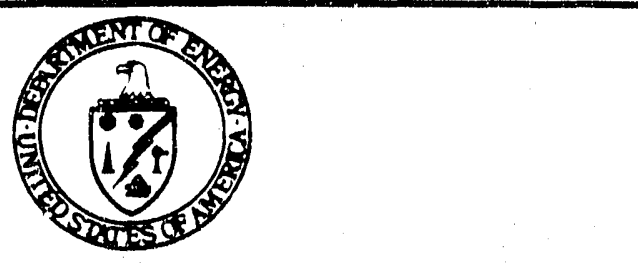

\author{
Department of Energy \\ Washington, DC 20585
}

\title{
To: Interested Parties
}

\section{MAY 251990}

Under the Naval Petroleum Reserve= Production Act of 1976 (Public Law 94-258), the President must maxe a formal determination every 3 years that continued production of the Naval Petroleum Reserves, including NPR-1 (Elk Hills, California) and NPR-3 (Teapot Dome, Wyoming), is in the national interest. Then, after the President submits a report to Congress certifying that continued production of the NPRs is in the national interest, production of the Reserves may continue for up to 3 years.

The authority provided by the last Presidential determination runs out in April 1991. A copy of the last Presidential report is enclosed for your convenience. The Office of Petroleum Reserves is currently drafting the report to Congress on whether extending NPR production past April 1991 is in the national interest.

The most recent reauthorization study, which governed production for the 3 years after April 5, 1988, concluded that it was in the national interest to continue production of the NPRs based on the following benefits: a) obtaining Federal revenues, b) avoiding an increase in oil import costs, and c) avoiding the local and regional impacts of shutting in production. Among the local and regional impacts of shut-in for Southern California were the loss of employment, a lack of suitable replacement crudes, higher refinery costs associated with heavier replacement crude oil, and the disruption in operations of crude oil pipelines and refineries.

Preliminary analysis indicates that the benefits associated with continued production of the Naval Petroleum Reserves remain unchanged; however, the Department is interested in your views on the subject of continuing NPR production. If you are interested, please submit your comments for receipt by June 15, 1990, to: NPR Reauthorization Corments; Analys is Division; Office of Planning and Financial Management; Office of Petroleum Reserves; FE-431, Room 3G045; U.S. Department of Energy; Washington, D.C. 20585. Any questions may be directed to Jerry Hinkle at (202) 586-4380.

Thank you for your cooperation.

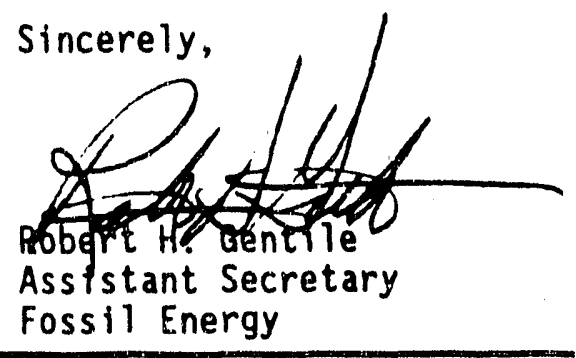




\section{RESPONDENTS}

Alton Corporation

Bravo Energy Trading N.A.

Chevron U.S.A. Incorporated

Crysen Corporation

Four Corners Pipe Line Company

Golden West Refining Company

Kern Oil and Refining Company

Southern California Gas Company 
APPENDIX II

BASELINE PRODUCTION CASES 


\section{BASELINE PRODUCTION CASES}

$\begin{array}{lc} & \text { Page } \\ \text { Intermediate Production Case - OMB Price Path } & \text { II-3 } \\ \text { Shut-In Case - OMB Price Path } & \text { II-4 } \\ \text { Intermediate Production Case - AEO Base Price Path } & \text { II-5 } \\ \text { Shut-In Case - AEO Base Price Path } & \text { II-6 } \\ \text { Intermediate Production Case - DOE Share - OMB Price Path } & \text { II-7 } \\ \text { Shut-In Case - DOE Share - OMB Price Path } & \text { II-8 } \\ & \\ \text { Intermediate Production Case - DOE Share - AEO Base Price Path } & \text { II-9 } \\ \text { Shut-In Case - DOE Share - AEO Bạse Price Path } & \text { II-10 }\end{array}$




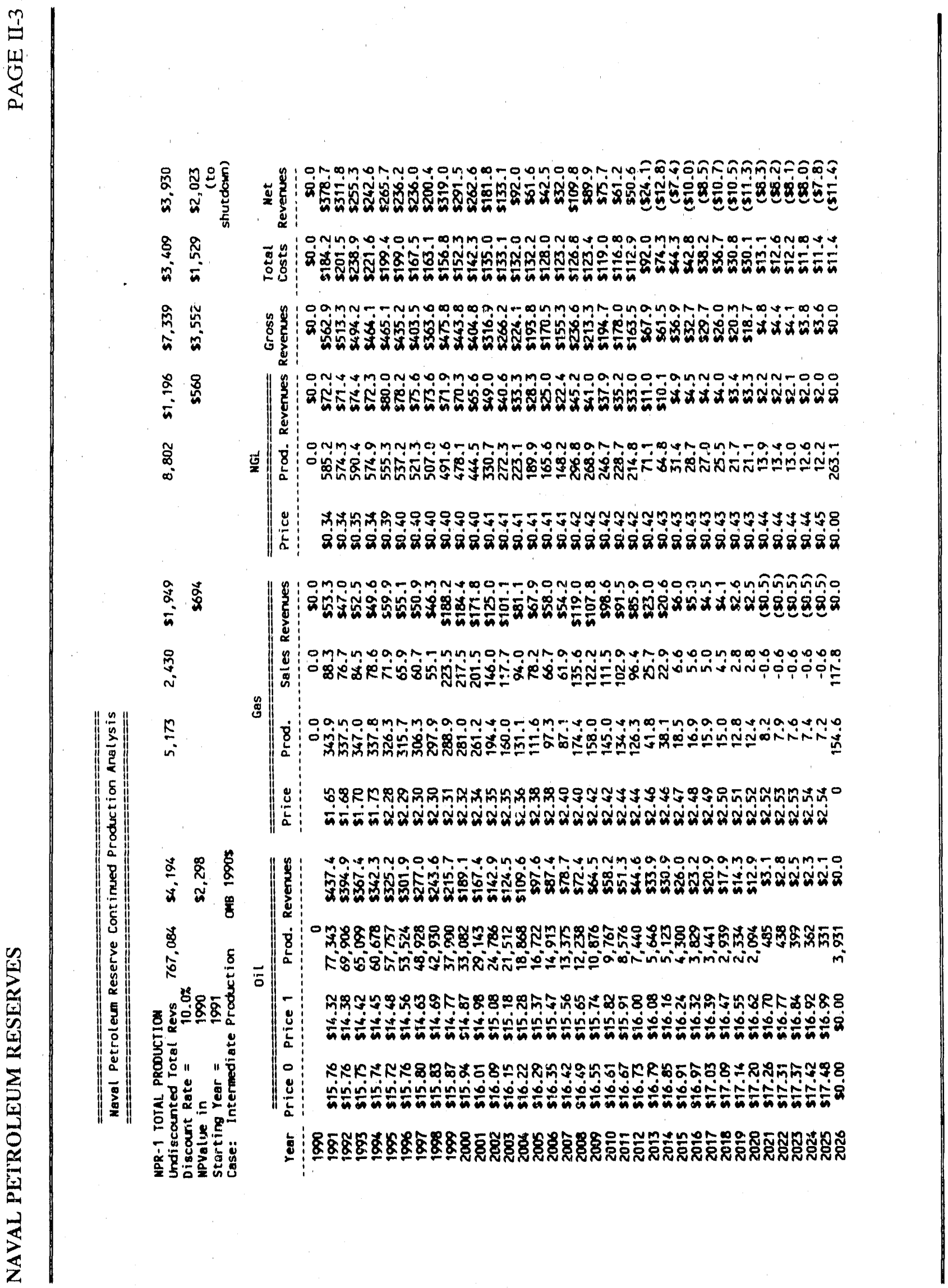




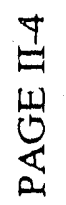

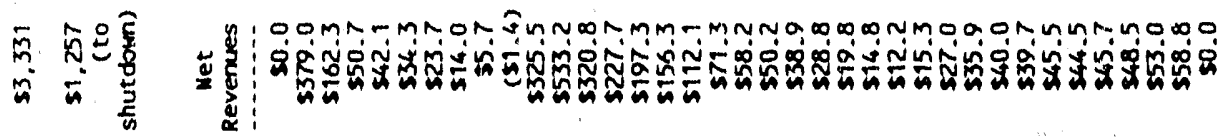

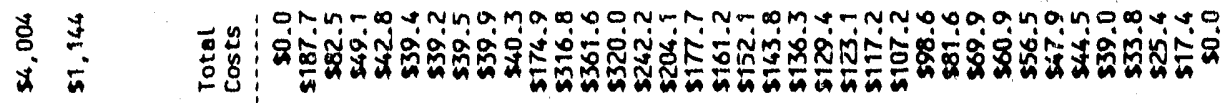

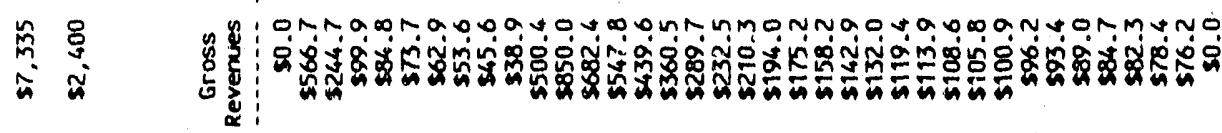

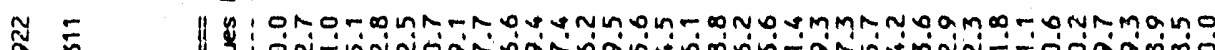
施

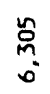

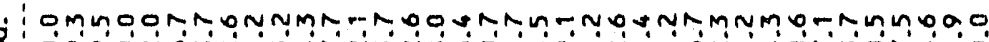

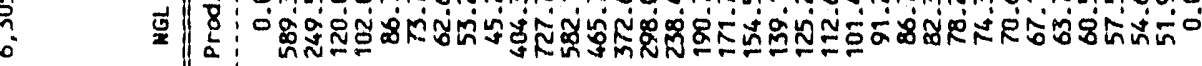

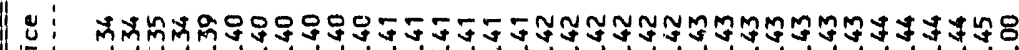

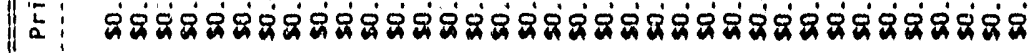

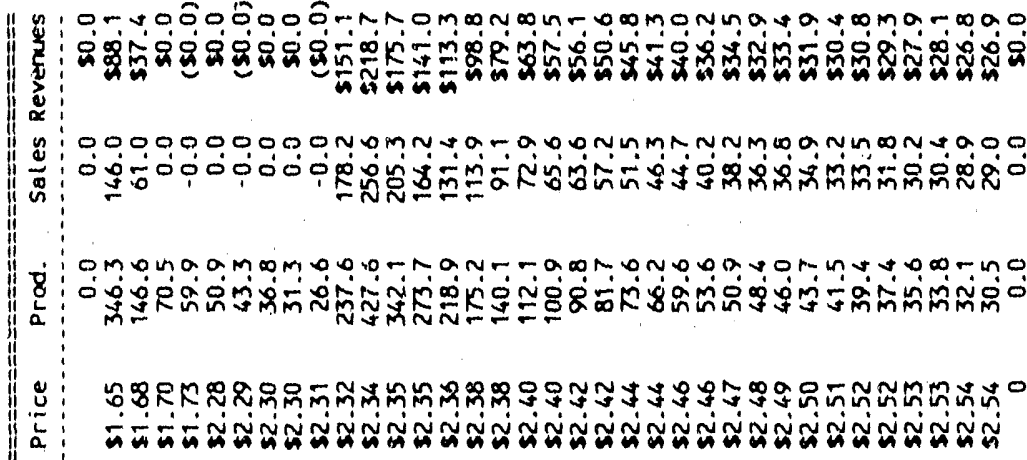

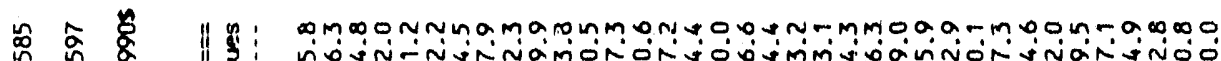

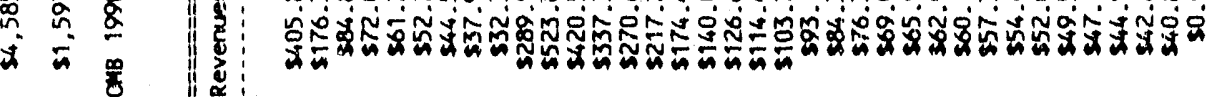
赵 ó

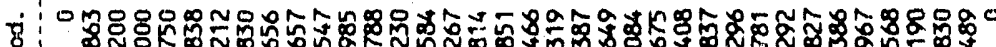

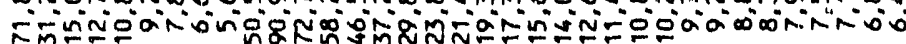

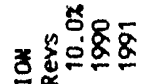
可

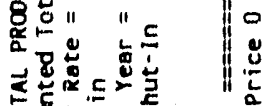

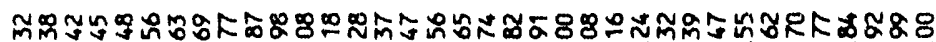

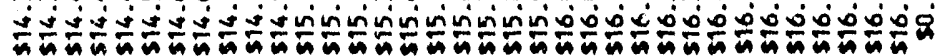

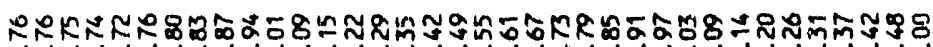
क्ष

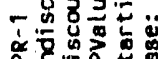

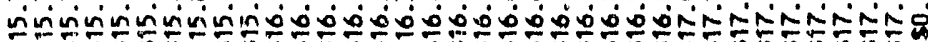

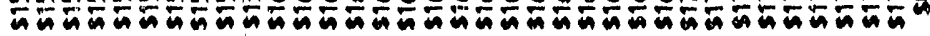
率 


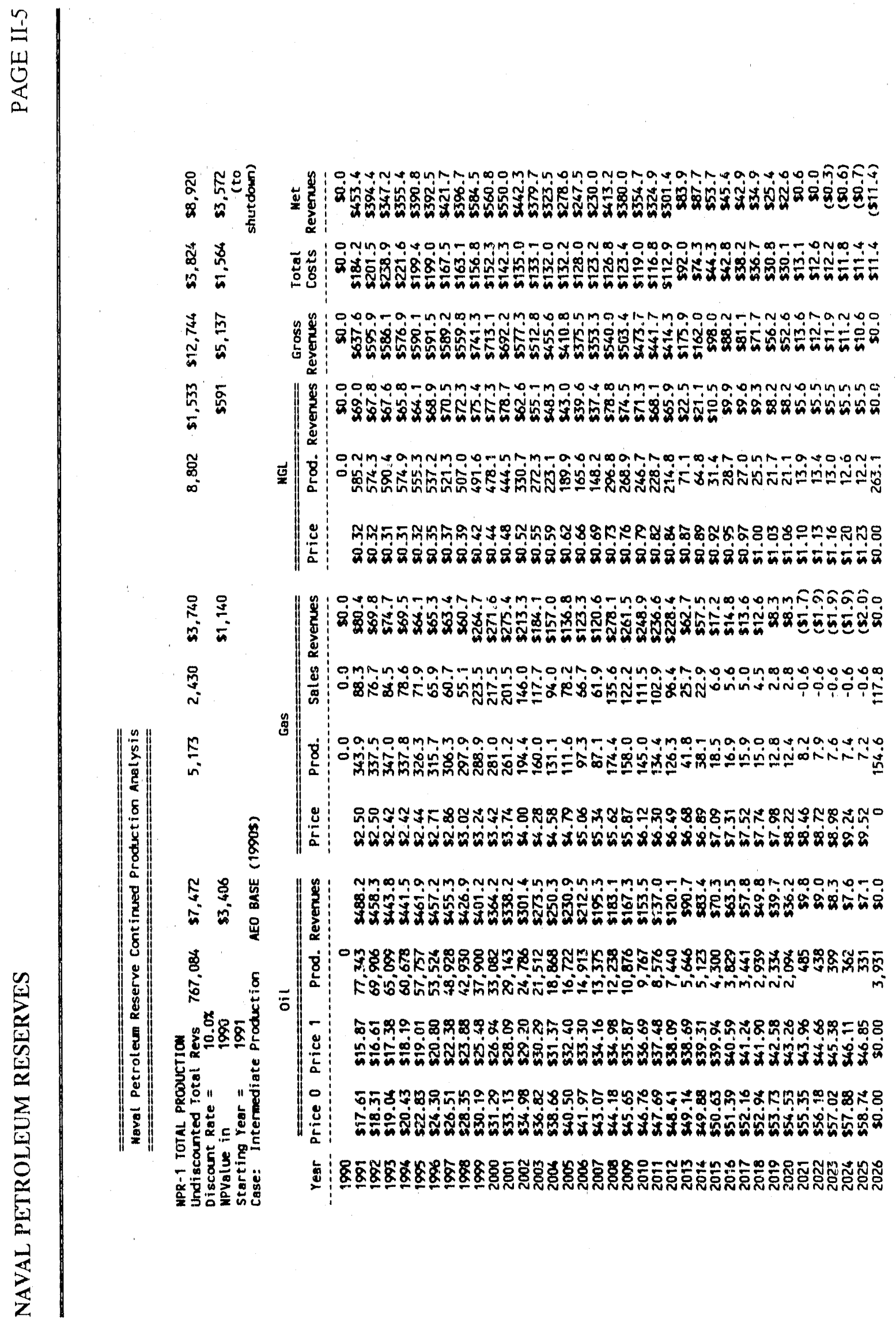




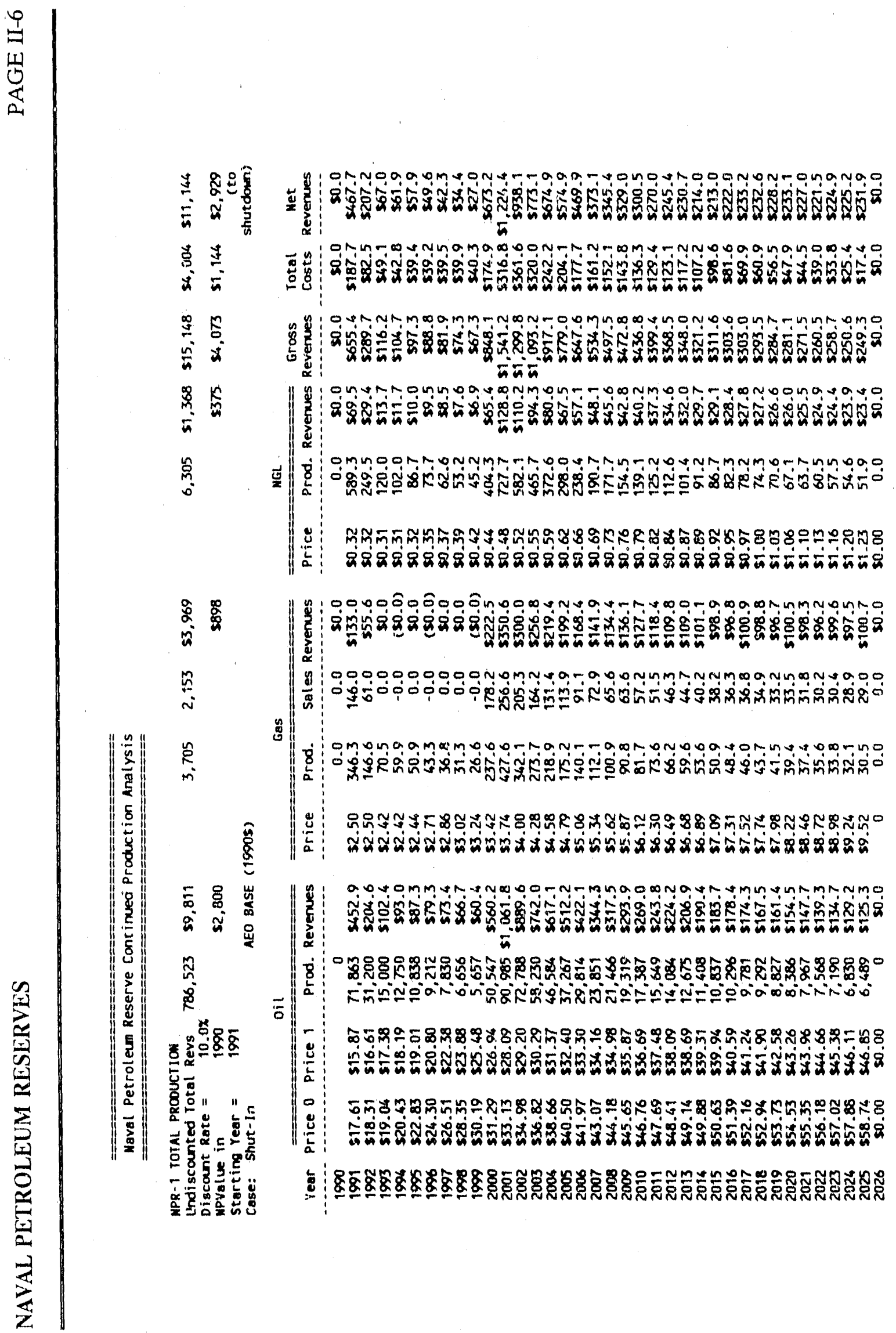




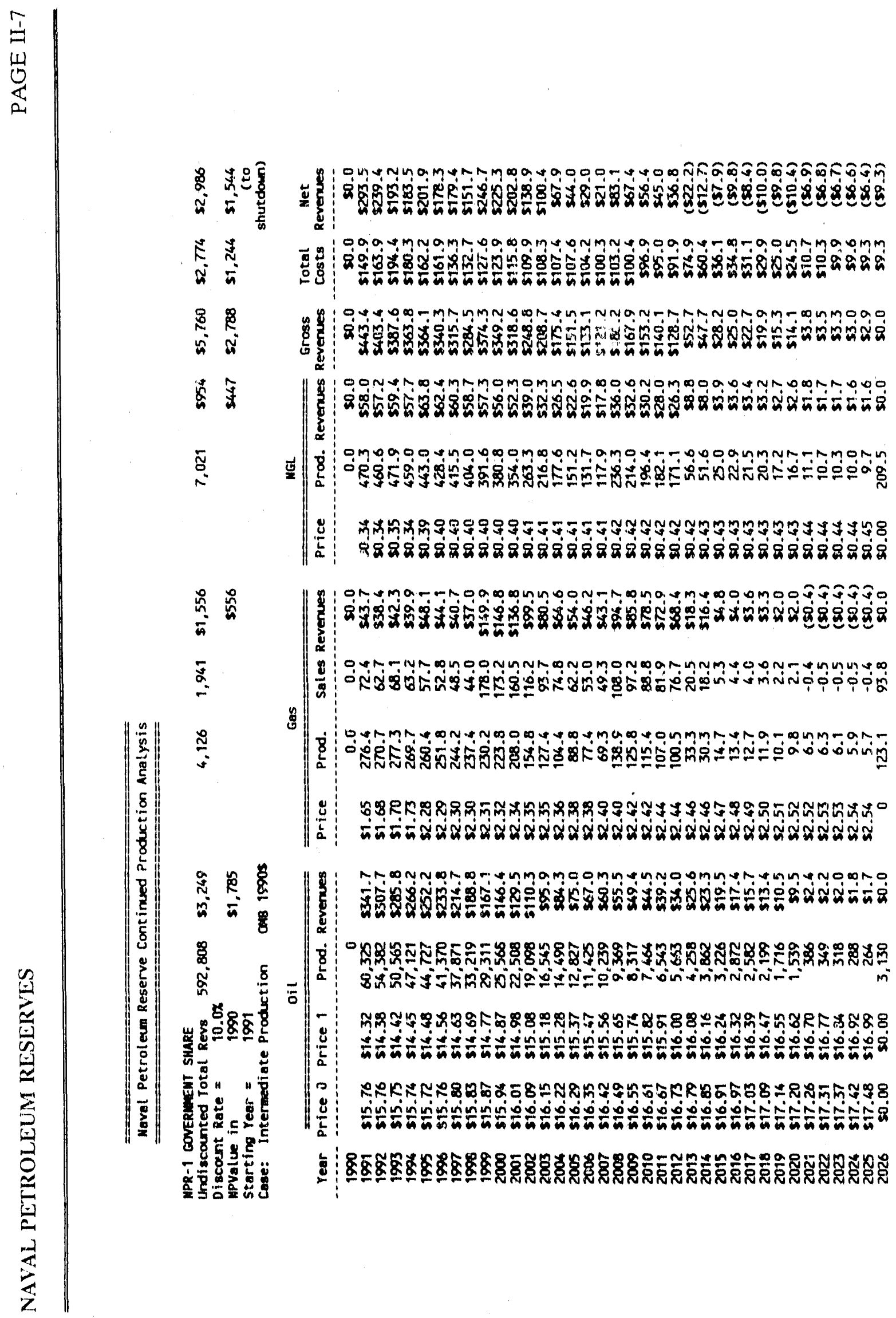


$\stackrel{\infty}{=}$

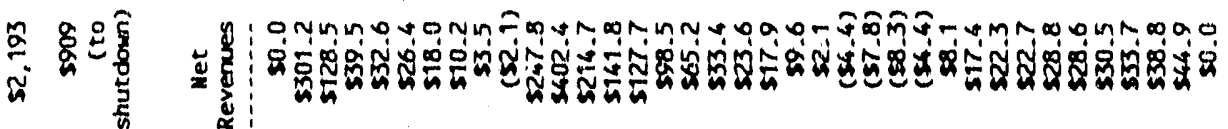

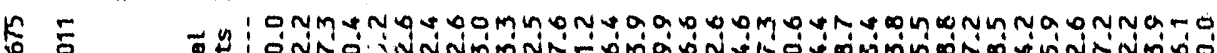

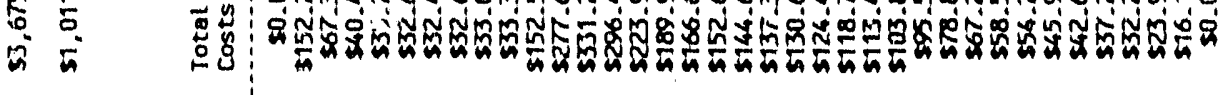

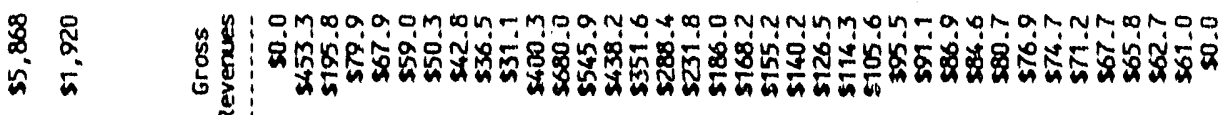
菖 总 亦

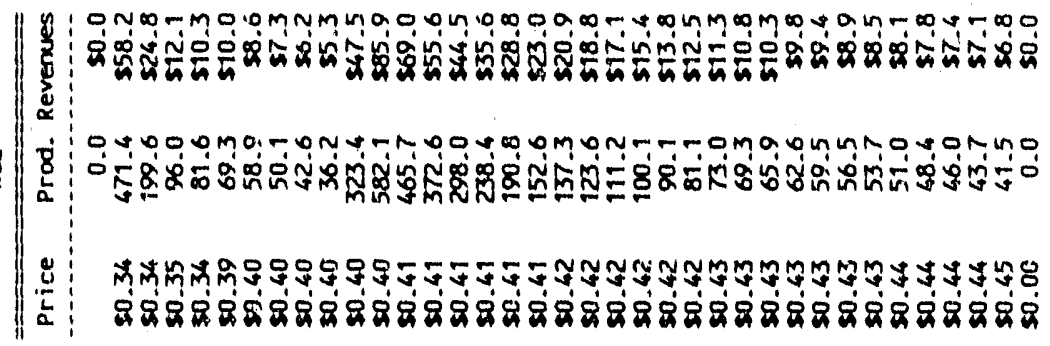

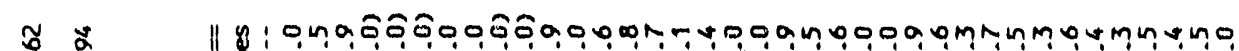
T. \% $\stackrel{2}{5}$

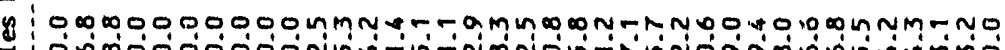
के

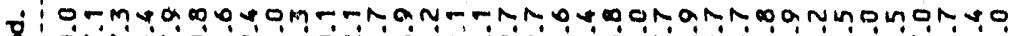
8

\&

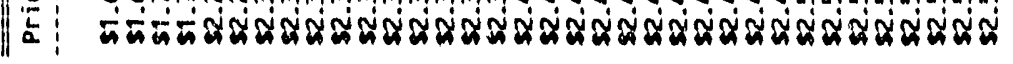

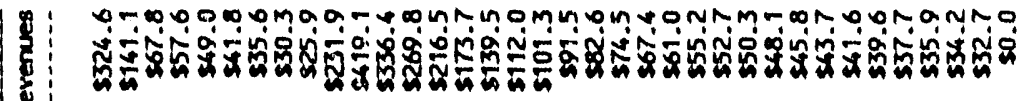

$\stackrel{\infty}{\sim}$

:

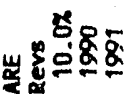

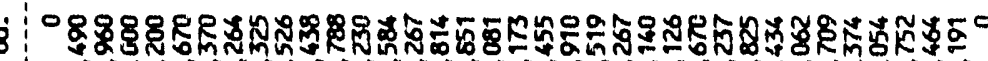

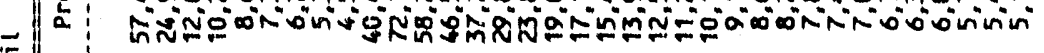
논要" $"$

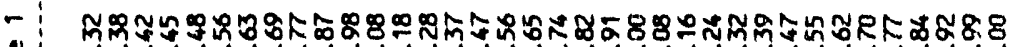

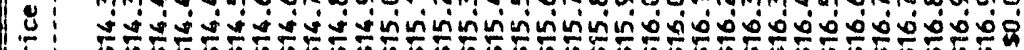

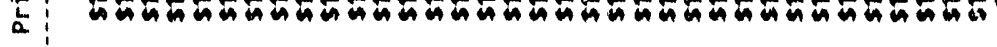

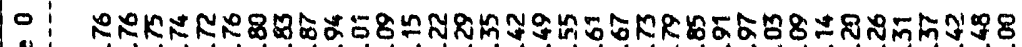

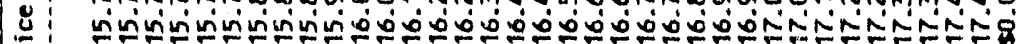

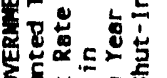

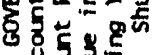

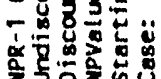

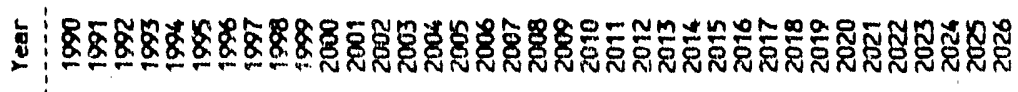




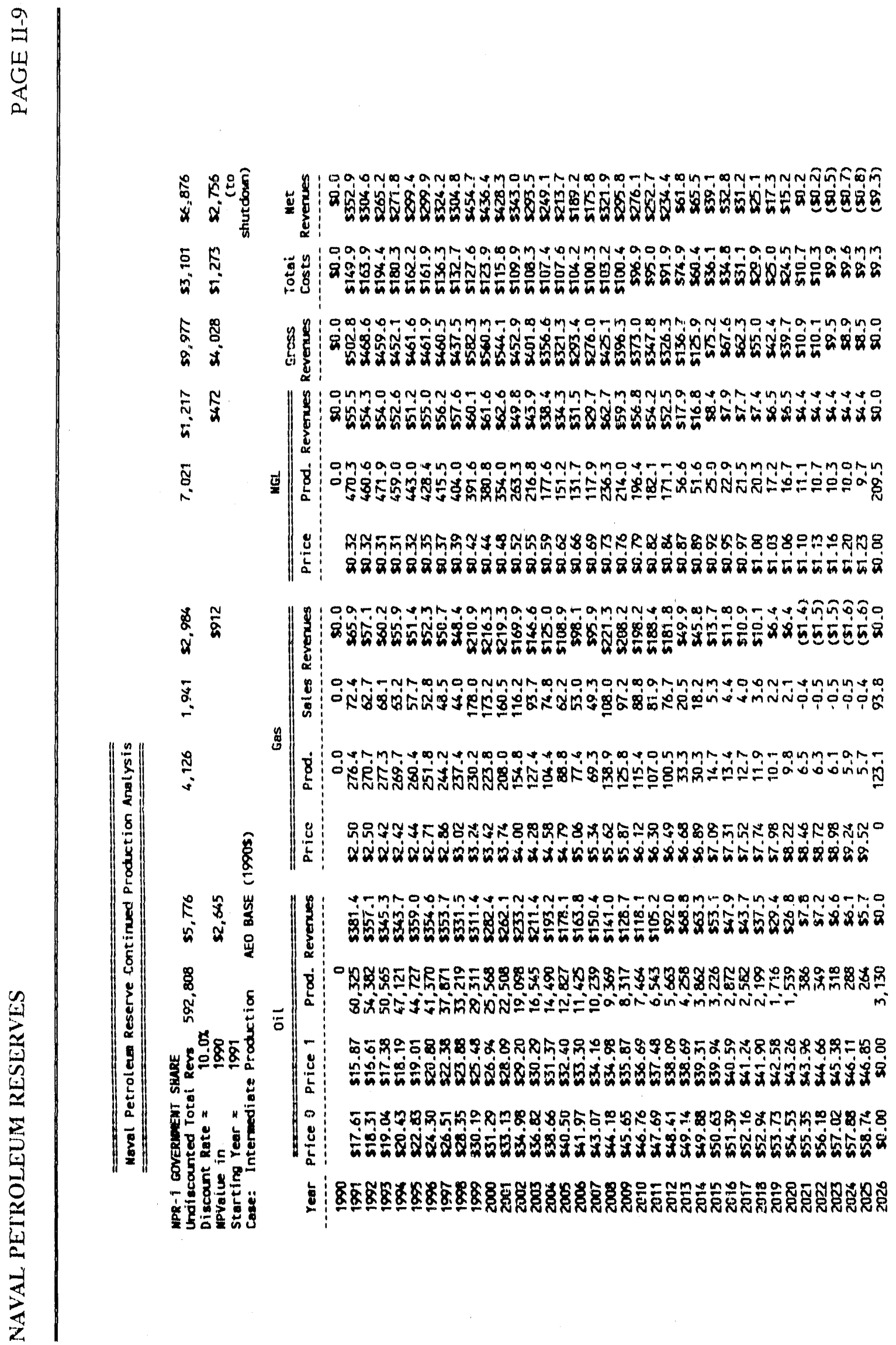




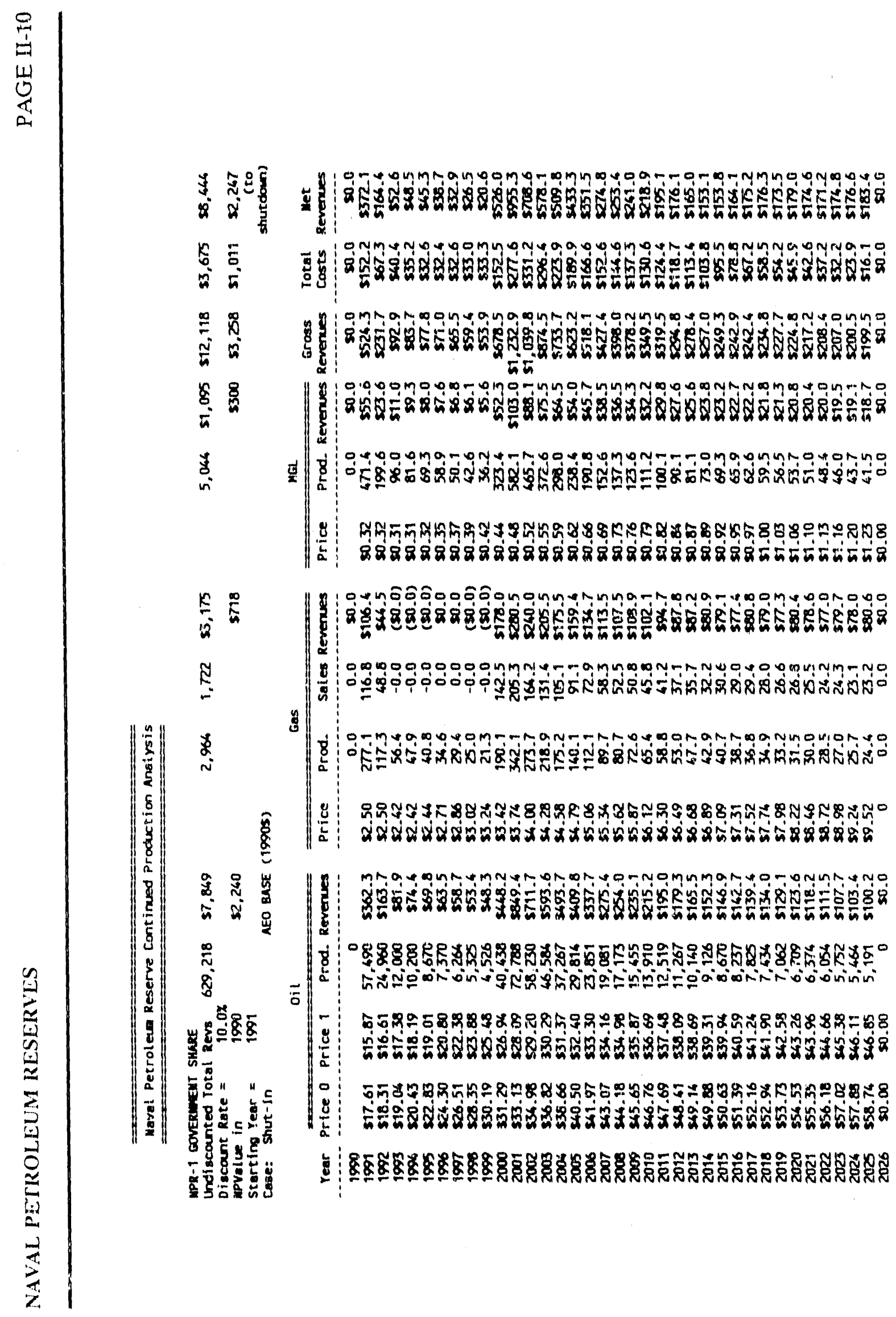




\section{APPENDIX III}

MANAGEMENT' OF' SHU'T-IN RESERV(OIRS 


\section{NPR-1 SHUT-IN CASE: Operational strategy from reservoir standpoint}

The current overall strallegy lor shut-in al NPR-1 is:

- Imrnediately shut in all wells with low waler cut $(<10 \%$ water, $>90 \%$ (oil).

- Reduce production rate of high walter cut wells.

- Maintain reservoir pressures through gas injections.

- Develop remedial program for cach reservoir on an inclividual basis.

Four reservoirs will continue to be prostued at current rates:

- $2 \mathrm{~B}$ - this small reservoir is nearing depletion, and will be lelt in procluction to recover the most reserves.

- Asphalto - similar situation to 2B; identical procedure.

- Dry Gas Zone - gas production will continue al present rate to provide injection gas 10 maintain reservoir pressure in Stevens Zone.

- Carneros - gas production also needed for Stevens Zone pressure maintenance.

Stralegy for the remaining reservoirs is as follows:

- MBB/31S - this largest and most complicated of the Stevens reservoirs will require coordination of a number of activities to shut-in effectively and without detriment to reserves: Shut in low walter cut wells, reduce rates in high water cut wells, and reduce water injection. Gils injection will be resumed along crest of structure. A remedial program to lest wells and plug off wet strata will be doveloped.

- 26R/N\&A Shales - shut in low water cul wells, reduce rates in high water cut wells, and continue gas injection.

- $\quad 24 Z$ Sand - shut in low water cut wells, reduce rates in high water cut wells, reduce water injection, and initiate gas injection at crest of structure.

- NWS - the A1-A.3 sands would be shut in using the same procedure as the $26 \mathrm{R} / \mathrm{NA}$ Shales, by shutting in low cut wells, reclucing high cut wells, and continuing gas injection. The A4-A6 sands, currently being waterflooded, require simple reduction of production rates and water injection rates. A remedial program to plug wet producing zones is also necessary. 
- $\quad 31 S$ C\&D Shales - shut in low water cut and high GOR wells, initiate gas injection to enhance reservoir pressures, and develop remedial programs to plug wet zones.

- 29R/24Z Shales - same as 31S CD Shales.

- NWS T\&N Shales - same as .3IS and 29R. 
APPENDIX IV

SENSITIVITY CASES 


\section{SENSITIVITY CASES}

Page

Intermediate Production Case - AEO High Price Path IV -3

Shut-In Case - AEO High Price Path IV -4

Intermediate Production Case - AEO Low Price Path IV -5

Shut-In Case - AEO Low Price Path IV -6
a

Intermediate Production Case - AEO Disrupted Base Price Path IV-7

Shut-In Case - AEO Disrupted Base Price Path IV-8

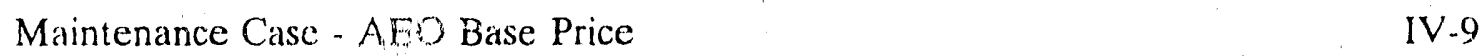

Total Development Cise - AEO Base Price IV-10 


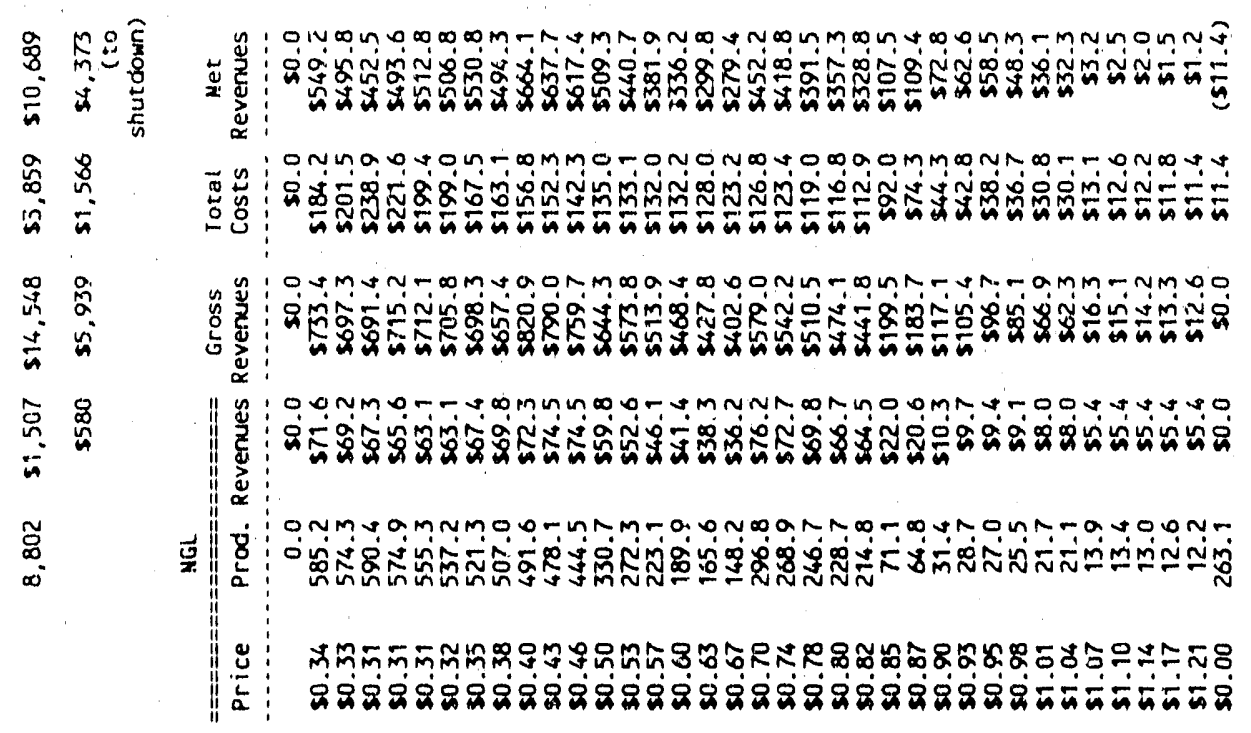

$\stackrel{\infty}{\circ} \stackrel{\infty}{\circ}$

in

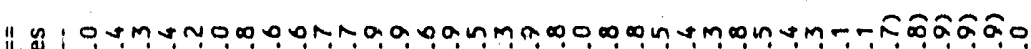
10

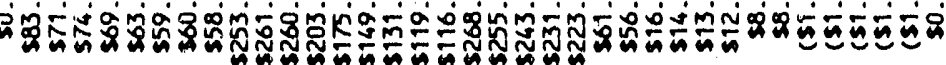

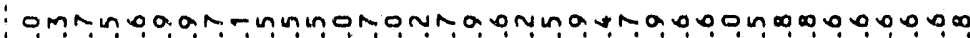

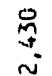

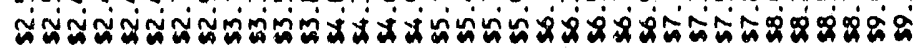

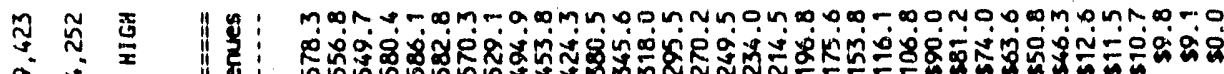
in $x$ 递

字

ช

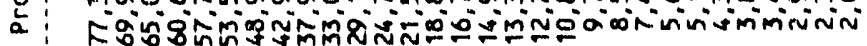

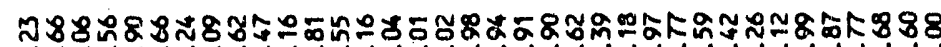

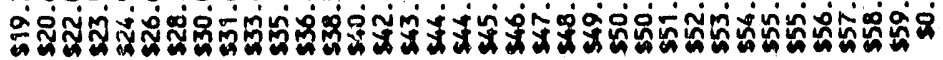

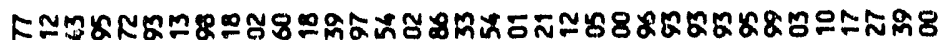

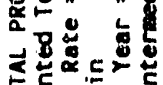

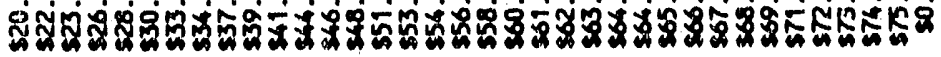
: 
$\underbrace{+}_{\substack{1 \\ \hline}}$

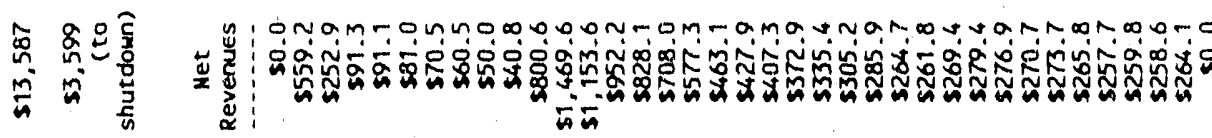

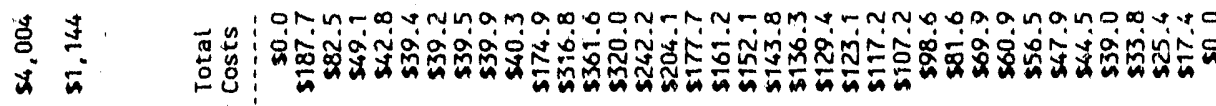

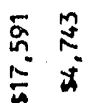

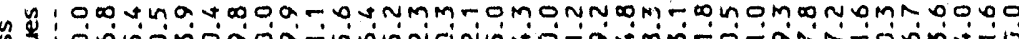

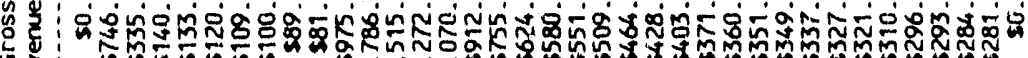
\&

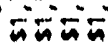

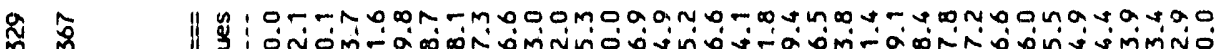

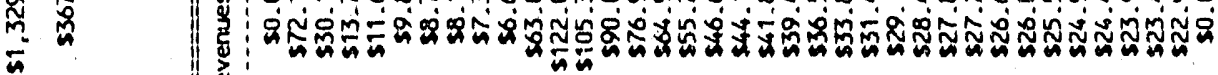
a

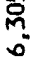

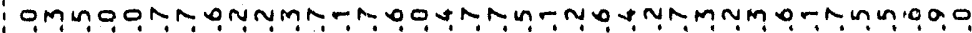

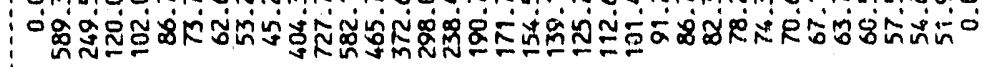

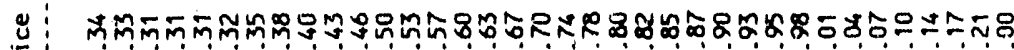

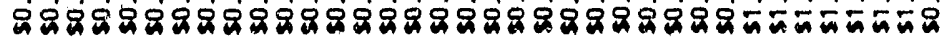

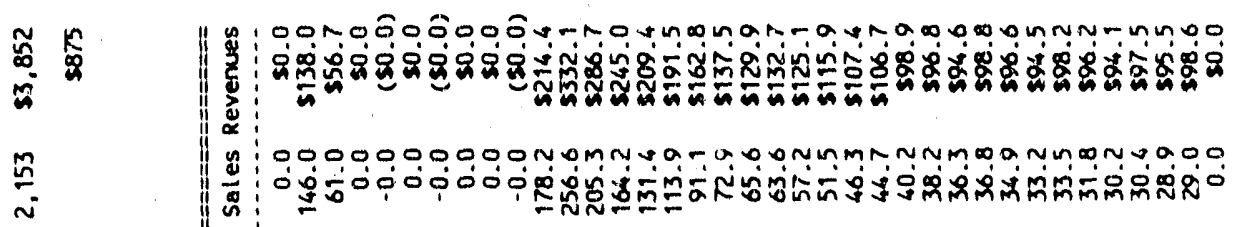

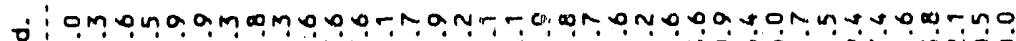

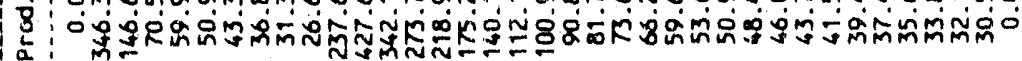

$\stackrel{\substack{2 \\ m}}{m}$

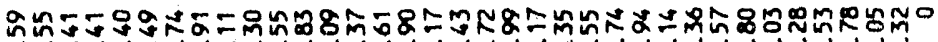

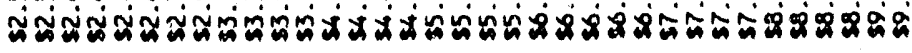

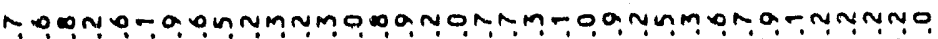

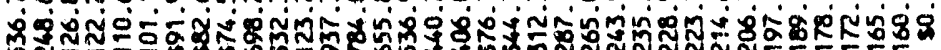

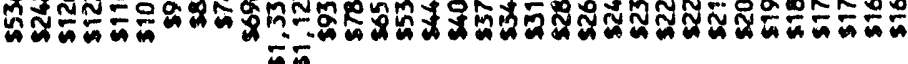

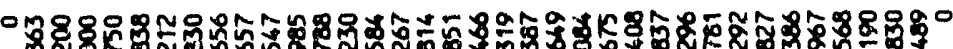

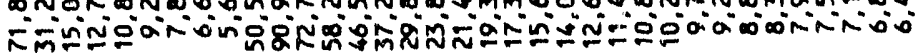

कृ.

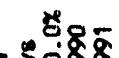

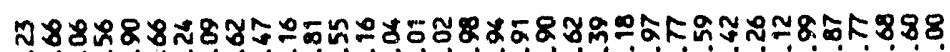

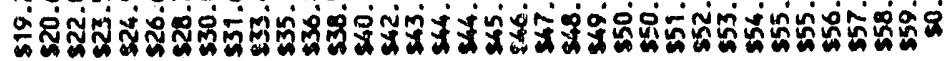
물 象" "

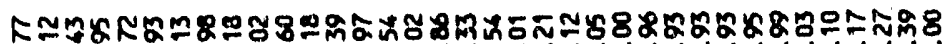
ชิ่ง 


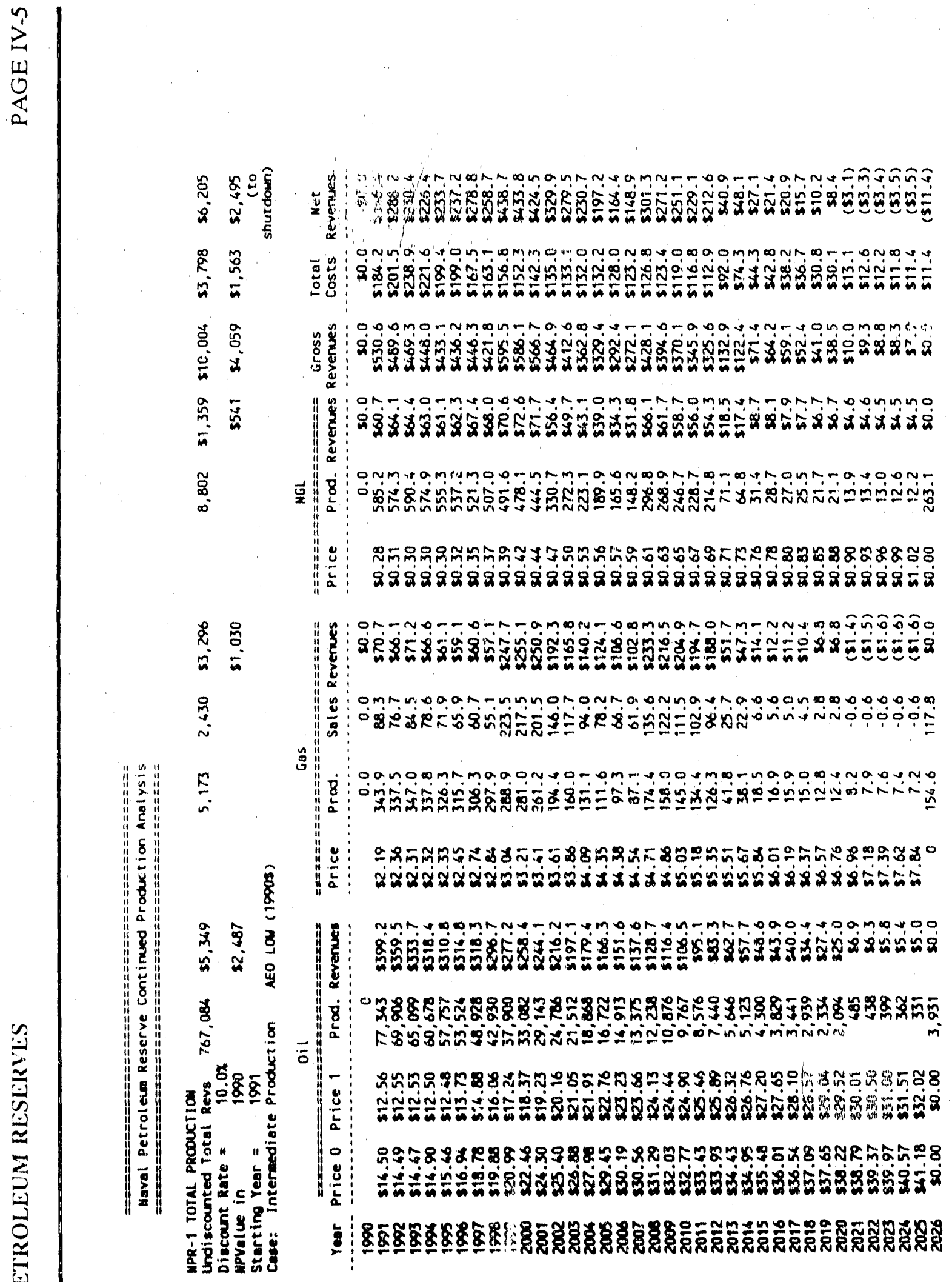




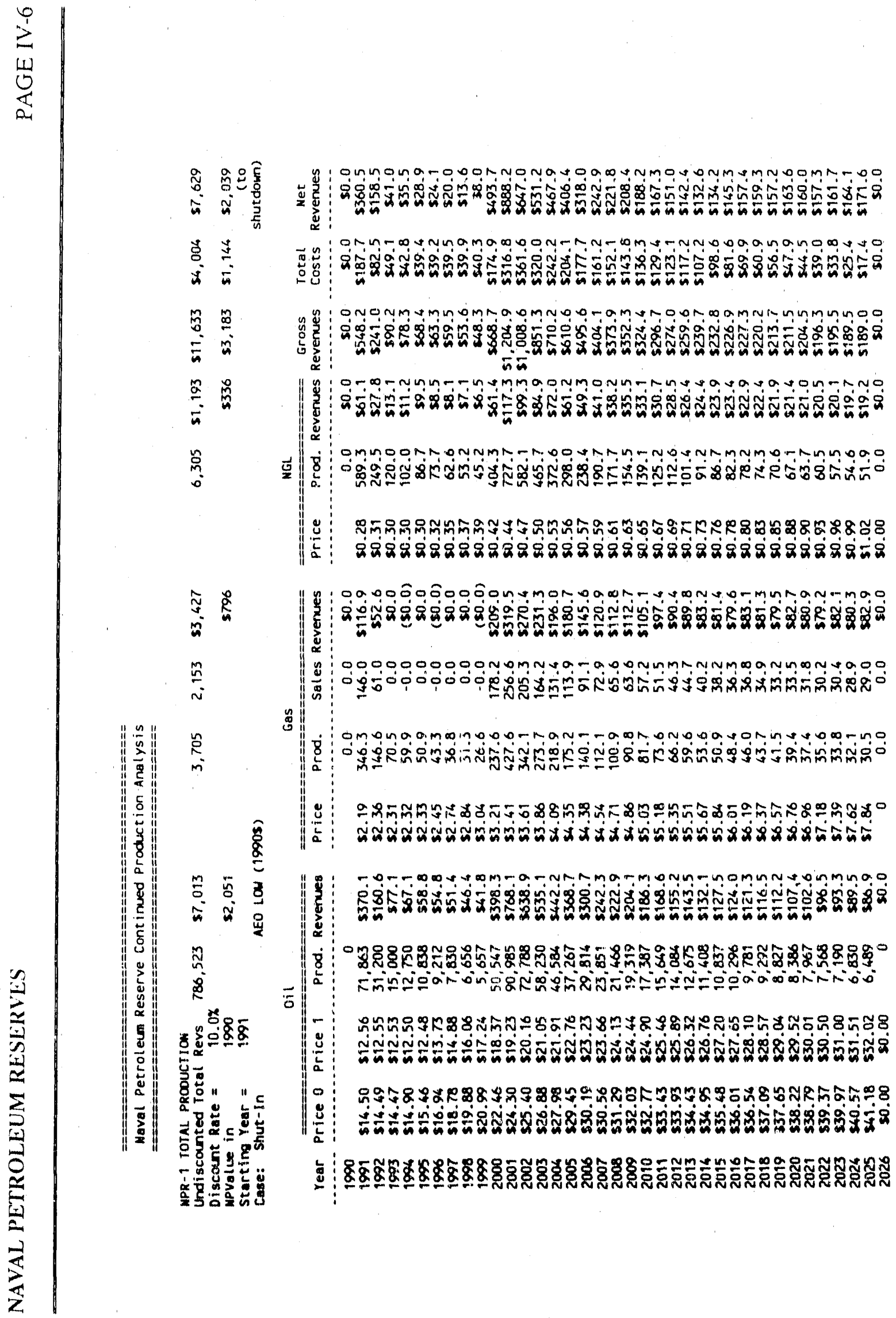




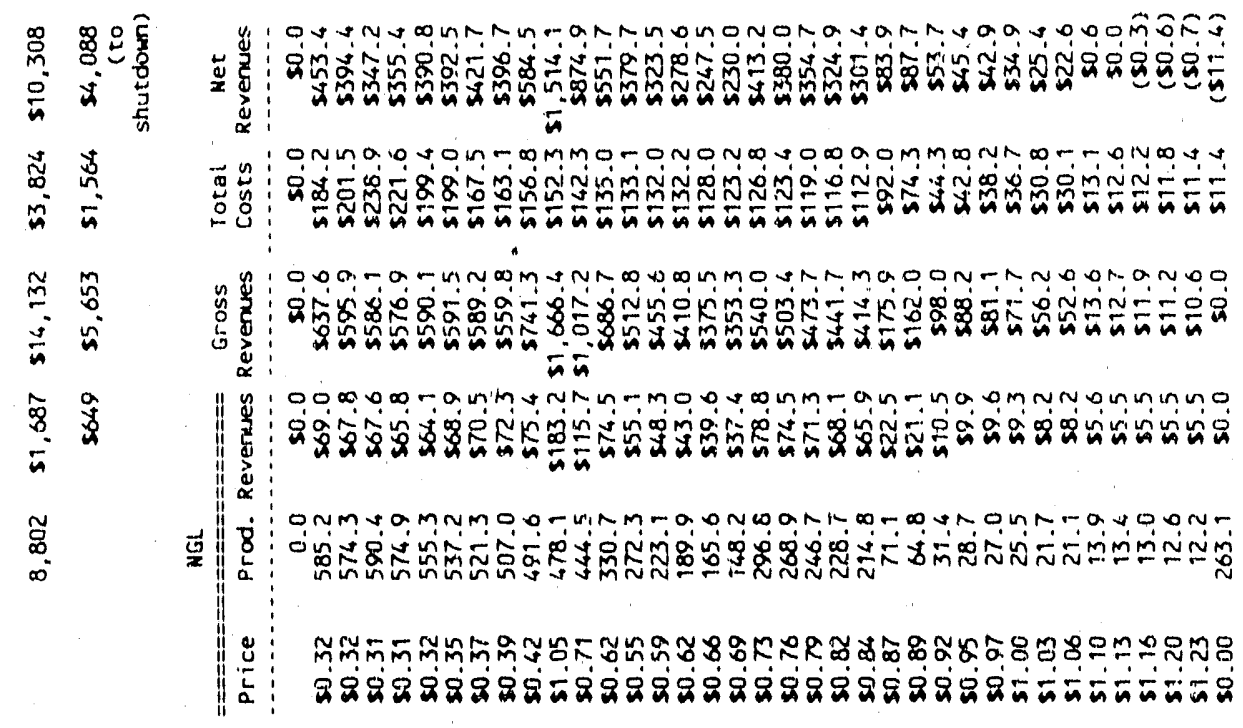

$\stackrel{\bar{s}}{\bar{s}}$ मे

兽. i

号

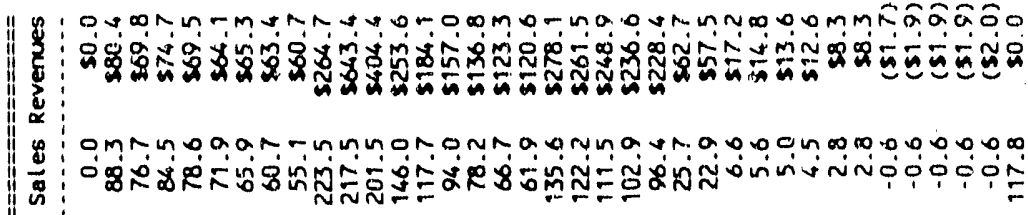

$\stackrel{k}{\frac{k}{n}}$

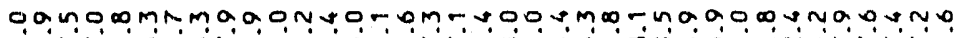

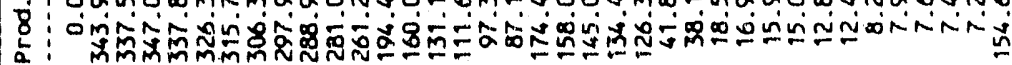

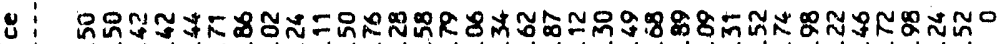

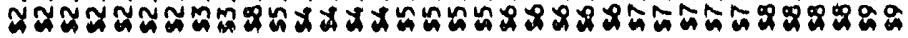

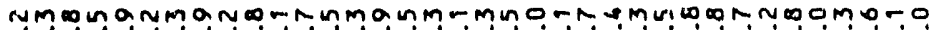

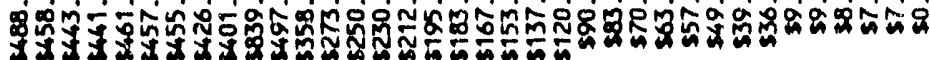

s. i.

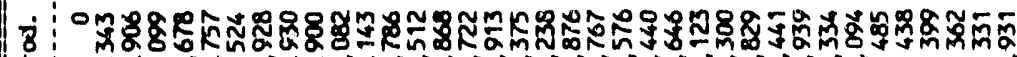
宁

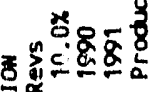

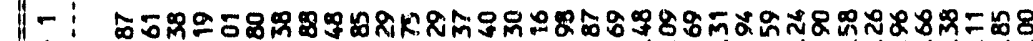

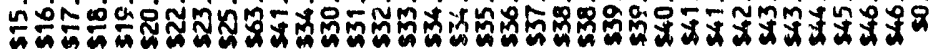
క气ّ

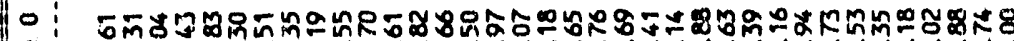

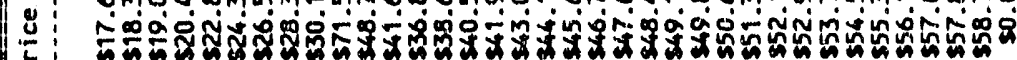

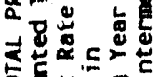

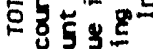

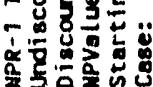

\section{每}




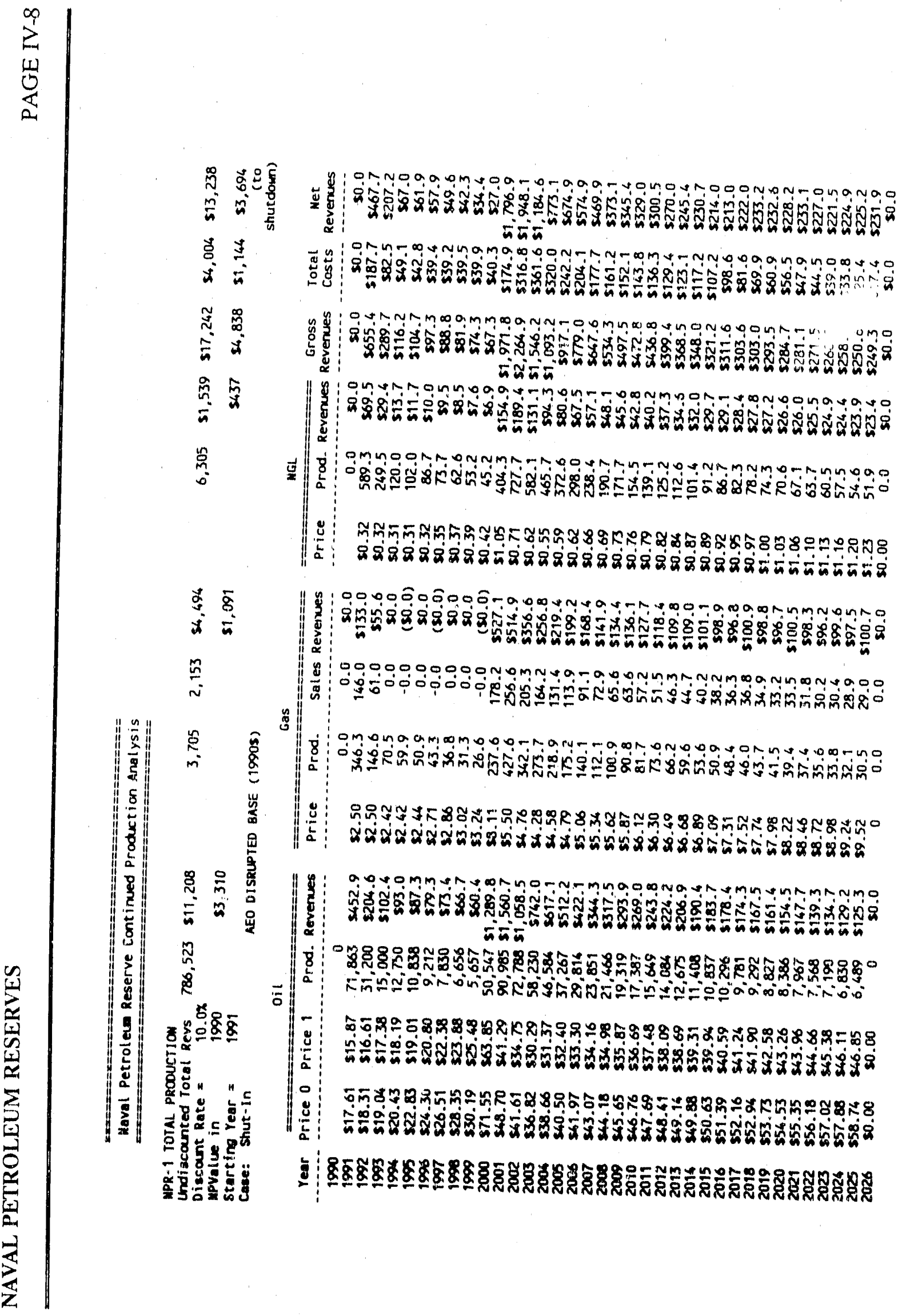




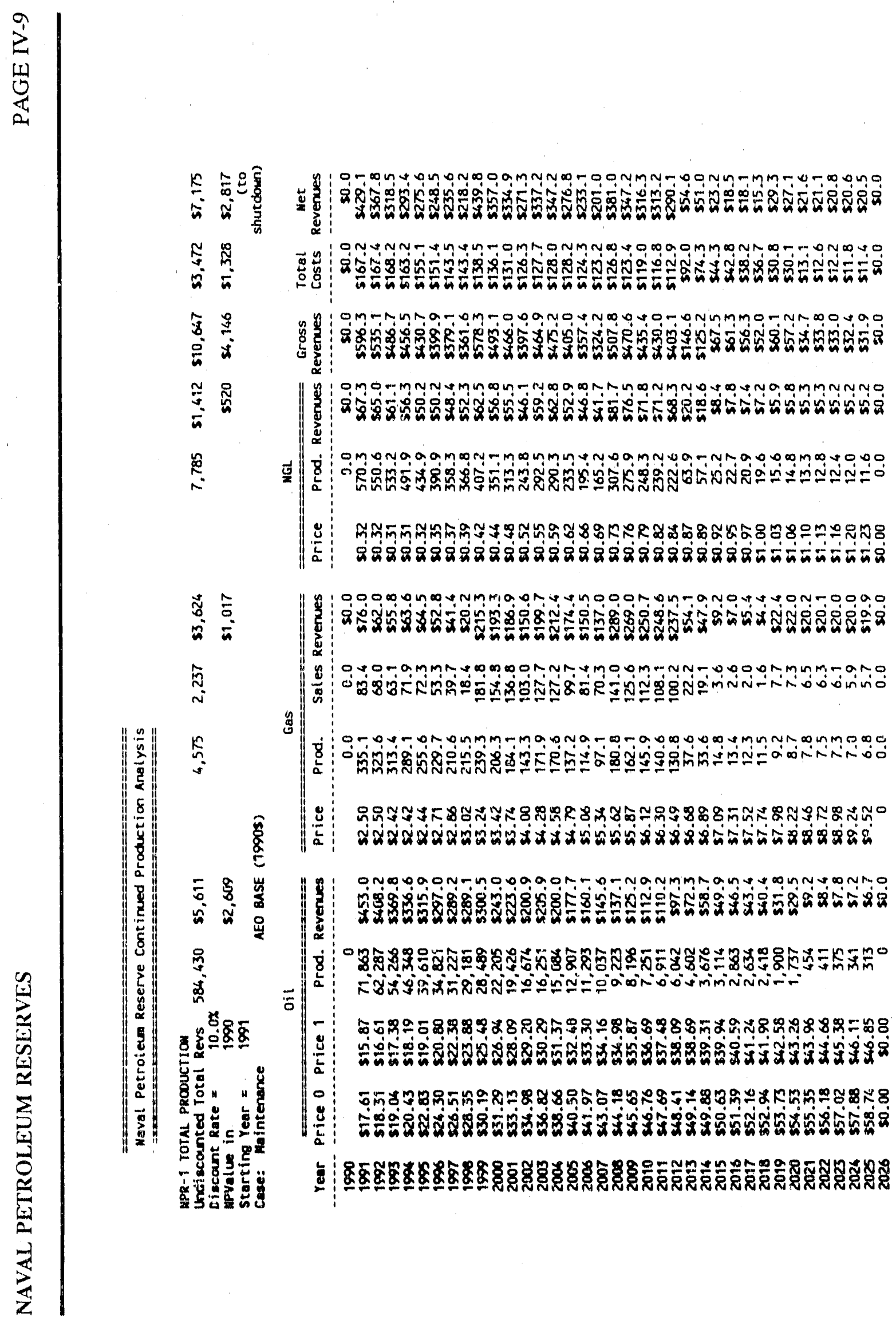




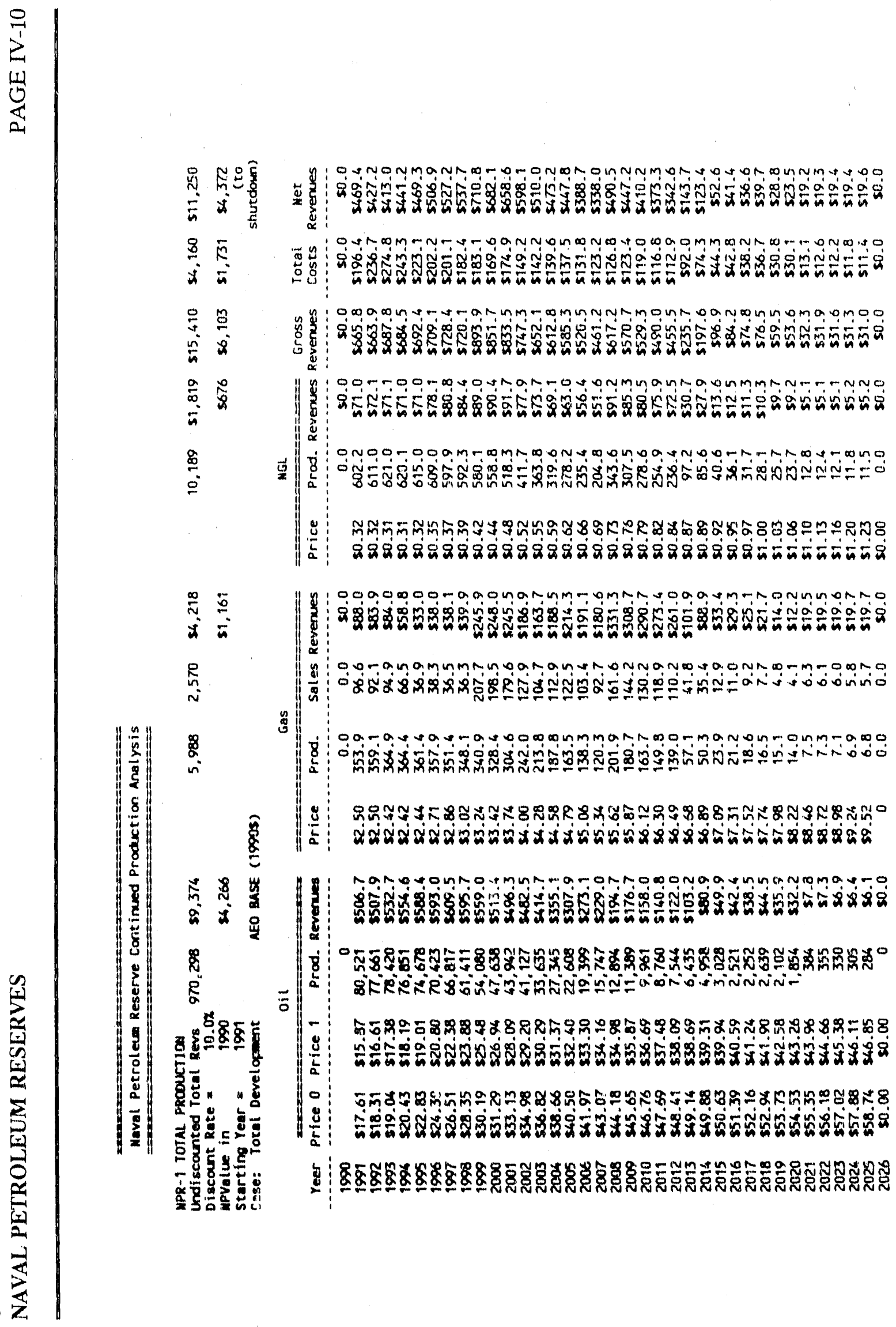



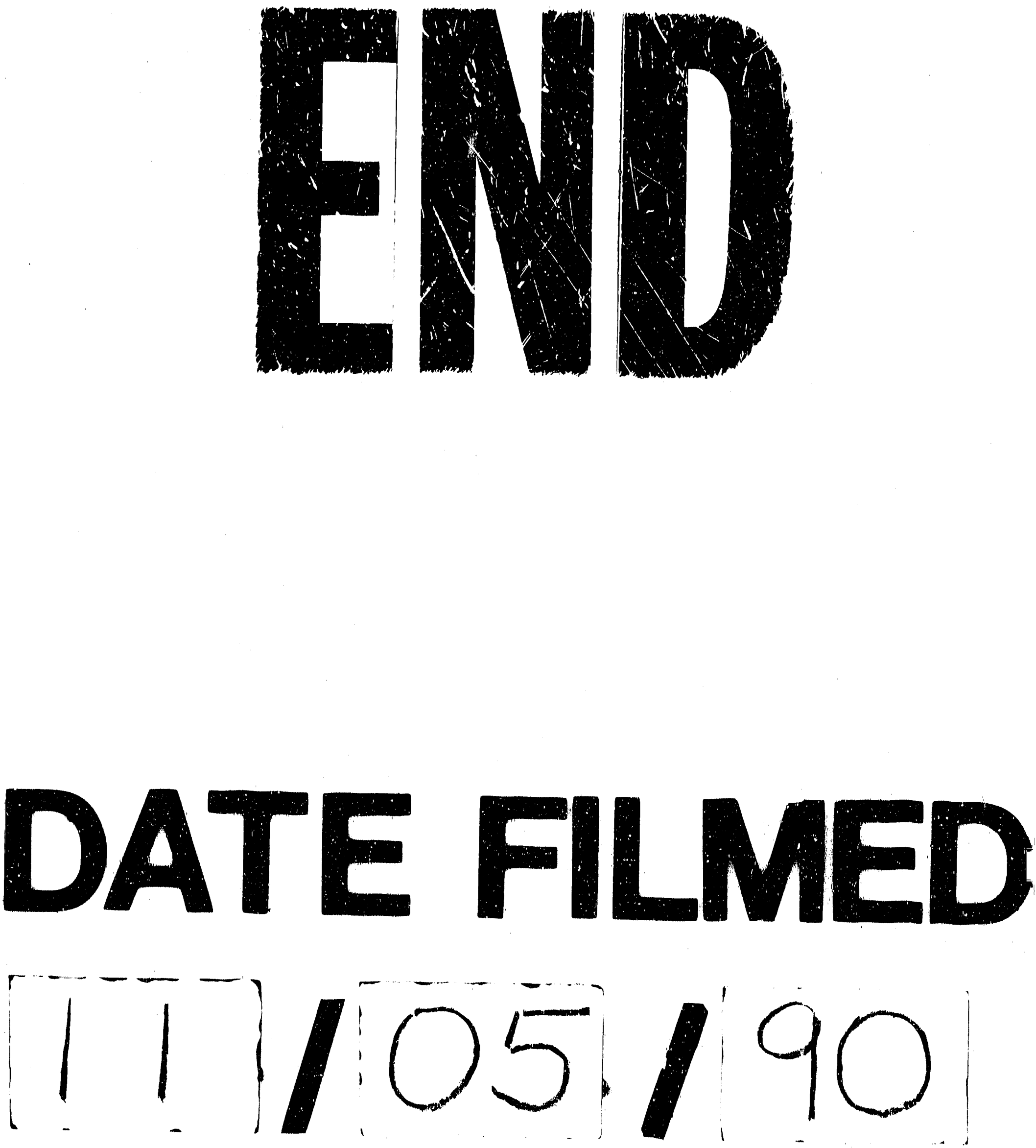
